

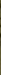
RARY OF THE UNIVERSITY OF GALIFORNIA

LIBRARY OF T
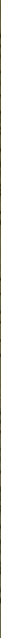

\section{RARY OF THE UNIVERSITY OF GALIFORNIA}

LIBRARY OF T

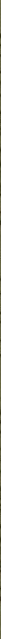




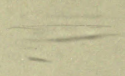




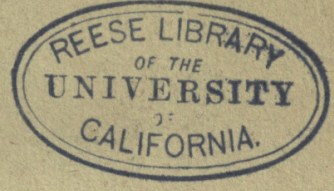




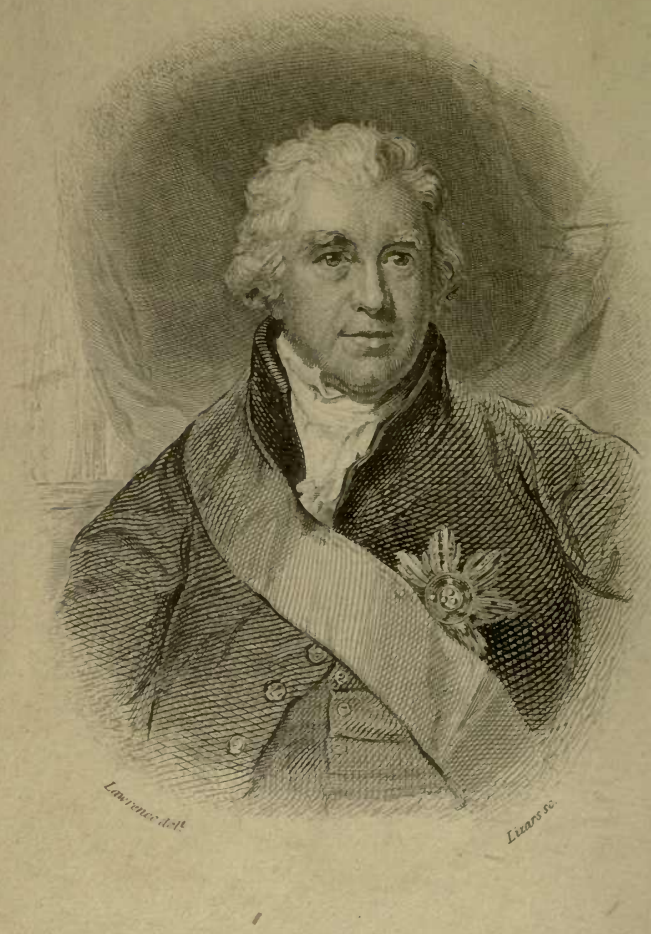

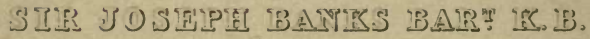


TPE

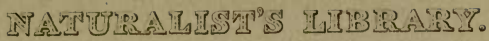

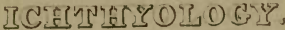

CDF OF HOW $\mathrm{HO}_{\mathrm{P}}$

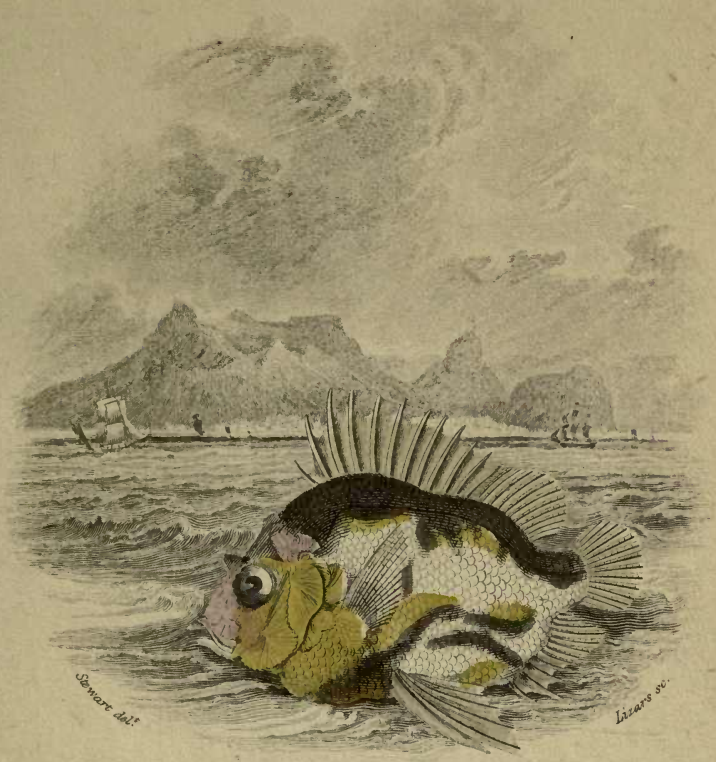

Pentaceros Capensis

Native of Cane of Good Hope.

LONDON HENRY G BOHN 
REESE LIBRARY
OF THE
UNIVITR ERITY
CALIFORNIA. 
THE

\section{NATURALIST'S LIBRARY.}

EDITED BY

SIR WILLIAM JARDINE, BART.,

F.R.S. B., F.L. s., RTC., RTC.

VOL. XXXVIII.

I C H T H Y O L O G Y.

FISHES OF THE PERCH FAMILY.

BY THE EDITOR.

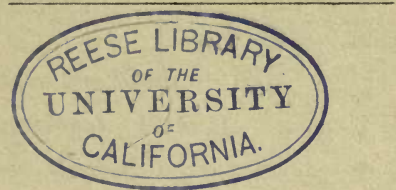

EDINBURGH :

W. H. LIZARS, 3, ST. JAMES' SQUARE.

LONDON :

HENRY G. BOHN, YORK ST., COVENT GARDEN. 


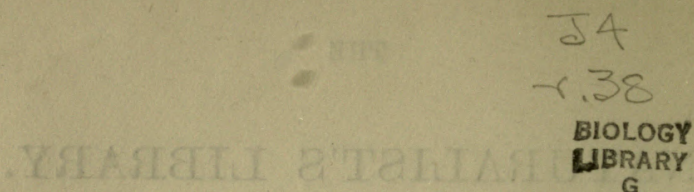
G

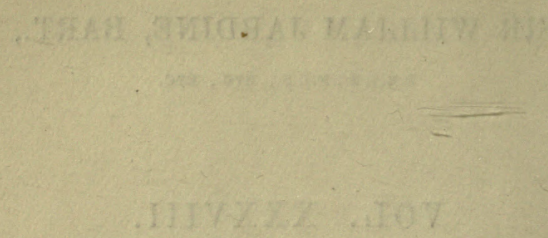
$\therefore-28690$

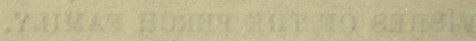

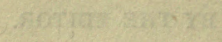

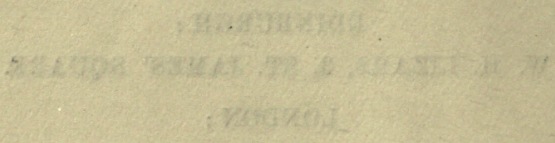




\section{CONTENTS.}

Memoir of Sir Joseph Banks . . . 17

ICHTHYOLOGY -Introduction . . . 49

Genus Perca-Perch : . . . . 91

The Granulated Perch.

Perca granulata.' Plate I. $\quad$. 92

- Ciliata . . . . . . 93

-Italica $\quad \cdot \quad \cdot \quad \cdot \quad . \quad$. 95

-labrax . . . . . 96

The Basse or Sea Perch.

Labrax lupus. Plate II. • . - 98

— lineatus . . . . . 99

The Lates of the Nile.

Lates Niloticus. Plate 111. . . 101

- nobills . . . . . 102 
Eleven-Spined Centropome.

Centropomus undecimalis. Plate IV. . 103

The Common Pike-Pureh.

Lucioperca sandra. Plate V. . • 105

- marina . . . . 107

- Americana . . . . ib.

The Black Bass of the Huror.

Huro nigricans. Plate VI. . . . 108

The Ruby-Coloured Etelis.

Etelis carbunculus. Plate VII. $\quad . \quad$. 110

The Spined Niphon.

Niphon spinosus. Plate VIII. . . . . 111

The Armed Enoplossus.

Enoplossus armatus. Plate JX. ․ . 112

''wo Banded Diploprion.

Diploprion bifasciatum. Plate X. .

115

The Mediterranean Anngon.

Apogon rex Mullorum. Plate X1. $\quad$. 117 


\section{CONTENTS.}

Apogon trimaculatus

- quadrifaciatus

- ib.

novemfaciatus

$1 \mathrm{~b}$.

Arabian Cheilodipterus.

Cheiludipterus Arabicus. Plate XII. .

. 120

quinquelineatus

12।

The Large-Eyed Pomatome.

Pomatomus telescopium. Plate XIII. . . 12.

- Commerson's Ambassis.

Ambassis Commersoni. Plate XIV.

- nama

- baculis . . . . $\mathrm{ib}_{\text {, }}$

- ranga . . . . $\mathrm{ib}_{\text {, }}$

The Zingel.

Aspro vulgaris. Plate X V. $\quad . \quad 127$

The Oriental Gramistes.

Gramistes orientalis. Plate XV1.

. 129

Perches with a Single Dorsal Fin . . . . 131

Lettered Serranus.

Serranus scriba. Plate XVII. . 
The Spined Serranus.

Serranus anthias. Plate XVIII. . $\quad 135$

- tonsor $\quad$ - $\quad$.

- oculatus . . . . . ib.

-

The Long Tailed Serranus.

Serranus photon. Plate XIX. .- . 138

Large Finned Serranus.

Serranus altivelis. Plate XX. 139

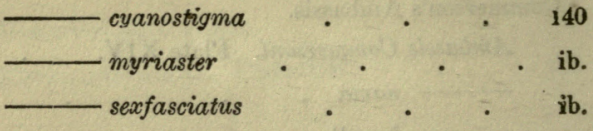

Leopard-Spotted Plectropoma.

Plectropoma leopardinus. Plate XXI. 14s

Beautiful Plectropoma.

Plectropoma puella. Plate XXII. . . 143

Banded Diacope.

Diacope rivulata. Plate XXIII. . . 145

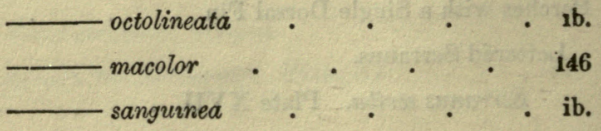


One Spotted Mesoprion.

Mesoprion uninotatus. Plate KXIV. - 148 vivanus

Golden-Tailed Mesoprion.

Mesoprion chrysurus. Plate XXV. $\quad 150$

The Ruffe.

Acerina cernua. Plate XXVI.

. 151

Many-Spined Polyprion.

Polyprion cernium. Plate XXVII. . 153

American Black Bass.

Centropristes nigricans. Plate XXVIII. . 156

- scorpenoides . $\quad . \quad . \quad 157$

- truttaceus . . . . . ib.

The Salmon-Formed Growler.

Grystes salmoides. Plate XXIX.

158

The Brazilian Rypticus.

Rypticus arenatus. Plate XXX. , 160

Genus Cirrhites . . . . . 161

Chironemus Georgianus . . . . . 162 


\section{Pomotis}

PAGE

Labrus auritus

162 Aphredoderus .

- ib.

Centrarchus

Priacanthus

Dules

Dules auriga

Dules marginatus

Therapon

Datnia

Caius Datnia .

Pelates

Helotes.

Trichodon

T. Stellerï

Sillago

Myripristis

Helocentrum

Beryx .

Trachichtys

Trachinus

Percis

Pinguipes

Percopis

Uranoscopus

Sphyroena . 


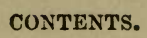

xiii

PAGE

Paralepis . . . . . 170

Polynemos $\quad . \quad$. $\quad . \quad$. 171

ihe Mullets . . . . . . ib.

Muius, Linn.-Mugil of the Ancients . - ib.

Jpenus . . . . . 172

Muscles of the Common Perch. Plate XXXI. 61

Skeleton of the Common Perch. Plate XXXII. 62

rossils.

Lates graciles. Plate XXXIII. $\quad$. 174

Lates Macrourus . . . . _ ib.

Yyclopoma spinosum. Plate XXXIV. $\quad 175$

\section{A PPE NDIX.}

Extracts from the Complete Angler of Izaac Walton, containing Observations on the Perch and Directions how to fish for him. With his Short Discourse, by way of Postscript, touching the laws of Angling • 181 Continuation of the Discourse. By Sir John Hawkins

Common Perch. Plate XXXV. . . 180

Portrait of Sir Joseph Banks

Vignette, Title Page.-Pentaceros capcnsis

In all, Thirty-Seven Plates in this Volume. 
atoial

4.25

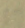

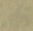

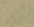

30

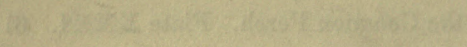

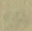

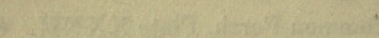

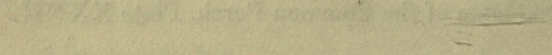

(2) -2

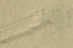

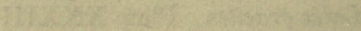

sis

32,5

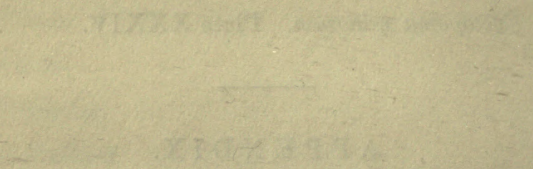

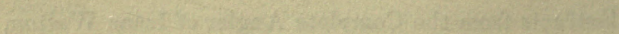

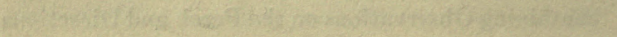

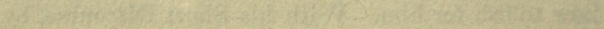

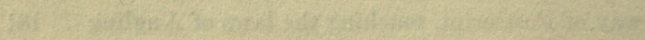
4.

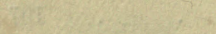

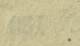

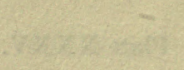

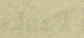

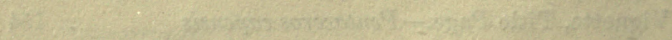

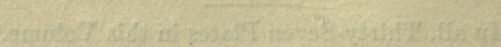




\section{E M O I R}

$$
\text { or }
$$

SIR JOSEPH BANKS. 



\section{E MOIR}

OP

\section{SIR JOSEPH BANKS.}

\section{REESE LIBRAAP \\ UNITERSITY}

CALIERNIA.

ALTHOUGH we cannot claim forthe subject of our present memoir that exalted rank as a practical naturalist, by which Linnæus and Cuvier have been distinguished, though as an author he may be said to be almost unknown; yet there have been few men in this country to whom physical science is more beholden, as his whole life was devoted to the encouragement, and his-ample fortune to the illustration of it in all its branches. He lived before the taste for natural history had become generally diffused, and it was his pride and his delight to give it that fostering protection it required in his day, from the wealthy and the noble. At the present time, when a society exists for the promotion of each department of natural history, when London, Dublin, and Edinburgh, \&c., boast of zoological collections, and a botanic garden, a museum,

rou. $x x x v i r$. 
and a lecture room, are attached to most of our provincial towns, we can scarcely appreciate the merits of an individual who set the bright example before us, and contributed in so great a degree to produce this gratifying result. Let the present generation, who reap the benefit of his exertions, not ungratefully forget the memory of Sir Joseph Banks.

His father was William Banks Hodgkinson, * Esq. the proprietor of Revesby Abbey, in Lincolnshire, where his only son Joseph was born, February 13, 1743. He received the rudiments of education at home, under a private tutor, and afterwards went to Harrow, from thence to Eton, and finally completed his studies at Christchurch, Oxford. He had the misfortune to lose his father at the early age of eighteen. It is greatly to his honour, that, thus left

Lord of himself, that heritage of wo,

there was no alteration in his habits of study, and that he resisted the allurements of youth, wealth, and freedom from parental control, for the quiet enjoyments of science. Natural history appears

* He assumed the surname and arms of Hodgkinson in compliment to his maternal grandfather. He married Sarah, daughter of William Bete, Esq. who died August 27, 1804. Besides the subject of this memoir, they had one daughter, who died unmarried, September $27,1818$. 
to have occupied his ardent miud, and botany, in particular, to which public attention had been excited through the recent publication of the Linnæan system in England, was his favourite pursuit. The gardens of Lee and Kennedy, at Hammersmith, supplied him with foreign plants, and his own industry and research for British specimens completed his practical instruction in this fascinating and exhilarating department of study.

Soon after he left the university, his friend Lieutenant Phipps, afterwards Earl of Mulgrave, being ordered with a ship of war to protect the Newfoundland fisheries, Mr Banks gave the earliest proof of his eager desire for knowledge, by sacrificing the advantages and comforts of his station as a wealthy landed proprietor just coming of age, and accompanying his friend on his voyage to this inhospitable climate. The stern realities of privation and danger with which he thus became acquainted, however interesting in the narrative, were calculated to check the ardour of a young man of independent fortune, and it might reasonably have been expected that he would have rested satisfied with this first attempt, and have henceforth been content with the reports of others ; but this was far from the case. They daunted not the inquiring mind of $\mathrm{Mr}$ Banks, for he no sooner heard of the expedition that government were about to fit out for the South 
Seas, under the command of Lieutenant Cook, than he intimated to his neighbour, Lord Sandwich, then first Lord of the Admiralty, with whom he was in the habit of enjoying aquatic sports on Whittlesea Mere, his desire to be permitted to join the expedition. This was readily acceded to, and $\mathrm{Mr}$ Banks determined to spare no expense in availing himself of the advantages that were thus opened before him. He, therefore, engaged the celebrated Dr Solander,* the friend and pupil of Linnæus, at a salary of $£ 400$ per annum, during the voyage; together with Mr Sydney

- Of the wisdom of this choice, Dr Pulteney's character of Solander is a proof. He says, "At this juncture, it is material, among those circumstances which accelerated the progress of the new system, (the Linnæan,) to mention the arrival of the late much lamented Dr Solander, who came into England on the first of July, 1760. His name, and the connection he was known to bear as the favourite pupil of his great master, had of themselves some share in exciting a curiosity, which led to information; whilst his perfect acquaintance with the whole scheme enabled him to explain its minutest parts, and elucidate all those obscurities with which, on a superficial view, it was thought to be enveloped. I add to this, that the urbanity of his manners, and his readiness to afford every assistance in his power, joined to that clearness and energy with which he effected it, not only brought conviction of its excellence in those who were inclined to receive it, but conciliated the mind, and dispelled the prejudices of many who had been averse to it." - Sketches of the Progress of Botany, vol. ii. p. 350 . 
Parkinson and $\mathrm{Mr}$ Buchan as draughtsmen; a private secretary, and four servants, two of whom were negroes. Thus prepared, the party went on board his Majesty's ship Endeavour, which left Deptford, July 30, 1768; and, having been detained at Plymouth for some time, finally put to sea on Friday, August 26.

This is not the place to enter into minute particulars of the voyage; but it will be necessary to notice some of the personal adventures of $\mathbf{M r}$ Banks. On Saturday, January 14, 1769, they entered the Straits of Le Maire, and landed at Terra del Fuego, where they collected numerous specimens of plants unknown to Europeans ; and on Monday, the 16th, Mr Banks, accompanied by Dr Solander, made a botanical excursion to the more elevated regions, in the expectation of a rich harvest of Alpine plants, intending to return to the vessel at night; but, from intense cold, and frequent snow storms, they were too much fatigued to attempt it, and were compelled to remain all night exposed to the rigour of the climate. Dr Solander, who, from having crossed the mountains which divide Sweden from Norway, was aware of the dangers arising from that torpor and inclination to sleep, produced by extreme cold and fatigue, warned the party to keep moving, for whoever sat down would sleep, and whoever slept would wake no more. It was casier, 
however, to give the advice than to resist the inclination, for the Doctor himself was the first to violate the injunction, and had it not been for the energy, intrepidity, and resolution of $\mathrm{Mr}$ Banks, he would have fallen a victim to his indiscretion. By his exertions he was at length removed to a place where they had succeeded in kindling a fire. "Here they passed the night in a situation, which, however dreadful in itself, was rendered more afflicting by the remembrance of what was past, and the uncertainty of what was to come. Of twelve, the number that set out together in health and spirits, two were supposed to be already dead; a third was so ill that it was very doubtful whether he would be able to go forward in the morning ; and a fourth, Mr Buchan, was in danger of a return of his fits* by fresh fatigue, after so. uncomfortable a night. They were distant from the ship a long day's journey through pathless woods, in which it was too probable they might be bewildered, till they were overtaken by the next night ; and, not having prepared for a journey of more than eight or ten hours, they were wholly destitute of provisions, except a vulture, which they happened to shoot while they were out, and which, if equally divided, would not afford

- Mr Buchan was one of Mr Banks's draughtsmen. He was subject to epileptic fits, and died at Otaheite, on the 17 th of April. 
each of them half a meal ; and tney knew not how much more they might suffer from the cold, as the snow still continued to fall." * At daybreak, how . ever, after having cut up their vulture into ten portions, and given every man his share to cook in his own way, they prepared to set out, and providentially found thernselves nearer to the beach than they expected, for they had made a circuit of the hill. They thus succeeded in reaching the vessel by mid-day, with the exception of two of the party, a seaman and a negro, who died.

We have selected this adventure as a proof of the ardour with which $\mathrm{Mr}$ Banks entered on the duties he had volunteered, and the courage and perseverance with which he at all times pursued the objects of the expedition. Indeed, he must have been a most valuable assistant to Lieutenant Cook during the whole of his arduous and responsible undertaking, for he appears never to have shrunk from services of danger; but, on the contrary, to have taken the lead on all emergencies. We will give another instance of great fortitude, by which a principal object of the voyage was secured from defeat.

It is well known, that to observe the transit of Venus over the sun's disk, from some of the islands of the South Seas, was the purpose for which the Endeavour was primarily fitted out, in

- Hawkesworth. 
consequence of a memorial being presented to his Majesty from the Royal Society; and, for this purpose, an observatory had been erected at Otaheite, where the ship had arrived on the 13th of March. But, on the morning of the $2 d$ of May, on going to fix the quadrant for use, it was found to have been stolen. In this dilemma, Mr Banks volunteered to go in search of it; and, in company with $\mathrm{Mr}$ Green, the astronomer, and unarmed, except with a pair of pocket pistols, they proceeded to the interior of the country, to demand its restitution. In this delicate mission they were happily successful. When they arrived at the place to which they had been directed, they met one of the natives " with part of the quadrant in his hand. At this most welcome sight they stopped ; and a great number of Indians immediately came up, some of whom, pressing rather rudely upon them, Mr Banks thought it necessary to shew one of his pistols, the sight of which reduced them instantly to order. As the crowd that gathered round them was every moment increasing, he marked out a circle in the grass, and they ranged themselves on the outside of it, to the number of several hundreds, with great quietness and decorum."* Here, after some little difficulties, the stolen property was restored, and

- Hawkesworth. 
thus, by the presence of mind and prudence of Mr Banks, the instrument was recovered without disturbing that harmony with the natives, so essential to the objects of the navigators.

Another anecdote of $\mathrm{Mr}$ Banks displays his enthusiasm in obtaining the most correct information as to the manners of the people amongst whom he had become a resident. He had a great desire to see a funeral procession, but was told his only mode of doing so with propriety, was to take a part in it, which he determined to do ; and, for this purpose, he was stripped of his clothes, and a piece of cloth being tied round his middle, his body was smeared with charcoal and water; and in this guise he joined the procession. It is needless to give other instances of Mr Banks's zeal : they might be multiplied to an indefinite extent. Cook paid him the well merited compliment of naming after him one of the newly discovered Islands of New Zealand, lying in latitude $43^{\circ} 32^{\prime}$ south, and in longitude $186^{\circ} 30^{\prime}$ west.

At New Holland, while the ship was undergoing repairs, the world had nearly been deprived of the labours of this enterprising naturalist. In order to secure his collections, and preserve them with more than ordinary care, he had removed them to the bread room; but the workmen, in their necessary repairs of the vessel, threw her so much abaft, that her stern was filled with water, by 
which many of his specimens were entirely destroyed. The greater part, however, by great care and attention, were restored. There was now every appearance of a successful termination to their voyage, when the discovery of the very defective state of the ship obliged them to stay at Batavia. Here a scene of horror occurred, from which the heart recoils. The whole crew were in a few days seized with illness, arising from the pestilential air of the country, neither Mr Banks nor Dr Solander excepted. They were both pronounced so ill, that there was no chance for recovery, except by a removal to a country house, which was procured for them about two miles from town. Here, after much suffering, they slowly recovered. They set sail from this den of pestilence December 26, 1770, having buried there the surgeon, and six others. Forty of the crew were in a state of extreme disease.

\section{Despair}

Tended the sick, busiest from couch to couch ; And over them, triumphant, Death his dart Shook.

Twenty-three of these miserable beings died on their passage to the Cape, among whom were two of Mr Banks's retinue, namely, Mr Parkinson, the natural history painter, and Mr Sporing. The remainder reached the Cape, March 15, 1771 ; 
and, after a safe voyage from thence, they landea at Deal, Wednesday, June 12, having been absent three years.

One very important consequence of this voyage, and which was brought about chiefly by the influence of $\mathrm{Mr}$ Banks, was the introduction, in 1793, of the Bread Fruit Tree (Artocarpus incisc, and Artocarpus integrifolia) into the West Indies. It is a native of the South Sea Islands. In reference to this event, Bryan Edwards observes: "Among all the labours of life, if there is one pursuit more replete than any other with benevolence, more likely to add comforts to existing people, and even to augment their numbers by augmenting their means of subsistence, it is certainly that of spreading abroad the bounties of creation, by transplanting from one part of the globe to another such natural productions as are likely to prove beneficial to the interests of humanity. In this generous effort Sir Joseph Banks has employed a considerable part of his time, attention, and fortune; and the success which, in many cases, has crowned his endeavours will be felt in the enjoyments, and rewarded by the blessings of posterity." *

At his return, Mr Banks was received with enthusiasm by all ranks. He had been some time

- History of the West Indies. 
a member of the Royal Society; and, during the short time he remained at home, he took an active part in their proceedings. Government were so well satisfied with the results of Lieutenant Cook's first voyage that he received a captain's commission, with instructions to take the command of an expedition on a larger scale, which was to sail the following year. Mr Banks fully intended to have again accompanied him, and expended several thousand pounds for instruments and other preparations for the voyage, when an unfortunate dispute with the Navy Board disgusted him, and he abandoned the idea; but having again engaged the services of Dr Solander and other scientific gentlemen, he determined to explore Iceland, at that time very little known. For this purpose he chartered a vessel, at an expense of $£ 100$ per month, and left London the 12th July, 1772. The party consisted of Dr Solander, Dr Von Troil, another Swedish naturalist, Dr. Lind of Edinburgh, as astronomer, Lieutenant Gore, who had sailed with him round the world, three draughtsmen, two amanuenses, with servants and seamen to the number of forty people. Having visited the Western Islands of Scotland, they were forced; on the night of the 12th of August, to cast anchor in the sound between Mull and Morvern, opposite to Drumnen, the seat of Mr M'Lean. They were immediately invited to land. During breakfast, 
next morning, the conversation turned upon the island of Staffa, which another guest of M'Lean, an Englishman of the name of Leach, had been visiting a few days before. His account stimulated the curiosity of the new visiters, whom he politely offered to accompany to the spot. This was eagerly accepted. Previous to this visit, this magnificent specimen of "nature's architecture" had never been examined by scientific observers, and was scarcely known beyond its immediate neighbourhood. $\mathrm{Mr}$ Banks took a minute survey of the whole, with measurements and drawings of he basaltic columns, and transmitted his account to Pennant, who printed it in his Tour to Scotland, which had been made the same year. Dr $\mathrm{M} \cdot \mathrm{Culloch}$ has more recently described this celebrated wonder, which is now familiar to every one. His measurements differ from those of his predecessor, and are probably more accurate.

On the 28th of August they arrived at Iceland, and cast anchor at Bessestedr, on the western part of the island, where the dismal appearance of the country alarmed them. "Imagine to yourself," says Von Troil, "a country which, from one end to the other, presents to your view only barren mountains, whose summits are covered with eternal snow, and between them fields, divided by vitrified cliffs, whose high and sharp points seem to vif with each other to 
deprive you of the sight of a little grass whicn scantily springs up among them. These same dreary rocks likewise conceal the few scattered habitations of the natives, and no where a single tree appears which might afford shelter to friend. ship and innocence. The prospect before us, though not pleasing, was uncommon and surprising. Whatever presented itself to our view bore the marks of devastation, and our eyes, accustomed to behold the pleasing coasts of England, now saw nothing but the vestiges of the operation of a fire, Heaven knows how ancient." This exclamation was merely the effect of the contrast alluded to. It was precisely the situation adapted to their inquiries; and, to a mind like Mr Banks's, intent on exploring the wonders of Nature on a most magnificent scale, such a scene must have been fraught with peculiar attractions. The following account of their visit to the great Geyser will be read with interest. "Among the many hot springs to be met with in Iceland, several bear the name of Geyser.* The following is a description of the most remarkable of that name, and in the whole island. It is about two days' journey from Hecla, near a farm called Haukadul. Here a poet would have an opportunity

- From the Icelandic geysa, to rage, burst forth witb vehemence and impetuosity. 
of painting whatever Nature has of beautiful and terrible united in one picture, by delineating this surprising phenomenon. Represent to yourself a large field, where you see on one side, at a great distance, high mountains covered with ice, whose summits are generally wrapped in clouds, so that their sharp and unequal points become invisible. This loss, however, is compensated by a certain wind, which causes the clouds to sink, and cover the mountain itself, when its summit appears as it were to rest on the clouds. On the other side Hecla is seen, with its three points covered with ice, rising above the clouds, and with the smoke which ascends from it, forming other clouds, at some distance from the real ones; and, on another side is a ridge of high rocks, at the foot of which boiling water, from time to time, issues forth; and farther on extends a marsh of about three English miles in circumference, where are forty or fifty boiling springs, from which a vapour ascends to a prodigious height. In the midst of these is the greatest spring, Geyser, which deserves a more exact and particular account. In travelling to the place, about an English mile and a-half from the hver, from which the ridge of rock still divided us, we heard a loud roaring noise, like the rushing of a torrent precipitating itself from stupendous rocks. We asked our guide what it meant; he answered it was Geyser 
roaring; and we soon saw with our naked eyes what before seemed almost incredible. The depth of the spring, or pipe from which the water gushes, cannot well be determined ; for sometimes the water sank down several fathoms, and some seconds passed before a stone, which was thrown: into the aperture, reached the surface of the water. The opening itself was perfectly round, and nineteen feet in diameter, and terminated in a basin fifty-nine feet in diameter. Both the pipe and the basin were covered with a rough stalactitic rind, which had been formed by the force of the water; the outermost border of the basin is nine feet and an inch higher than the pipe itself. The water here spouted several times a-day, but: always by starts, and after certain intervals. The: people who lived in the neighbourhood told us that they rose higher in cold and bad weather than at other times, and Egbert Olafsen, and others, affirm that it has spouted to the height of sixty fathoms. Most probably, they guiesised only by the eye, and. on that account their calculation may be a little extravagant; and, indeed, it is to be doubter whether the water was ever thrown up so high, though, probably, it sometimes mounts higher than when we observed it. The method we took to observe the height was as follows. Every one in company wrote down, at each time that the water spouted, how high it appeared to him to be 
thrown, and we afterwards chose the medium. The first column marks the spoutings of the water, in the order in which they followed one another; the second, the time when these effusions happened; the third, the height to which the water rose; and the last, how long each spouting of water continued.

\begin{tabular}{|c|c|c|c|}
\hline & Time. & Height. & Duration \\
\hline No. 1 at & 642 A.M. & 30 feet. & 020 seconds. \\
\hline 2 & 651 & 6 & 020 \\
\hline 3 & 716 & 6 & 010 \\
\hline 4 & 731 & 12 & 015 \\
\hline 5 & 751 & 60 & 06 \\
\hline 6 & $\begin{array}{lll}8 & 17\end{array}$ & 24 & 030 \\
\hline 7 & 829 & 18 & 040 \\
\hline 8 & 836 & 12 & 040 \\
\hline
\end{tabular}

The pipe was now, for the first time, full of water, which ran slowly into the basin.
9 . $\quad 925$
48
110
$10 \quad 10 \quad 16$
24
10

2. thirty-five minut es after twelve, we heard as it were three discharges of a gun under ground, which made it shake; the water flowed over immediately, but instantly sank again. At eight minutes after two, the waters flowed over the border of the basin; at fifteen minutes after three, we again heard several subterranean hoises, though not so strong as before; at forty-three minutes 
after four, the water flowed over very strongly during the space of a minute; in six minutes after, we heard many loud subterraneous discharges, not only near the spring, but also from the neighbouring ridge of rocks, where the water spouted; at fifty-one minutes after six, the fountain spouted up to the height of ninety-two feet, and continued to do so for four minutes. After this great effort it sank down very low into the pipe, and was entirely quiet during several minutes, but soon began to bubble again; it was not, however, thrown up into the air, but only to the top of the pipe.* The force of the vapours which throw up these waters is excessive : it not only prevents the stones which are thrown into the opening from sinking, but even throws them up to a very great height, together with the water. When the basin was full, we placed ourselves

- From observations that have been made at different periods, it appears that the height of the jets is very irregular. In Olafsen's time it is stated to have been three hundred and sixty feet. The highest above stated, in 1772, was ninety-two feet. Sir John Stanley, in 1789, gives ninety-six feet; ' Lieutenant Ohlson, a Danish officer, found, by a quadrant, that the highest jet ran, in 1804, to two hundred and twelve feet; Mr Hooker, in 1809, mentions one hundred feet; and Sir George M'Kenzie, in 1810, states it to have been ninety feet. Henderson, in July, 1814, saw it vary from sixty to a hundred feet, and again, in August, 1815, it was one hundred and fifty feet. 
before the sun in such a manner that we could see our shadows in the water; when every one observed, round the shadow of his own head, (though not round that of the heads of others,) a circle of almost the same colours which compose the rainbow, and round this another bright circle. This most probably proceeded from the vapours exhaling from the water. Not far from this place, another spring, at the foot of the neighbouring ridge of rocks, spouted water to the height of one or two yards each time. The opening through which this water issued was not so wide as the other. We imagined it possible to stop up the hole entirely by throwing large stones into it, and even flattered ourselves that our attempts had succeeded; but, to our astonishment, the water gushed forth in a very violent manner. We hastened to the pipe, and found all the stones thrown aside, and the water playing freely through its former channel. In these large springs the water was hot in the highest degree, and tasted a little of sulphur; but, in other respects, it was pure and clear. In the smaller springs of the neighbourhood the water was tainted; in some, it was as muddy as that of a clay pit; in others, as white as milk; and in some few, as red as blood."*

- Von Troil, page 256. 
The hot springs were thus examined; the volcanoes, diseases, government and laws, the literature, and manners and customs of the inhabitants, were all eagerly inquired into. Numerous curiosities of all kinds were purchased and brought to this country, which they reached in safety in November; and Mr Banks presented to the British Museum no less than one hundred and sixty-two Icelandic manuscripts, which he had procured at his own expense. Many years afterwards, the inhabitants of. Iceland received a grateful testimonial of the interest they had excited in the bosom of the travellers; for, on the breaking out of the war between Great Britain and Denmark in 1807, the Icelanders were apprehensive of starvation, from the customary supplies from the mother country being intercepted by our ships of war. Sir Joseph Banks, however, not forgetful of his old friends, humanely exerted himself, and, by his interest with his Majesty's Government, procured licences for Danish vessels to proceed to Iceland on condition of their touching at the port of Leith, and subsequently procured an Order in Council, dated February 7, 1810 , prohibiting all acts of hostility against Iceland, and the rest of the Danish colonies in the Arctic Seas, and taking the inhabitants, and their property, under the special protection of Great Britain. 
This voyage terminated his foreign travels, and for some years Mr Banks passed his time between his Lincolnshire property and his house in London, where he formed a splendid library, with a valuable and extensive collection of natural curiosities. He corresponded with the celebrated men of all countries, and was looked up to as a proper person to preside over the Royal Society. They had for some time been embroiled in party disputes, which led to very acrimonious feelings on both sides, and finally to the resignation of Sir John Pringle, on St Andrew's day, 1778, when Mr Banks was elected president in his room. There was at the time much difference of opinion as to the propriety of this selection. It was objected that he had not sufficiently distinguished himself as an original discoverer, or even improver, in any branch of science. For the first few years he had many opponents, but the suavity of his manners, and the zeal with which he pro. secuted the objects and interests of the Society, finally triumphed over his adversaries.

On the 29th March, 1779, he married Dorothea, daughter and co-heiress of William Weston Huguesson, Esq. of Provender, in the parish of Norton, in Kent, with whom he lived happily many years. They had no children, but this lady survived him, dying on the 28th of June, 1828. In 1781, the King, with whom he had become a 
favourite, conferred the dignity of a baronet upon hìn, and many years after distinguished him by the Order of the Bath, at that time a very rare honour to a civilian, and he was subsequently sworn a member of his Majesty's Privy Council.

In the meanwhile, his situation at the Royal Society was by no means an easy or an enviable one. The celebrated Dr Horsley (afterwards Bishop of St Asaph) headed a party who were attached to the study of the abstract sciences, and partly from jealousy of the attention that was paid to natural history, and probably equally jealous of the aristocratic members, whom it was insinuated that the president had introduced to the Society from no other qualification than their rank, he threatened secession in the following energetic speech :- "If other remedies fail, we can at least secede. When the hour of secession comes, the president will be left, with his train of feeble amateurs, and that toy upon the table, the ghost of that society in which philosophy once reigned, and Newton presided as her minister." Finding himself not supported in his views, he did actually withdraw, with some others, and left Sir Joseph to the peaccable and undisturbed possession of the chair for nearly forty years.

He now assumed that rank in the literary and scientific world becoming his station, as the head of so illustrious a body. His house in Soho Square 
was open to all who were distinguished by talents, of every country. His library was accessible to every one engaged in kindred pursuits; and, to render it more generally useful, an arranged catalogue of it was published, and most generously distributed in all quarters where it was likely to be of service. It was commenced in 1796, and completed in 1800. Its title and arrangement are as follows :- "Catalogus Bibliothecæ Historico Naturalis Josephi Banks, Regi a Consiliis Intimis, Baronetti, Balnei Equitis, Regiæ Societatis Presidio, \&c. Auctore Jona Dryander, A.M. Regio Societatis Bibliothecario."

Tomus 1. Scriptores Generales, Londini 1798 Tomus 2. Zoologici, _ _ _ _ $\quad 1796$ Tomus 3. Botanici, • • . 1797 Tomus 4. Mineralogi, $\quad$. $\quad$. 1799 Tomus 5. Supplementum et Index Auctorum, 1800

The books are methodically classed, and numerous references are made to the authors of memoirs and papers, in all the Transactions of the learned societies throughout Europe, America, and the East. The number of pages and plates in the respective volumes being indicated in the catalogue, renders it particularly valuable. The library is rich in German, Swedish, and other northern writers, which are extremely rare in this country Among the scarce English books, there are the first edition of Izaak Walton's " Complete Angler, 
or the Contemplative Man's Recreation." London, 1653, small octavo; and a work published by John Earl of Bute, of which his Lordship printed only sixteen copies for private distribution. It is entitled "Botanical Tables, containing the different Families of British Plants, distinguished by a few obvious parts of fructification, ranged in a synoptical method; some observations on the terms employed in Botany, and particularly on those borrowed from the anatomical descriptions of animals; and a glossary explaining botanical terms, with numerous figures." 9 vols. 4 to.

While thus in the enjoyment of wealth, rank, fame, literary society, and the personal esteem of his sovereign, a circumstance occurred that had nearly occasioned him to forfeit the latter, and which also deeply offended many of his friends in the Royal Society. In January, 1802, the National Institute of France having been new modelled, elected and placed him at the head of their Foreign Associates, a compliment the greater, that their number was limited to eight. Sir Joseph naturally felt proud of the honour, and expressed his gratitude in the following letter:

"London, January 21, 1802.

"Citizens,-Be pleased to offer to the National Institute my warmest thanks for the honour they 
have done me in conferring upon me the title of Associate of this learned and distinguished body. Assure, at the same time, my respectable brothers, that I consider this mark of their esteem as the highest and most enviable literary distinction which I could possibly attain. To be the first elected to be an associate of the first Literary Society in the world, surpasses my most ambitious hopes; and I cannot be too grateful towards a society which has conferred upon me this honour, and towards a nation of which it is the literary representative a nation which, during the most frightful convulsions of the late most terrible revolution, never ceased to possess my esteem; being always persuaded, even during the most disastrous periods, that it contained many good citizens, who would infallibly get the upper hand, and who would re-establish in the hearts of their countrymen the empire of virtue, of justice, and of honour.

" Receive more especially, citizens, my warmest acknowledgments for the truly polite manner in which you communicated this agreeable intelligence. I am, with sincere esteem for your distinguished talents, \&c. Joseph BANks."

That this letter was hyperbolically worded, there can be but one opinion. But a candid allowance might be made for the enthusiasm of the moment; and it would probably have excited little 
observation, had not his old antagonist, Bishop Horsley, seized on it with avidity, and commented on It with much bitterness in a letter addressed to its author, which he printed, and privately circulated, under the signature of Misogallus. The King, (George III.) who sometimes suffered his political feelings to govern his conduct, even in the decision of a scientific question, and who had taken offence at Sir John Pringle (Sir Joseph's predecessor in the chair of the Royal Society) for countenancing Franklin's lightning conductors, was deeply offended at these expressions of " esteem" for a republican institution. His Majesty's anger had, no doubt, been excited by the remark of Horsley, that the letter "was replete with sentiments which were a compound of servility, disloyalty, and falsehood ; sentiments which ought never to be conceived by an English heart, never written by an English hand, and least of all, by yours, distinguished as you are by repeated (out of respect to his Majesty I will not say unmerited) marks of royal favour." The ire of the Royal Society was provoked by the following passage of Horsley's letter : - "It was reserved for the head of the Royal Society of London to assure an exotic embryo academy, that he is more proud of being a mere associate of the latter than president of the former; that he considers their election of him as 'the 
highest and most enviable literary distinction which he could possibly attain,' and that he deems them the 'first literary society in the world.' Sir, I have read with pleasure and with profit many volumes published by the Royal Society, and with due submission to you, I assert that the cultivation of science is more indebted to their exertions, than to those of any other institution whatsoever; but I am yet to learn the merits of this novel association of revolutionary philosophers into which you have been enlisted. What acts, but acts of robbery, have we seen of them? Where are the proofs of their pre-eminence? It is incumbent on you to produce those proofs, and to convince the British literati that your contempt of them is just."

Whatever difference of opinion there may exist as to the terms in which the honour was acknowledged, Sir Joseph had deserved the compliment, by the liberality of his exertions in procuring the restitution of scientific collections addressed to the Jardin du Roi at Paris, which had been captured by our ships during the war with France. It is said that his intercession was no less than ten times successfully exerted in this manner. "He thought that national hostility should find no entrance among followers of science." These are traits in his character highly deserving of remembrance, and an eminent member of the Institute, in his 
eloge, has gratefully recorded it:- "Lorsque la discorde," says M. Cuvier, "eut mis fin à l'expédition d'Entrecastiaux, et que les collections de M. de la Billardiére furent transportées en Angleterre, il réussit á se les faire remettre; et non seulement il s' empressa de les renvoyer ici, il ajouta à tant de soins la délicatesse de les renvoyer sans même les avoir regardées. In auroit craint d'enlevir écrivoit il á M. de Jussieu, une seule idée botanique à un homme qui étoit allé les conquérir au péril de sa vie. Dix fois des collections adressées au Jardin du Roi, et prises, par des vaisseaux Anglais, furent recouvrées par lui et rendues de la même manière; il envoya jusqu' au Cap de Bonne Espérance pour faire relâcher des caisses appartenant á M. de Humbolt, qui avoient été prises par des corsaires, et n' a jamais voulu en recevoir le remboursment." His Majesty's anger was, however, speedily dissipated, for he had ever a particular regard for Sir Joseph, who for many years superintended the royal stock of Merino sheep, and presided at their sale by auction, which annually took place at Windsor.

Sir Joseph Banks had always been partial to agricultural pursuits, and had turned his practical knowledge to great advantage, by the draining of the Lincolnshire fens, a measure which very materially improved the value of his estates. He was 
ever a zealous promoter of the interests of the Board of Agriculture and the Horticultural Society,-not making his favourite studies a mere barren and speculative amusement, but ever ready to render them subservient to purposes of general utility. Indeed, there was no institution for the encouragement of science, or that proposed to enlarge and multiply the comforts of mankind by the diffusion of knowledge, by useful experiments, or by diligent investigation, that he did not liberally and cordially patronize. He took an active and a leading part in the formation of the African Institution; he prevailed on the Government to explore the extensive shores of New Holland; and was a strenuous supporter of the Royal Institution.

In these pursuits, and in the exercise of a generous hospitality, passed the latter days of Sir Joseph Banks. His house in Soho Square was open every Sunday evening during the winter season. The kind and attentive manner in which he discharged the duties of host, the brilliancy of his conversation, the galaxy of talented individuals he collected around him, the display of curiosities in nature and art with which the rooms were crowded, rendered these meetings an intellectual treat of no ordinary kind, the recollection of which will long survive in the memory of his friends. He latterly became a martyr to the 
gout, so much so, that he required to be lifted in and out of his carriage by two footmen. He at first tried ginger in very large quantities, until he acknowledged " he had fairly exhausted all its virtues." He then had recourse to a more questionable remedy, - the much vaunted quack medicine, the eau médicinale, but with little ultimate benefit, though he at first flattered himself it had afforded him relief. Being at length exhausted, he expired on the 9 th of May, 1820, in the 78th year of his age.

His zeal for the interests of science extended beyond his life, for in his will he devised his very valuable and extensive library and foreign correspondence to the British Museum; * his drawings of plants from the Royal Garden at Kew to that establishment; his papers respecting the Royal Society, to the Royal Society; and those respecting coinage to the Mint; and to Mr Frederic Bauer, who had for thirty years been in his employ as a botanical draughtsman, an annuity of L.300, upon condition of his continuing the series of drawings of the plants from Kew Gardens, upor

- The Banksian Library is placed in the 5 th, 6 th, and 7th rooms of the upper floor of the Museum; and in the entrance hall is a statue of Sir Joseph, by Chantrey, representing him in the vigour of youth, seated in an armchair, holding a scroll in his right hand. It was presented by his personal friends. 
which he was engaged at the time of his death. His only separate publication was a pamphlet on the blight in wheat, but there are several of his papers in the Philosophical and Horticultural Transactions. We have before alluded to his description of Staffa in Pennant's Second Tour in Scotland.

In early life Sir Joseph was tall and well proportioned, with a countenance expressive of dignity and intelligence. His manners were polite, his conversation rich in instructive information, frank, engaging, unaffected, without levity, yet endowed with sufficient vivacity. He was an accomplished gentleman, a judicious inquirer, a diligent votary, and a liberal patron of science and learning. The period of his life was one peculiarly fitted to render his talents and patronage of great importance to the advancement of natural history. The encouragement given by the Government to voyages of discovery, afforded a striking opportunity for agentleman of wealth and influence to ensure a proper attention being paid to these important subjects by taking on himself the expense of all the arrangements connected with their illustration. In addition to this no trifling advantage, Mr Banks added his own personal services. On his return, those benefits naturally placed him in a prominent point of view; and by forming at his house a repository of all that was 
curious, and collecting together persons of kindred minds, he was the means of giving an immense impetus to the progress of botany, zoology, and mineralogy, which led in a great measure to the institution of societies for the advancement of each. And it is matter of congratulation that our knowledge of Natural History has materially increased through the formation of these societies, and the improved mode of investigation by the aid of anatomy and physiology, which they have encouraged 


\section{ICHTHYOLOGY.

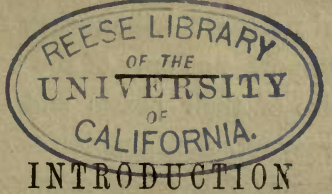

"The carp, with golden scales, in wanton play;

The trout in crimson-speckled glory gay;

The red-finn'd roach, the silver-coated eel;

The pike, whose haunt the twisted roots concear;

The healing tench, the gudgeon, perch, and bream And all the sportive natives of the stream."

THE study of fishes, technically termed Ichthyology, was, perhaps, longer in being brought to what might be called a science, than the histories and descriptions of animals and birds. The difficulty of procuring a numerous series of individuals, and the impossibility of penetrating 
and pursuing them in the deep recesses of the ocean, withdrew the constant charm, which novelty of form threw over the branches constituted by those animals which inhabited the same element with ourselves; and unless almost as a necessary article of sustenance, few fishes were taken from their proper habitations. In the earlier ages, fish were most extensively used as an article of food, and, at the present time, among several northern tribes, they form a great part of the support, not only of the natives themselves, but also of their beasts and cattle. According to Frecynet, the inhabitants of the Sandwich Isles devour fish when newly caught, and when they are scarcely dead.-(Voyage autour du Monde.) In other parts, they were the only money of the country, and dried fish were paid as a current coin. These circumstances naturally led to the distinction of the more excellent kinds-of those which were noxious when eaten, and of those which were difficult or dangerous to capture. Again, in other regions, the minds of the inhabitants assume a more serious or rather superstitious turn - they fear them as river deities, or worship them as ocean gods, carrying their enthusiasm so far as to embalm their bodies, and like the inhabitants of Java and Sumatra, in the propitiatory offerings to the tiger; those of 
the Polynesian Isles deify the large blue sharks (Sq. glaucus), and rather than attempt to destroy them, endeavour to propitiate their favour by prayers and offerings, in temples where their priests officiate.

Necessity, most probably, first induced mankind to employ fishes as an article of food, and the same grand incentive to discovery, gradually taught the most successful means and fittest weapons for securing a supply. Among the various contrivances which have been employed for taking a prey of great strength and extraordinary activity, perhaps some method of spearing or darting a sharp instrument at the fish, was the most early practised, and was exercised previous to the invention of hooks or nets. Among tribes in a state of nature, who have only the resources of their own invention, and materials of inferior quality, we still find, almost invariably, this method practised, often with very great dexterity, or with a bait sometimes affixed to the point of the weapon, as a lure to entice the fish within reach. The clear view given in the water by fire or torch light, was also early discovered, and formed a powerful and destructive accessary. Hooks became a later invention, naturally succeeding the greater experience which an intercourse with the manners of 
the animals themselves would suggest; at first, made of the rudest form and coarse materialsas shell, or bone, or hardened wood - they did their office ill, were only fitted for the larger kinds, and exhibit a striking contrast with the finely polished and tempered wire, and the beautiful material gut, now in use.

Fishing, from a pursuit of necessity, became one of emolument, and during the Greek and Roman ages, the profession of a fisherman was one of the most common and respectable; and farther intercourse and experience produced improved hooks, nets, and lines of finer quality, but equal strength, better fitted to retain and to deceive, though the older practices of spearing were still retained, accompanied with a greater array of followers, and weapons of more approved form and delicate temper. Approaching still nearer to our own times, we see hardy races of men almost solely employed in providing for the luxurious taste of the great European markets, and supplied with vessels, beautifully built, materials and weapons of the best descriptionthe fisheries, supported by governments, becoming the nurseries of seamen, and of great importance in the revenues of kingdoms.

From attention being thus necessarily and unavoidably directed towards fish, and the means 
of taking them, rude drawings were preserved of the more important kinds. They were perpetuated on the coinage of the countries, and bold bur characteristic sculptures have been preserved, from which many of the species in ancient use can be traced. Such may be said to be the commencement of Ichthyology, and so also it may be said to have progressed until the works of the illustrious Aristotle threw a light over every branch of Natural History, and advanced this one to a state of comparative arrangement. From this man of universal observation was derived almost all the information - the groundwork, at least, of all the works on Ichthyology till the seventeenth century; and even since this period he has been much relied on. Rondoletius and Salvianus gave figures of many species, those of the latter often very correct, and, at the same time, exhibiting curious specimens of engraving. But Willoughby and Ray were perhaps the first to attempt a methodical arrangement, founded upon structure; and it was onl: after their time that the science and its promoters became more generally known. Artedi, a name dear to every ichthyologist, with Linnæus, and his numerous pupils, pursued it in its systems; Pennant and Pallas studied it with enthusiasm, and were assisted in their knowledge of species 
by the results of the scientific voyages of Commerson, Sonnerat, \&c., and in their physiological researches, by the works of Haller, Camper, Monro, and John Hunter.

Following these great names, we had, for the arrangement and descriptive parts, the Ichthyologies of Lacépède, Russell, Shaw, Dumeril, Risso, Rafinesque, Donovan, Jurine, Hamilton Buchanan, and the outline of Cuvier in the Regne Animal: these men availed themselves of the numerous scientific voyages which Europe, at the termination of the last and commencement of the present century, has been so liberally supporting, and which have collected so much information in every branch of Natural History; while in the physiological details may be mentioned the names of Geoffroy St. Hilaire, Carus, Humboldt, and Sir Everard Home.

In this immense array of science, in which have been noted, as it were, only the very heads, a stupendous collection of facts have been recorded, which, however important, curious, or amusing, remained alone on the authority of their discoverers, memorials of their persevering research; but they. were neither arranged nor collected, and the want of some general system for this science, by which a definitive state of our knowledge could be gained, was indispen- 
sable for its progress, and eagerly called for by every naturalist in Europe. The long experience of the Baron Cuvier was destined to commence the filling up of this gap; and the foundation of the structure has been laid, and so far raised, in a manner worthy of its builder, in the work we have selected as our "Text Book" for the present volumes. In 1828, Cuvier commenced the arrangement of the materials which he had been collecting during his whole life, for a "Histoire Naturelle des Poissons," and with the assistance of a younger, but able naturalist, has published nine volumes, illustrating the greater part of the first section of the divisions into which these creatures have been separated by him. We now propose, after giving a short sketch of the nature and uses of Fishes, to proceed to the detail of those contained in the first section of Cuvier's arrangement [See Table of Cuvier's arrangement, p. 86], so far as the limits of this volume will allow, and at the same time making use of the information which several interesting voyages have given, since the publication of the first parts of the Baron's work.

But before proceeding with this part of the subject, we must very shortly notice another branch, which, till lately, has been comparatively 
neglected-that of Fossil Ichthyology. Previous to 1600 , there are perhaps few records of fossil fishes. Fabius Columna and Worm wrote De Glossopetris; in the following century, we had Scheuchzer and Fischer; and, towards its conclusion, the Ittiolitologia Veronese of Volta, a large folio containing seventy-six plates, which, if not very faithful in execution, showed the interest which was at this time excited; but it was not until so late as 1818 , that an enumeration of the fossil species, previously known, was first attempted by De Blainville in Le Nouveau Dictionnaire d'Histoire Naturelle. Since then, the science has gradually advanced, from its intense interest, and its connection with the studies of the geologist; and at the commencement of the last year, it assumed a most important station from the researches of a naturalist of Switzerland, and the appearance of the first numbers of a work devoted to this department. The Recherches sur les Poissons Fossiles of Louis Agassiz will undoubtedly mark the commencement of a new era in this science; for, independent of the perspicuity and clearness with which the department itself is illustrated, the study of existing species being necessary for a knowledge of those which are extinct, has induced the author to give his views of the science 
generally, and to propose an arrangement entirely different from those of his predecessors, the characters of which are principally taken fom the form and structure of the scales. His orders are as follows :-

I. Placoidians - So named from the irregularity presented by the solid parts of their covering, composed of masses of enamel. It includes many fossil forms, the Sharks, and Rays.

II. Ganoidians - Containing varied forms, the Sauroid fishes, Siluri, Sturgeons, \&c., characterized by scales of an angular form, composed of two substances, plates of horn or bone, placed one upon another, and covered by a thick layer of enamel.

III. Ctenoidians - The common character is in the thin plates forming the scales, being pecti nated or toothed on their posterior edge, which makes them feel rough to the touch. It contains the Chetodons, Pleuronectes, the Percoid fishes, \&c.

VI. Cycloidians-They have the scales formed of simple plates, those of the lateral line with a tube for the transmission of the lubricating mucus. It includes the Mullets, Salmon, Cyprini, \&c.*

* If we estimate the number of fish now known, to amount to about 8000 , we may state that more than three- 
The situation in our systems which has been allotted to fishes, has generally been the fourth place, or the lowest rank, in the seale of the vertebrata. They seem to have been more particularly connected with the class which immediately precedes them, by those most extraordinary creatures, long since extinct, but which now oceupy so much of the attention of the geologist, the Ichthyosauri or Fish-Lizards, and which the discovery of new forms lead us to believe were a numerous race, perhaps possessing intermediate ability to exist either in air or water. Fishes are entirely inhabitants of the waters, peopling this immense portion of our globe with their shoals, and serving to keep in check the varied creatures of still lower structure, while they themselves are held in check, and afford sustenance to millions

fourths of this number belong to two only of the above mentioned orders, the Cycloidians and Ctenoidians, whose presence has not been discovered in formations below the chalk.

The other fourth part of living species is referable to the orders Placoidians and Ganoidians, which are now far from numerous, but which existed during the whole period which elapsed since the earth began to be inhabited, to the time when the animals of the Greensand lived.

M. Agassiz does not know a single species of fossil fish which is found successively in two formations, while he is acquainted with a good number which have a very considerable horizontal extent.-Ed. Phil. Jour. xxxv. 175. 
which have been placed in our systems above them. In form they are perhaps the most varied beings in creation, and the most fertile fancy could scarcely depict a shape or appearance to which a resemblance would not be found. They are of "hideous and loathsome bulk," or of the most graceful forms, and gorgeous and resplendent colours; but still among all these we may trace the characteristic shape of a fish, in the head being placed at once upon the shoulders without any length of neck, followed by the body, and finished by the tail; and the parts will be all adapted to the different modes of gaining sustenance, whether it is to be procured by stealth and deceit, or by strength and swiftness.

Living in a different element from that which maintains most of the mammalia and birds, we find the external covering of fishes to consist of plates, or scales, supplying the place of hair or feathers. The skin of fishes completely surrounds the body, clasping close to the muscles, and serving as an outward skeleton, as the bones do for a protection to the inward parts. The scales are composed of two substances, the one allied to that of horn, the other to that which forms the enamel of teeth. They are placed in little mucous cavities of the corion, or true skin; they are generally formea of delicate plates or leaves, secreted by the skin, 
and placed above each other in successive layers, each of which can be separated by maceration in water. When the enamel is present, it generally

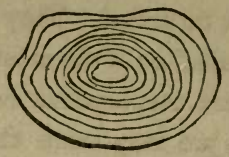

forms a thick layer above these. They are often transparent, and transmit the bright colours and metallic tints which are secreted beneath them, while the different manner in which the layers are deposited, give rise to many of the figures we see, as it were imprinted, on their surface. A few species have the skin nearly smooth, and apparently defenceless, and without scales or plates.

The scales are held in position by a fold of the epidermis, often so delicate as scarcely to be visible, but which covers almost the whole part of the fish exposed to our view. They fold over each other in different modes of imbrication, sometimes regularly like the tiling of a house, sometimes in a lateral form, or with the lower longitudinal edge folding over the upper edge of the scale below; sometimes alternately, so that the joining of the preceding scale is opposite the centre of that which follows, while in others 


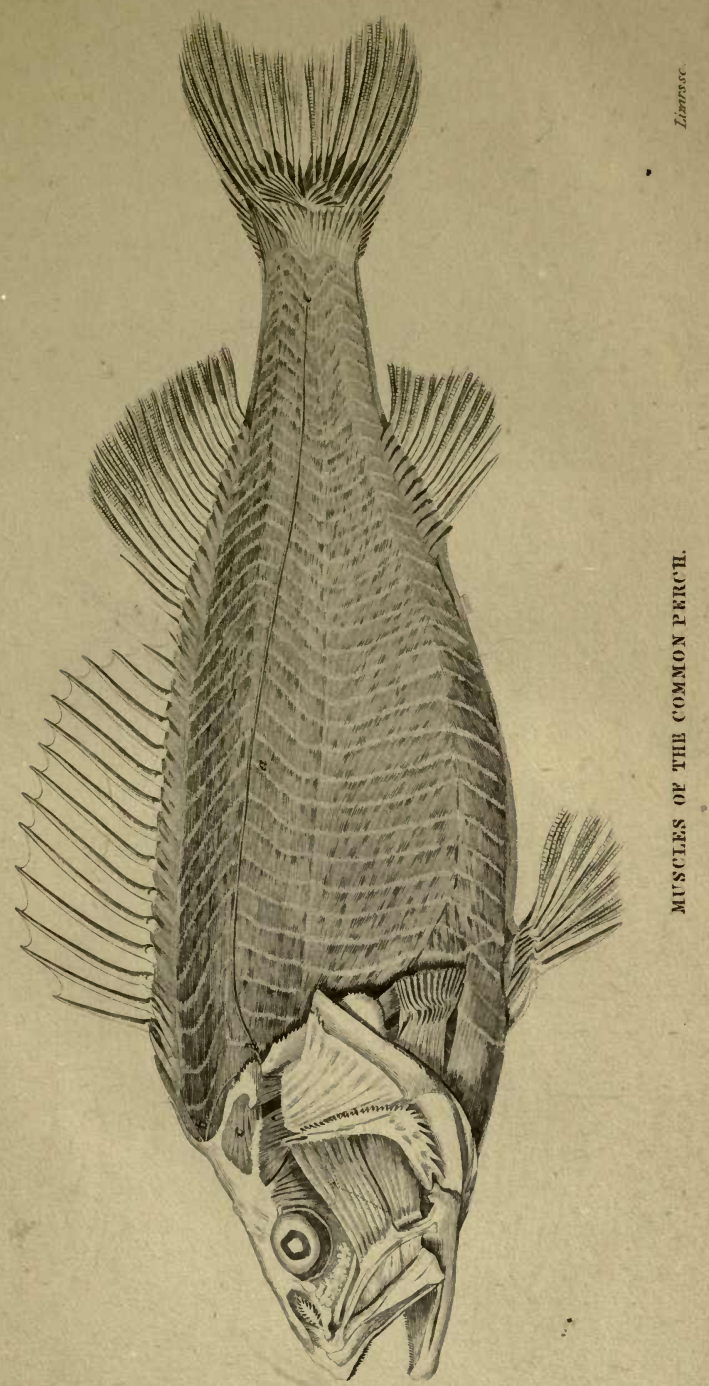


REESE LIBRAPY
OF THE
UNIVE RTTY
CALIFORNIA. 
there is no imbrication at all, and the edges meet like plates or the flags of a pavement. But one of the more remarkable contrivances for holding them in connection, is seen in some fossil species, where the incumbent scale is furnished with a hook, or tooth, which fits into a corresponding hollow in the lower edge of the upper scale, better understood by inspecting the accom?anying cuts of those of (1) Paleoniscus* Freieslebeni, and (2) Pholidophorus $\uparrow$ macrocephalus, Agass.

1.

2.
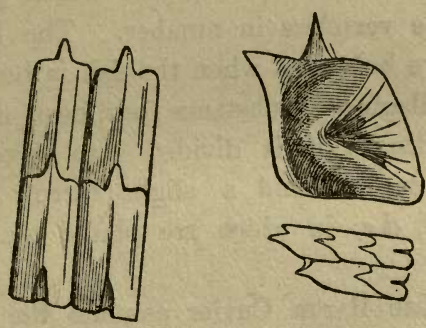

The skin is immediately attached to the muscles, the outer lateral layer of which will be seen in the accompanying plate, (PI. XXXI.) One great muscle (a) occupies nearly the whole side, and is almost the only one which is externally

- sarasos, ancient ; ovioxos, oniscus.

† podsoopsgos, scale-bearing, like a snake. 
visible. It arises from the upper part of the head, at $b c$, and the bones of the shoulders, and is inserted into the sides of the bone of the tail. It is separated above from its corresponding muscle on the opposite side, by the spine and its epiphysis, by the deep muscles of the interspinal bones, and by the ribs which surround the abdominal cavity; beneath it widens to admit the lower fins and the muscles which belong to them. The structure of this great muscle is complicated. It is transversely composed of slips held together by a tendinous expanse, and which generally equal the vertebræ in number. The layers or plates are best seen when the fish is boiled, and the cartilaginous substance has been dissolved. Longitudinally it is divided into three bands. In the centre band a slight furrow may be observel, $d e$, in which are placed the mucous glands.

The late Baron Cuvier assumes the common perch, among fishes, as the form in which the greatest general perfection is exhibited (see Common Perch, Plate XXXV.); and being a species familiarly known to almost every one, will serve better than any other to convey an idea of this class of beings; and the accompanying Plate (XXXII. of the Skeleton of the Common Perch), exhibits the bony structure in osseous 


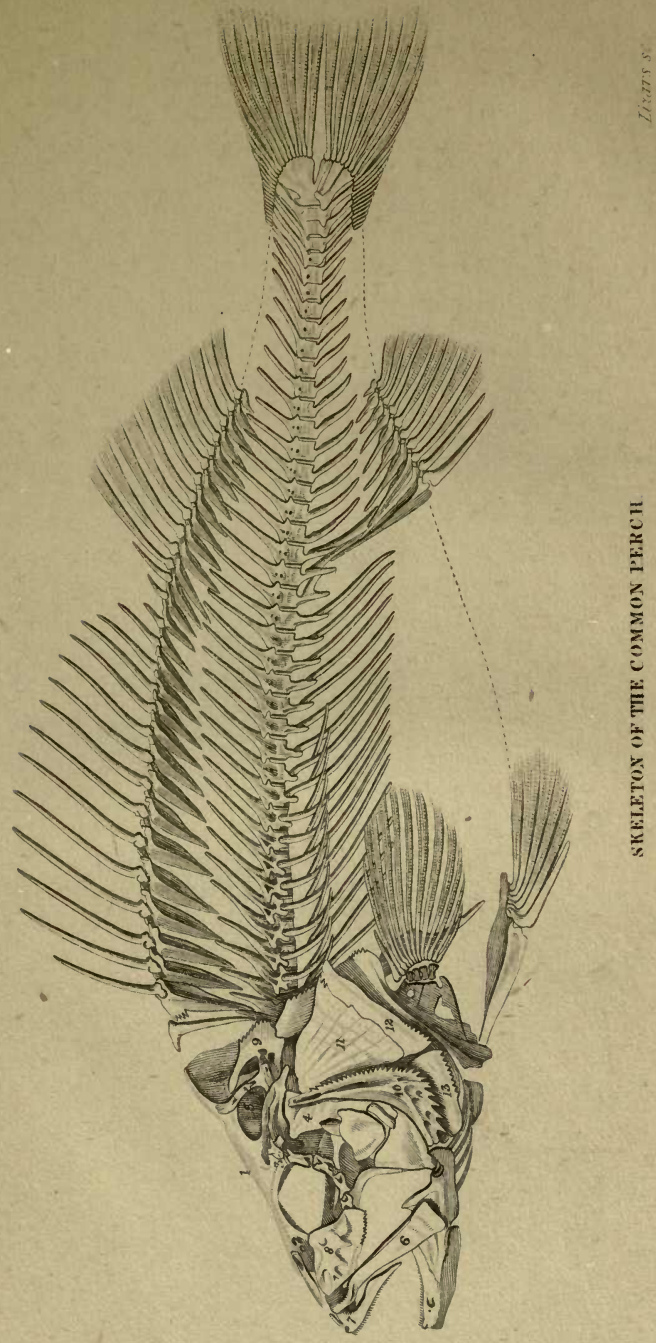




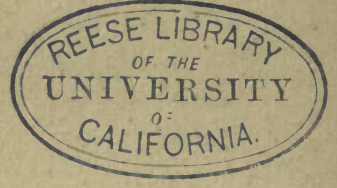


fishes. No. 1 is the principal frontal bone; 2 . Anterior frontal bone; 3. Posterior frontal bone; 4. Temporal bone; 5. Parietal bone; 6. Maxillary bone; 7. Intermaxillary bone; 8. Suborbitary bone; 9. Supra scapular bone; 10. Preopercle; 11. Opercle; 12. Subopercle; 13. Interopercle. The above references will enable the observer to understand the characters of the genera, which are, in a great measure, taken from the form of these bones in the head.

In the perch, and indeed in all those fishes which are endowed with extensive locomotive powers, or require swiftness to seize their prey, the tail is the great organ of motion, while the fins are the balancers or directors, a contrary arrangement to that shewn in the members of those creatures of the land and air, where the tail is the director or lielm, the feet and wings the movers. The fins on the upper surface serve to balance the body, those on the lower surface to turn it, to move it slowly, and to keep it suspended in strong currents; but in all these, the motion or assistance of the tail is observable. In very swift motion the fins are quiet; the creature could not keep them extended, far less use them, and they fold closely to the body, and offer no resistance to its rapid passage through the water. In what are called flat fish, however, and in all those whose horizontal 
surface is large, the fins assist considerably in progressive motion, and their motion upwards and downwards, and not in the line of progression, offers no resistance.

Another powerful accessary in the buoyancy of fishes, is what is called the air, or swimming, bladder; and whatever functions it may hereafter be found to possess, similar or resembling those of the lungs of aërial beings, there can be no doubt of its assistance when a fish wishes to rise or sink. It is generally situated in the upper part of the ventral cavity, running parallel to the spine, and it often communicates with the intestinal canal, by an opening placed near the boundary between the csophagus and the stomach, though in some fishes no communication or opening has been discovered. In those where no communication with the œsophagus has been found, it is conjectured that the air in this organ is secreted within it; and this opinion has been strengthened by the presence of a red fleshy body occurring on the interior of the walls of the bladder, and by the influence which a wound in the bladder produced in the function of the gills upon the blood. It is a very curious subject, difficult to investigate, and several eminent ichthyologists have adopted the opinion of this organ in part performing the office of 
lungs. It is of various shapes, sometimes seeming like a simple bag extending the whole length of the cavity, sometimes cut as it were in two, by a narrow stricture, and having the appearance of two irregular sacks. The supply of air can be compressed by muscular action, and accordingly will serve to assist in raising or sinking the animal; and it is remarkable, that in those fishes which reside much at the bottom, and seldom or never come to the surface, this organ is almost always wanting.

But independent of the common manner of progressive motion among fishes, other means have been given them, by which either a great accession of power is added; or where the ordinary limbs are small, or wanting, organs of an entirely different nature have been constructed. In a genus of fishes, mentioned by almost all travellers as amusing the weariness of a long sea voyage, the immense development of the pectoral fins, and the power the animal possesses of raising and sustaining itself for a considerable time above the waves, has gained for it the epithet of Flying. The action, however, appears to have more resemblance to a long and vigorous leap, than to flight as practised by the denizens of the air. A difference of opinion exists as to the motion of the pectoral fins, whereby they are for the time 
supported. Cuvier says the animal beats the air during the leap, but we question if this is said from actual evidence. Dr Abel, however, supports the assertion in his voyage to China; but $\mathrm{Mr}$ Bennet, a later observer, is of a contrary opinion. " The flight of these fish," he remarks, " has been compared to that of birds, so as to deceive the ; observer ; however, I cannot perceive any comparison, one being an elegant, fearless, and independent motion, whilst that of the fish is hurried, stiff, and awkward, more like a creature requiring support for a short period; and then its repeated flights are merely another term for leaps. The fish make a rustling noise, very audible when they are near the ship, dart forward, or sometimes take a curve to bring themselves before the wind, and, when fatigued, fall suddenly into the water. It is not uncommon to see them, when pursued, drop exhausted, rise again almost instantly, proceed a little farther, again dipping into the ocean, so continuing for some distance until they are out of sight." * With this view we are rather inclined to coincide; but however the motion is performed, it is certain that they can progress out of the water, according to Captain Hall, for a distance of at least two hundred yards, and

* Bennet's Wand. i. p. 33. 
according to $\mathrm{Mr}$ Bennet, to a height of from two to twenty feet.

Another manner of transportation is by means of an apparatus by which the animal can fix itself to any object in motion. Many fishes are supplied with an organ of this kind, which also seems to be used as a means of keeping themselves secure amidst the turmoil of a storm, affixing themselves to rocks and other steady substances Among the most remarkable of these is the $R e$ mora, or Sucking Fish, far famed in ancient story for its power over the vessels of the mariner. These fishes are of a narrow lengthened form, the head large in proportion to the body, and furnished with a flat oval shield composed of transverse plates, each furnished with a row of fine teeth: this is termed the sucking plate, and by means of it they attach themselves firmly to the bodies of larger fish, or the bottoms of ships, and are thus transported. The common White Shark seems to be their most frequent carrier, to which four or five have been often found attached. The tail and fins of the Remora are all comparatively very small, and the fish has no air bladder.

The Perca scandens transports itself, and scales rocks, and even plants that grow from the water, by means of the alternate use of the spines of the pectoral fins, and M. Renau has asserted that he 
knew a species of Lophius which walked about the house like a dog; while the Doras costatus, by the bony arms of its fins, assisted by the plates under the belly, which work like those of serpents, can march over land as fast as a man can leisurely walk.*

The body of fishes is Jubricated by a slimy fluid, prepared in a series of glands generally placed near and about the fore parts, a beautiful natural arrangement, to allow the fluid to be carried backward; or the same office is performed in a more mechanical manner by what is called the lateral line, and which is in reality a canal on the scales, which is either continuous, and conveys the lubricating fluid backwards from the head and neck, or has a communication with a series of glands laterally disposed.

In the Skate there is a large serpentine vessel which surrounds the mouth, runs between the skin and the muscles at the sides of the five apertures into the gills, and likewise surrounds the nostrils; then it passes from the under to the upper part of the upper jaw, where it runs backwards as far as the eyes. From the principal part of this duct, in the under side or belly of the fish, there are not above six or eight outlets; but from the upper

- Dr Hancock, Zool. Jour. 
part near the eyes there are above thirty small ducts sent off, which open on the surface of the skin. But besides this very picturesque duct, there is on each side of the fish, a little farther forwards than the foremost of the five breathing holes, a central part from which a prodigious number of ducts issue, to terminate on almost the whole surface of the skin, excepting only the snout or upper jaw. At these centres the ducts are all shut, and in their course have no communication with each other.* In the skate the whole cellular substance of the nose or snout secretes a mucus, which is dispersed by bundles of tubes opening exteriorly. The Eel and Conger have large openings at different parts of the nose, communieating with numerous lengthened vessels analogous to the winding canals of the Skate. $f$ But in almost every fish these have a distribution differently managed according to their wants, forming one of the most beautiful and necessary provisions in their whole structure. That of the Cod, from its simplicity, will best shew it, reduced from one of the characteristic plates of Monro.

- Monro, pl. vi. vii. + Cuvier, i. 252. 
a The termination of a large lymphatic, which begins at the tail and runs upwards on the side of the fish, receiving its branches from the skin and muscles of the trunk at nearly right angles.

$b$ The upper end of a mucous duct, which runs upon the side of the fish nearly parallel with the lymphatic $a$, and which has numerous short branches, with open mouths, which pour out mucus upon the surface of the skin.

$c$ is the continuation of the duct $b$ cut open.

$d$ Another mucous duct, having no communication with $b$ or $c$, and which discharges its mucus upon the surface of the skin of the under jaw by a number of short branches.

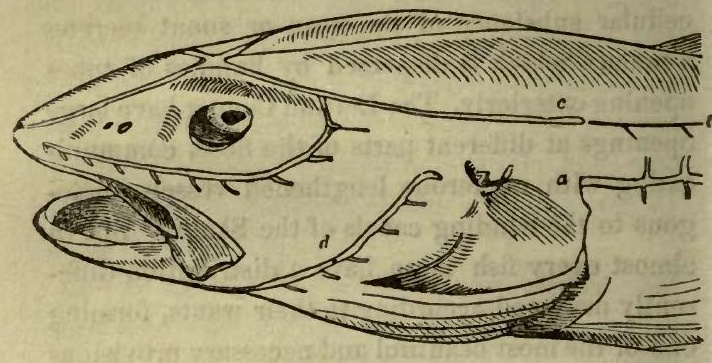

One of the most remarkable contrivances in the economy of fishes, is their respiration. The medium which contains the air, being fatal to all terrestrial animals which would attempt to inhale them in conjunction, a different apparatus for their employment was necessary, which we find in the form of branchice or gills, as they are termed, placed near the forward extremity 
of the animal, and protected by a bony case or covering, often defended by strong spines, which in the horrid array which covers some species, are almost always placed on these parts. This sort of respiration has been termed aquatic, and, among the vertebrata, is found in the larva or young state of some reptiles which spend the early portion of their existence in the waters, and in all the fishes. The gills are placed in immediate communication with the heart, and are composed of an innumerable series of delicate bloodvessels arranged in a fringe-like form upon the lower edges of four bony arches, which form the frame work of this structure. Water entering at the mouth, is forced out again at the posterior opening of the covers, and thus maintains almost a constant stream or rush through them, entering and again expelled, at intervals, similar to the respiration and expiration of animals. When withdrawn from the water, the delicate filamentous structure of the gills immediately collapses, and no muscular exertion, or convulsive action, can restore them to their former play; when exposed to the action of air only, a kind of suffocation ensues, and death is the consequence. This is the general principle of respiration in this class of beings, but the structure and its application is often modified. The admission and exit of the water is sometimes 
performed independently of the mouth; and those species which can exist for longer periods than usual out of their native element, have the power of retaining a portion of water in a membranous sack or bag surrounding the gills, which keeps the filamentous structure moist, and enables the animal to continue the respiratory action. Such is the case with a very singular fish, the Doras costatus, a native of Demerara, which possesses the singular property of deserting the water, and travelling overland. In those terrestrial excursions, large droves are frequently met with during very dry seasons, for it is only at this season that they are compelled to this dangerous march, which exposes them as a prey to so many and such various enemies. When the water is leaving the pools in which they commonly reside, they simultaneously quit the place, and march overland in search of water, travelling for a whole night in search of their object. "I have observed," adds Dr Hancock, "that their bodies do not get dry like those of other fishes when they are out of the water; and if the moisture be absorbed, or they are wiped dry with a cloth, they have such a power of secretion, that they become instantly moist again. Indeed, it is scarcely possible to dry the surface while the fish is living." *

* Dr Hancock, Zool. Journ. No. XIV. p. 242 
The senses among fishes may almost be said to be confined to three,-those of seeing, hearing, and smelling, all very acute. Those of taste and touch are to all appearance in subordinate development, nor with the powerful exercise of the others are they conducive, or necessary to the existence of the individual. There is a general sense of feeling by contact with any body over the surface of the animal; but unless in those species which are furnished with long filamentous appendages to the head, there is no organ by which this property is regularly exercised. In those fish, when lying at the bottom in disturbed water, the filaments are extended, and may serve to make them aware of the approach of an enemy; and among others, in the Siluri, where they are of great length, and are thrown out and moved, to attract attention; from their sensibility of touch, while the fish remains in concealment, they may warn the lurker that his prey approaches, and enable him to prepare for its seizure.

The sense of taste seems even developed in a less degree, the organ in which it is generally implanted being used as an accessary to prehension, and often armed with very strong teeth. Swallowing also almost immediately follows the seizure; the prey, gorged entire, and without mastication in the mouth, is rapidly dissolved and digested in the stomach. 
The important function of vision is imparted to fishes to a greater extent, and if perhaps the range of seeing be not great, when within its bounds it is apparently acute and distinct ; and as among the higher vertebrata we have some which are nocturnal in their habits, as well as those which seek their prey by day, so we find among fishes a difference of form in the large eyes of many species which constantly remain at a depth of many hundred fathoms below the surface, and where it has been proved that the influence of light could not extend. In some, again, the eyes are remarkable for their minuteness, and to several species the specific name Caca, or blind, has been applied. These, like the mole in her dark galleries, live in the banks of muddy rivers, and are no doubt furnished with some more exquisite sense to supply their wants, and minister to their sustenance. In the Gastrobranchus, a fish remarkable in all its structure, no trace whatever of eyes has yet been discovered.

Water, the medium through which fishes hear, has been proved to be a better conductor of sound than air ; and from a variety of experiments, sounds produced under water, have a loud and clear impression on the human ear, placed in the same situation. In fishes there is no external ear, except in a few where a very small cavity is discernible. They want the tympanum, the small bones, and the enstachian tuibes; but the semi- 
circular canals are often largely developed. In the osseous fishes, to a part of which this volume is more particularly devoted, the whole of the labyrinth of the ear projects into the cavity of the cranium. The labyrinth is filled with a transparent liquid, distending the vestibule and sack, which contain small and peculiar bony substances, two or three in number, which float in the liquid, and would apparently convey the sense of any concussion to the nervous linings of the edges, and upon the principal plexus of the auditory nerve, which is ramified in the greatest proportion on the walls of the sack, which generally contains the largest of these hard osseous bodies. The structure of the ears in fishes is certainly less perfect and less complicated than in the higher mammalia and birds; and Cuvier is of opinion, that though they hear sounds distinctly, or as concussions, yet they are unable to distinguish any of the finer tones or variations. That they are sensible of the impulses of sound has often been proved, and fish are known to approach for sood at the whistle of their keeper.*

Smelling, again, appears to be even farther developed than what is generally supposed. The

* The Romans were even said to have taught each to approach upon calling by a particular name. Frecynet, speaking of the Squalus melanopterus which the expedition met with at the Waigow Islands, says they 
nostrils, in general, appear externally like a double hole or opening, and the branches of the nerve are ramified on a sort of cushion at the bottom, or upon the side. The cut will shew

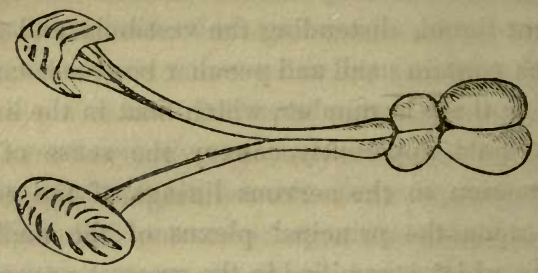

the great proportion of nerve supplied from the brain to the nostrils. In a few, they are like prolonged tubes, as among the eels, where the multiplicity of nervous filaments is very great; and in one fish they are remarkable as being placed on a sort of stalk like a mushroom, in which the openings are placed with the nervous distribution. Seeing, then, a certain extent of development, we cannot doubt that impressions of smell are conveyed. In proof, various perfumes are successfully used by anglers to attract the fishes. Eels are led into traps by baits placed within, which they could only discover by smell;

appear to have a finer sense of hearing than of sight. When seen upon the coast, they would allow themselves to be approached, so long as silence was preserved, but on speaking, fled immediately. 
and during floods, or in muddy waters, where we know that vision is much impaired, scent only can bring fish to the bait, which, if employed for a continuance in one spot, will at length attract numbers. But Cuvier hints at this sense being even of service for a purpose of more delicacy - that of distinguishing the difference between waters of different streams or currents ; and it is probable, that, by the use of these organs, many of our migratory fresh water species are enabled again to discover and return to the rivers they had previously frequented. Such seems the most common distribution of the three most prevalent senses. Various, however, are the modifications of their application, corresponding with the manners and necessities of the individuals.

The greater proportion of fishes are carnivorous, and find an abundant and varied food in the immense profusion of moluscous animals, as well as in the smaller species of their own orders, for among them may be said to exist a constant system of attack and defence - a general war, the stronger against the weaker. A few only subsist on vegetables, "and graze the sea weed, their pasture." The teeth, the only organs almost of prehension, are therefore varied in innumerable forms, but are chiefly adapted either for tearing or bruising. In the cartilaginous fish, we find these forms strongly developed; those of the 
sharks will exhibit an example of the first, of the most formidable kind, of great size and strength, smooth and piercing, or sharp, but serrated. Those of the rays or skates of the second, fitted for bruising, where the food is in a great part shell fish, and where the teeth are arranged as a dense pavement. In others, again, the teeth, various in size and strength, are placed in the jaws, vomer, tongue, arches of the branchiæ, and in the throat. The latter arrangement is one of the most singular, and bears the title among French ichthyologists of "Dents en velour," from their exhibiting the appearance, to the naked eye, of the pile of coarse velvet. These act by the compression of the lower pharyngeal muscles, and an example will be found in the genus Cyprinus, to which belong the greater part of those fishes which, by English anglers, are denominated "Leather Mouths." The food being seized, is almost immediately swallowed; and, such is its voracity, that substances entirely foreign are often taken in, as may almost always be seen on examining the stomach of a cod, which sometimes presents a most heterogeneous mass, little fitted for nutrition.

Although the teeth and jaws, with pursuit, are the principal accessaries for securing prey, various fishes, deprived of swiftness, entice their prey by stratagem. Such are all the Siluri, with long filainentous appendages to the lips, which, in some, are 
saia to possess the property of stinging. Others, again, lurk in concealment, and dart out upon the casual passers by. The Rostrated Chætodon employs a most singular property of propelling a drop of water with unerring aim and considerable force at insects which have settled on aquatic plants, seizing them on their fall into the water. But of all the properties with which these singular creatures are endowed, either for attack or defence, that of the benumbing and electric stroke of the Torpedo and Gymnotus is the most remarkable. Experiments have tendea to confirm its connection with the galvanic innuence. Many an assailant must be most unexpectedly stopped by it; and the fishes whicn are endowed with it being, in general, of slow motion, lurk until their victims approach within the influence of their deadly and peculiar power.

The fishes which possess this power are but few in number. Among the most noted are the Torpedo known to the ancients, and the electric Gymnotus. In the first, which in outward appearance somewhat resembles a skate, and has nearly the same habits, the electric organs are placed on each side of the cranium and gills, reaching from thence to the semicircular cartilages of each great fin, and extending longitudinally from the anterior extremity of the 
animal to the transverse cartilage which divides the thorax from the abdomen, and within these limits they occupy the whole space between the skin of the upper and under surface. Each organ consists wholly of perpendicular columns, reaching from the upper to the under surface, and varying in their lengths according to the thickness of the parts of the body where they are placed. Their coats are very thin and transparent, closely connected with each other by a kind of loose network of tendinous fibres. The number of columns vary in specimens according to size. John Hunter found about four hundred and seventy in each organ; but in one of large size, so many as one thousand one hundred and eighty-two were counted; and the whole are supplied with a very ample plexus of nerves.*

The Torpedo being the fish first known which possessed this property, had the fame of the immense benumbing power which it could exert spread abroad. Experiments have proved, however, that the shocks could be withstood with impunity, and that some other fishes possessed it to a much greater extent. It can be communicated through the water without contact; and is undoubtedly used in striking the prey which it

- J. Hunter's Phil. Trans. 
is unable to overtake from its unwieldiness. Leoman mentions, that a duck, confined to a bucket of water containing a live torpedo, was, after some hours, found dead. Several species are known; four are found in the Mediterranean.

The electric Gymnotus, recorded by Humboldt, is a much more formidable creature, as we learn from the interesting account of that traveller. He found them in the Rio Colorado, and several other streams which cross the missions of the Chayma Indians. The natives frequently feel the electrical shocks when bathing in the waters, and every amphibious animal seems to have an intuitive fear in approaching the pools which they inhabit; the alligator is stunned before he can wound them; and it was even necessary to change the direction of a road near Urituca, because these electrical eels were so numerous in one river that they every year killed a great number of mules of burden as they forded the water. The manner in which the Baron procured specimens for examination is a curious instance of their power. It was necessary to procure them without injury; and, after resorting to different expedients, " the Indians told us they would fish with horses. We found it difficult to form an idea of this extraordinary manner of fishing; but we soon saw our guides return from the Savannah, which they had been scouring for wild horses and mules. They 
brought about thirty with them, which they forced to enter the pool.

"The extraordinary noise caused by the horses' hoofs makes the fish issue from the sand, and incites them to combat. These yellowish and livid eels, resembling large aquatic serpents, swim on the surface of the water, and crowd under the bellies of the horses and mules. A contest between animals of so different organization furnishes a very striking spectacle. The Indians, provided with harpoons, and long slender reeds, surround the pool closely, and some climb upon the trees, the branches of which extend horizontally over the surface of the water. By their wild cries, and length of their reeds, they prevent the horses from running away, and reaching the bank of the pool. The eels, stunned by the noise, defend themselves by repeated discharges of their electric batteries. During a long time they seem to prove victorious. Several horses sink beneath the violence of their invisible strokes, which they receive on all sides, in organs the most essential to life ; and, stunned by the force and frequency of the blows, disappear under water. Others, panting, with mane erect, and haggard eyes, expressing anguish, rouse themselves, and endeavour to flee from the storm by which they are overtaken. They are driven back by the Indians into the middle of the water; but a small number 
succeed in eluding the active vigilance of the fishermen. These regain the shore, stumbling at every step, and stretch themselves on the sand, exhausted with fatigue, and their limbs benumbed by the electric strokes of the Gymnotı.

"In less than five minutes two horses were drowned. The eel being five feet long, and pressing itself against the belly of the horses, makes a discharge along the whole extent of its electric organ. It attacks at once the heart, the intestines, and the plexus of abdominal nerves. We had little doubt the fishing would terminate by killing successively all the animals engaged; but, by degrees, the impetuosity of this unequal contest diminished, and the wearied Gymnoti dispersed. They require a long rest, and abundant nourishment, to repair what they have lost of galvanic forces and, in a few minutes, we had five large eels, the greater part of which were only slightly wounded."*

The reproduction and migration of fish is another part of their history full of interest. They are, with a few exceptions, oviparous, and are fruitful to a most surprising degree - so much so, that if the whole ova were to be matured, bounds could not be assigned to them, and the expanse of the waters would be crammed; but among

* Humboldt's Pers. Narr iv. 349. 
the millions of ova which are deposited, those hatched to maturity will not exceed one in the thousand, perhaps a much less proportion, and in their great fertility we see both a beneficent design in furnishing an ample supply of food for many of the inhabitants of the same element, and for the numerous tribes of waterfowl which, at some seasons, feed entirely on the eggs and fry; while, on the other nand, without this abundant power of generation, a stock could not be saved from the numerous enemies of sea and air to which they are nearly constantly exposed. In general, the eggs are deposited in water comparatively shallow, upon rocks, on gravelly or sandy banks, on aquatic plants, or marine algæ, or in holes formed in the banks or borders of the lakes or rivers; and to the strong instinctive principle which impells these creatures to seek suitable situations for the deposition of their spawn, do we owe the abundant supply of fish which annually resort to our shores. The migration of the herring, mackerel, pilchard, \&c. all depend on this, and the countless shoals which arrive, only leave the great recesses of the deep to seek the shallower bays and estuaries for the purpose of continuing their species.

There is one circumstance in the breeding of fishes which requires notice - that of no care being bestowed on the ova, or young, after a 
place has been selected and finished for the deposition, or after they are hatched. There seems, however, here also to be exceptions. "The Caltichthys littoralis makes a regular nest of long leaves, or grass, in which they lay their eggs in a flattened cluster, and cover them over most carefully. They remain by the side of the nest till the spawn is hatched, with as much solicitude as a hen guards her eggs, both male and female, for they are monogamous, steadily watehing the spawn, and courageously attacking any assailant. Hence the negroes frequently take them by putting their hands into the water, close to the nest, on agitating which, the male springs furiously at them, and is thus captured." *

In their economical uses to man, fish are principally important as an article of food, and from the employment they afford to the more dependent classes; but oil is the commodity greatest in value and quantity produced from them., The quantity of fish killed for these purposes is truly immense. Fifty thousand salmon are said to have been taken in the Tay during one year, and five hundred thousand cod, on the Newfoundland bank, by a single vessel, in a week. What then will be the aggregate of the creatures in this department of zoology which are yearly

- Dr Hancock, Zool. Journ. XIV. p. 244. 
consumed in our commerce? Isinglass is made from the swimming bladders; glue from the coarser refuse of fins, \&c. ; artificial pearls from the scales, -and Pennant tells us that a certain French artist used thirty hampers full of the latter for this manufacture in one year. Shagreen from the skins of the cartiaginous fishes, sauces from their roe, \&c. may be mentioned as some of the more subordinate purposes to which they are applied.

In the arrangement of the present volume, we have preferred following the system of Cuvier. Its two leading divisions depend on the composition of the skeleton, with, however, some changes from any former arrangement. The next subordinate separation depends on the structure of the fin's rays; but the following short table will give an idea better than any exposition of our own.

\footnotetext{
POISSONS.

Osseux.

A branchies en peignes, ou in lames.

A machoìre superieure libre.
}

ACANTHROPTE RYGIENS.

Percöides.

Polynèmes.

Mrlles.

Joues cuirasseés.

Sciénoides.

Sparoïdes. 
INTRODUCTION.

Chetodonòides.

Scombröides.

Muges.

Branchies labyrinthiques

Lophiöides.

Gobioides.

Labroìdes.

\section{MALACOPTERYGIENS.}

Abdominaux.

Cyprinoides.

Siluroides.

Salmonoides.

Cluseöides.

Lucioides.

Subbrachiens.

Gadòides.

Pleuronectes.

Discoboles.

A podes.

Murenoides.

A mâchoire superieure fixée.

Selerodermes.

Gymnodontes.

A branchies en forme de houppes.

I.opobranches.

CARTILAGINEUX oU CHONDEROTERY GIENS.

Sturiones.

rlagiostomes.

Cyclostomes.

Pursuing farther the system of the Baron, wo shall commence our descriptive part with the characters of his first great family, the percoid 
fishes. Typical of this, the common perch has been taken, but, in considering its form, allowance must be made for the various modifications it will receive in the very numerous species which occupy this section; in the whole, however, the resemblance is beautifully kept up. The principal characters of the family are stated thus :- "The body oblong, more or less compressed, covered with scales generally hard, and of which the outer surface is more or less rough, the edges toothed or ciliated; an opercle and preopercle, variously armed or toothed; the mouth large; gill covers deeply cleft, the membrane supported by rays, whose number is never below five, and rarely exceeds seven; teeth not only in the jaws, but in a transverse line before the vomer, and almost always in a longitudinal band on each palatine bone; fins at least seven in number, often eight; stomach a sack, pylorus lateral, appendages never wanting, but often small and limited in number. The external colours are often beautiful; the flesh in general well flavoured and wholesome."

In the sectional divisions of the family, the leading distinctions are taken from the division of the dorsal fin, the situation of the ventral fins, and the form of the teeth, but for the sake of perspicuity, we add the table of the genera. 
1. - Ventral fins situated under the pectorals.

Ventrals with five soft rays.

Gills with seven rays.

With two dorsal fins, or with the first hollowed at its base.

Teeth all fine. (Dents en velour.)

1. Perca.

2. Lates.

3. Enoplossus.

: 4. Diplorion.

5. Labrax.

6. Centropomus.

7. Graministes.

8. Aspro.

9. Ambassis.

10. Apogon.

The canine teeth mingled with the others

1. Cheilodipterus.

2. Lucioperca.

3. Etelis.

With a single dorsal fin.

Canine teeth mingled with the others.

1. Serranus.

2. Merous.

3.

4. Plectronoma.

5. Diacope.

6. Mesoprion.

Teeth all fine. (Dents en verour.

1. Centropristes.

2. Grystes.

3. Polyprion.

4. Pentaceros.

5. Acerina.

6. Rypticus.

Less than seven rays to the gills.

Canine teeth mingled with others.

1. Cirrhites. 
Canıne teeth none.

1. Pomotes.

2. Centrarchus.

3. Trichodon.

4. Priacanthus.

5. Dules.

6. Therapon.

7. Pelates.

8. Helotes.

Ventral fins with more than five soft rays.

Gills with more than seven rays.

1. Myripristes.

2. Holocentrum.

3. Beryx.

II. - Ventral fins situated before the pectos als.

Teeth all fine. (Dents en velour.)

1. Uranoscopus.

2. Trachinus.

3. Percis.

4. Pinginpes.

Canine teeth mixed with others.

1. Percophis.

III. - Ventral fins situated behind the perioms.

With canine teeth.

1. Sphvræna.

Teeth fine. (Dents en velour.)

1. Polynemus. 


\section{GENUS PERCA - PERCH.}

The genus Perca, first and typical of the family, is familiarly known in the form of the Common Perch. The charzeters, after finding its place in the table, taken from the form and situation of the fins, may be shortly stated :- " Preopercle, toothed; opercle, spined; suborbitary bones, delicately toothed; tongue free. The dorsal fins are very powerful, the spines strong and sharp. The scaling moderately large, and with the posterior edge toothed. Swimming bladder very large. Number of vertebræ in the common species, forty-two." They are all inhabitants of the fresh waters, delighting in lakes and still running streams. Feed on marine insects and small fish. The colours are often brilliant, disposed in bands on the body, or distributed in vivid tints on the fins, which contrast with the more sombre shades. They inhabit Europe, India, North America, and a single species is mentioned, from the drawings of Banks, to be found in New Zealand. The sea-like lakes of America, and the sluggish parts of her vast rivers, afford the most numerous species; and to illustrate the genus we nave chosen one 


\section{THE GRANULATED PERCH.}

Perca granulata. - Cuv. et VAL.

\section{PLATE I.}

La Perch a Tete Grenue. - Perca granulata, Cuv. et Valen. Hist. Nat. des Poissons, ii. 48.
D. $15-2.13$; A. 2.8 ; C. 17 ; P. 15 ; V. 1.5 .*

The Granulated Perch inhabits the rivers which flow from the Blue Mountains towards the Atlantic Ocean, and, with two others from the same country, is so similar to that of Europe, as to have been confounded with it, and to have assisted in the idea that the latter was also found in the New World. It indeed approaches very closely by the bands on the sides, and the red colour of the lower fins; and the distinctions pointed out by Cuvier are the stronger teeth upon the vomer, the more delicate indentations of the preopercle, and the more irregular form of the cranium. The second dorsal fin has one ray more than that of the common perch, that of the first being 2.13 . the latter, 1.13.

* The rays of the fins will be stated, as above, at the commencement of each species, - the letters signifying Dorsal, Anal, Caudal, Pectoral, and Ventral. 


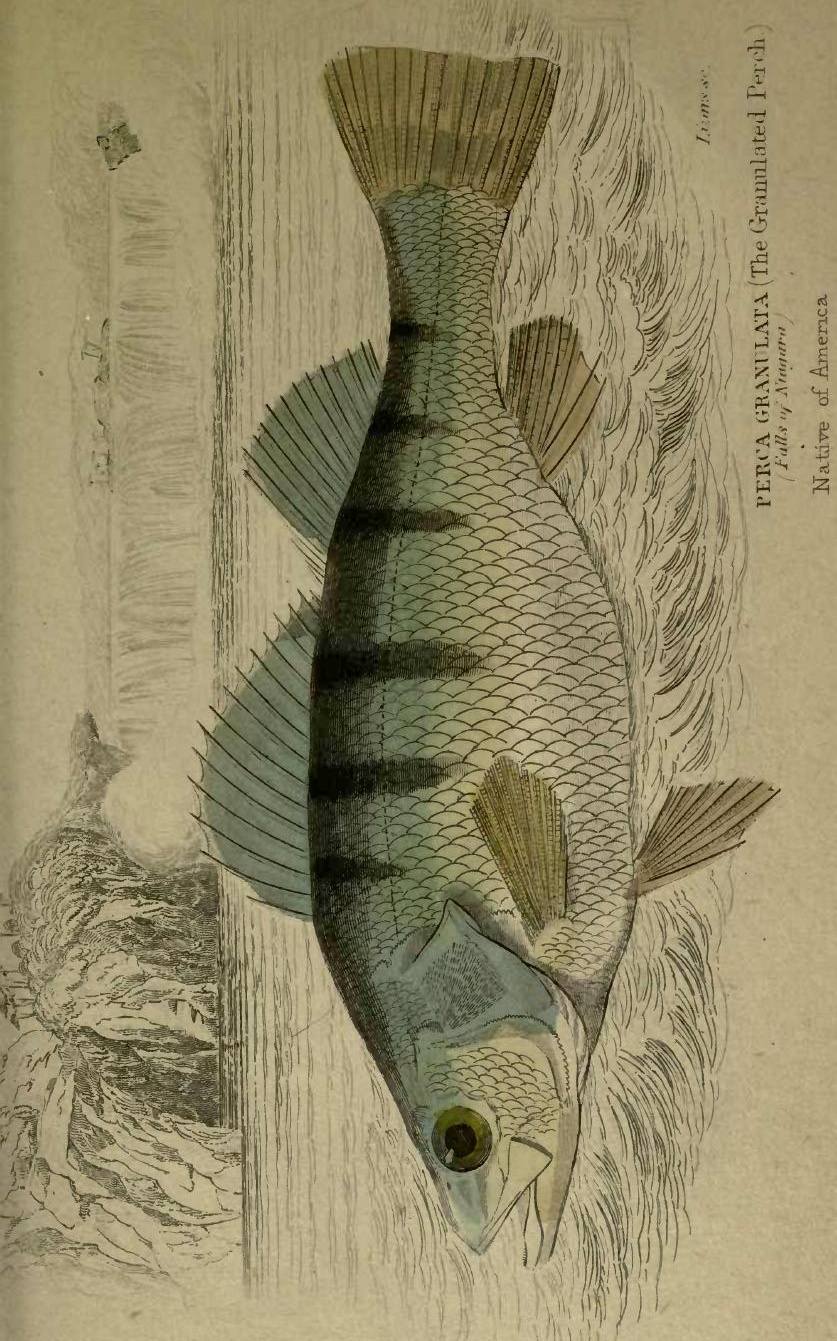




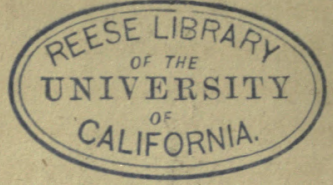


A species from Java is named $P$. ciliata, from the deeper cutting in or ciliation of the scales. Another, from Cook's Straits, differs from its congeners in being spotted on the sides, above and below the lateral line, with reddish golden coloured spots. The body of a lengthened form, silvery, the back with green and bluish bands nearly to the lateral line. It was found to be a fish of great delicacy of flavour; and, from its resemblance to a trout in spotting and taste, was named by Forster Sciena trutta.* Cuvier has now placed it at the extremity of his genus Perca.

The Common Perch (see Plate XXXV.), however, still continues the species which is most accurately known, and, among the fishes which are used in the economy of man, was the one which was perhaps most extensively and anciently used. It was known to the Greeks and Romans, and was celebrated for its beauty and delicacy, in the latter quality being thought worthy of contesting the palm with the far famed Mullet. In distribution, it is extensively spread over the lakes and rivers of Europe and a part of Asia; it extends to Italy, to European and Asiatic Russia, and is found in the rivers which flow into the Baltic and Black Sea. To Great Britain it is thought to have been introduced, and is now an abundant and well

* See detailed description, Schneider, 542, Addenda 
known fish in the southern lakes and rivers. It reaches to the north perhaps not farther than some lochs in Ross-shire, and to them it has most probably at some period been transported.

In the shape of the Perch, we find that combination of length, depth, and thickness, which will give the easiest support in, and the least resistance when passing through the water. While the fins possess great power, the swimming or air-bladder is of great size, and the scaling or outward covering is compact, hard, and not awkwardly large. In colouring it is extremely beautiful, the upper parts of a rich olive green, shading into golden yellow; the body banded with distinct bars of a deeper tint; and the whole relieved by the deep velvety black of the posterior part of the dorsal fin, and the brilliant vermilion of the ventral and anal fins. For defence, the strong spines of the aorsal fin, which are erected and held fixed with extraordinary muscular power upon the appearance of any danger, are admirably fitted, and it is one of the few fishes which is able to frequent waters in common with the Pike. A variety of the Perch is mentioned by M. Jurine, where all the colours are of a paler tint; the fins of a pale yellow, without any of their usual brilliant vermilion. Another, which Cuvier thinks may eventually resolve itself into a variety, is the fish which he has given under the title of Perca 
Italica - found in certain cantons of Italy, and, in particular seasons, seen in the Boulogne markets. It is without the dark side bands, but differs also slightly in some of the proportions of the head and fins. The Wales variety, mentioned by Pennant, consists in the hunched form of the back, and the distorted form of the back-bone next the tail, which appears first pirched in, and again expands.

As an article of food or luxury, we cannot agree with its celebrator, Ausonius, in its excellency over our other fresh water fishes. When of average size, it affords a fine variety for the table, but will be surpassed in delicacy by either the Trout or Salmon. The skins are used by the Laplanders, cooked into a kind of jelly, and for making glue; and in the village of Lisse, on the Haarlem-mere, celebrated dishes are prepared from their milts; while of their scales, whitened and cleaned, many pretty ornaments have been lately made.

The general habitat of the Perch in Britain is in lakes, and streams not too rapid. They delight in a clear bottom with grassy margin, or in rivers overhung with brush, and widening into some beautiful lake-like expanse. Here they roam in shoals, descending and rising, seeking their food, and shading themselves trom the too great heat among the reeds or foliage. They are rather a 
stupid fish, and are easily taken with the rod at various baits - the most successful of which is, however, a Minnow. In streams where they have grown large, they afford tolerable sport; and, from the shoal feeding in company, many may be taken when it is once discovered. The average size may be stated at from one pound to a pound and a half. Those of three and four pounds are, however, tolerably common; but the one mentioned by Pennant, to have been taken in the Serpentine river, of nine pounds, appears to be still the largest upon record.* In some of the Highland lochs, particularly those of Perthshire, they are remarkably fine and abundant.

Pallas gave the title of Labrax to a race of fishes found in the sea of Kamtschatka, remarkable in having several lateral lines or rows of pores upon the sides; but Cuvier, thinking the name inapplicable to a fish which was not known to the ancients, has applied it as a subgeneric title in his own arrangement, to the Perca labrax of Linnæus. This explanation is necessary, lest the present sub. genus should be confounded with that of Pallas,

- Bloch mentions one taken in Siberia, of which the head alone measured eleven inches in length, and was kept as a curiosity. The weight must have much exceeded those above mentioned. 
and it will remain optional with systematists to retain it here, or in its former place. It differs from Perca, in having scales upon the opercles, absence of teeth on the subopercles, inter-opercles, and suborbitary bones, by the double spine upon the opercles, and by the very small close set teeth which cover the greater part of the tongue. The most common species is 


\section{THF BASSE, OR SEA PERCH}

Labrax lupus. _Cuv.

\section{PLATE II.}

Perca labrax, Linnoeus. Bar commun, Labrax Jupus, Cuv. et Valen. Hist. Nat. des Poissons, i. 56. - The Basse, Pennant._Donovan, plate xliii.
B. 7;
D. 9-1.12;
A. 3.11 ;
C. $17 ;$ P. $16 ;$ V. 1.5 .

This fish, by most writers on the British species, is said to be tolerably common on the coasts of the south of England during the summer, while, on the Dutch side, there are established fisheries of it. It was well known to the ancients, and is mentioned by many of their poets. It was celebrated as well for the excellency of its flavour, as for the stratagems it used when encircled by nets, or fastened by the hook. Its general length is from ten to eighteen and twenty inches, though it is said to grow much larger. The specimen, however, mentioned by Duhamel, as thirty pounds in weight, Cuvier thinks he must have mistaken for some other fish, but seems to have less doubt of those which have been recorded of fifteen and twenty pounds in weight, having received one from Abbeville three feet in length. The form 

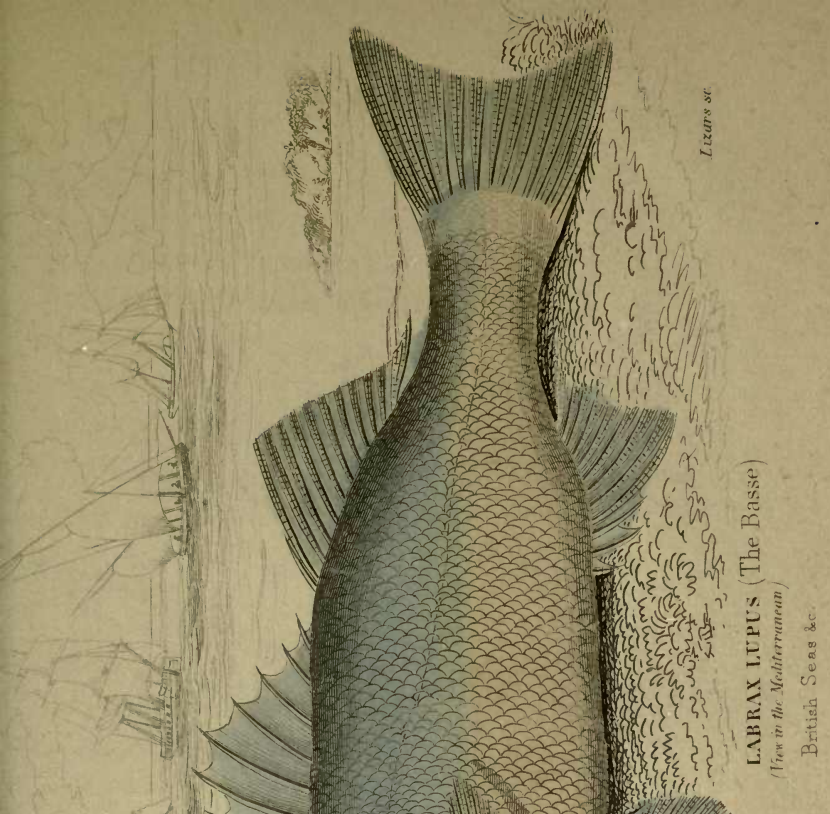


\section{REESE LIBRA PPY UNIVERSITY}

\section{CALIFORNIA.}


of the Basse is of considerable elegance, and the colours are chaste and pleasing, without any of the striking contrasts we have in the true Perches. The upper parts are gray, with bluish reflections, which gradually shade into a silvery white on the lower parts; the fins are gray, the pectoral ones slightly tinged with reddish. At some periods they appear to be marked with spots or clouds, wnich was attributed to be the colouring of the young only; Cuvier, however, found very small specimens perfectly unspotted, while some of the larger were the reverse, and he is more inclined, from his observations, to consider it a sexual difference. The extra European species amount to only four or five: to them belong the Rock-fish, or Striped Basse of the AmericansLabrax lineatus, Cuvier - abundant in the vicinity of New York, where it is much esteemed, and brought to the markets of a weight reaching sixty and seventy pounds. They ascend the rivers in the spring to spawn, and are then taken in immense numbers with the hook.

Another species was discovered in the bay of Offack in the island of Waigiow, by Lesson and Garnot, the naturalists to the expedition of Duperry. It is of small size, of a golden green, with brownish lines. Another species inhabits the Japanese seas.

The next sub-genus of Cuvier is very closely 
allied to this. The sub-orbitary bone only is toothed; the preopercle has a spine at the angle, and very strong teeth upon the lower surface. The first dorsal fin is higher and shorter than in Perca labrax, and the tongue is free as in the Perch. They are in general a wholesome fish, of a large size, and inhabit the rivers of the warmer parts of the old continent. Lates, now adopted for the genus, was the ancient name given to some of the species. That which we shall notice is, 


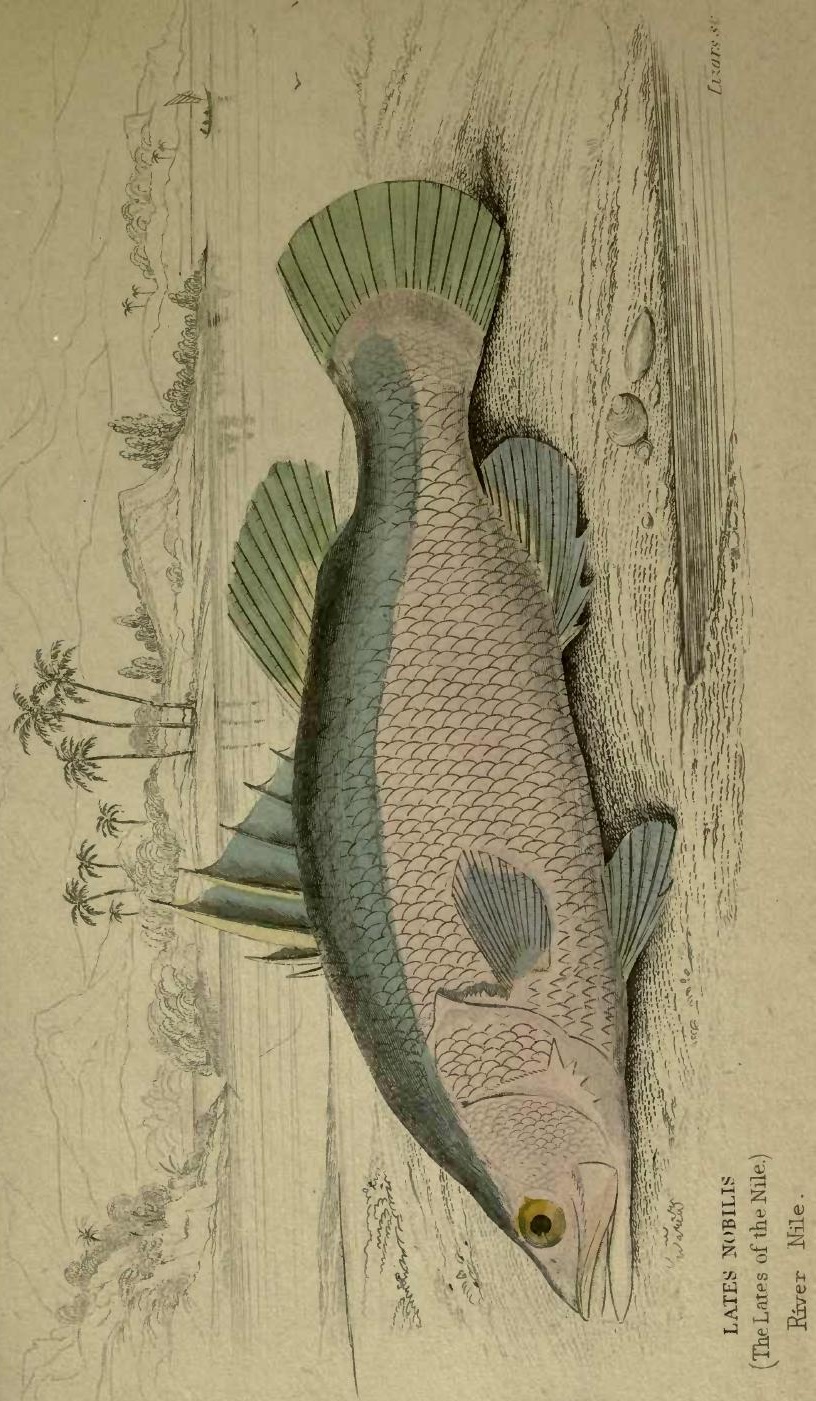


REESE LIBRADY

UNIVERSITY

CALIFORNIA. 


\title{
THE LATES OF THE NILE.
}

\author{
Lates Niloticus._Cuv. et VAL.
}

\section{PLATE III.}

Perca Niliotica, Linnceus. - Le variole du Nil, Late Niloticus, Cuv. et Valen. Hist Nat. des Poissons, ii. p. 89. Keschr, or Keschere, of the Arabs.

B. 7; D. 7 or 8-1.12; A. 3.8 or 9 ; C. 17 ; P. $15 ;$ V. 1.5 .

THis fine fish appears to have been known to many of the ancient writers, who agree, generally. in giving it a very large size, so far as three hundred pounds weight; this, however, is unknown at the present time, and species of a much less size are only seen. It is also universally acknowledged as one of the most delicate and best flavoured fishes of the Nile. The Lates of the Nile approaches Labrax in the absence of spines on the sub and inter-opercles, but it resembles the Perch by the single spine on the opercle, and the teeth on its sub-orbitary bone. The form, however, approaches nearest to the Perch. There are also four or five strong spines upon the super scapular bone, and five still stronger on the angle of the humerus above the pectoral fin; but these teeth or spines become 
effaced in the old and large species, and in those of three feet long, are scarcely perceptible. The spines of the dorsal fin are remarkably strong, particularly the third; those of the dorsal fin are very rigid, and with the tail and other fins are of considerable power. The scaling is rather large, and rough on the edges. The lateral line seems nearly parallel with the back, at about one third of the depth, and on each scale there is a narrow and slender tube. The whole fish is of a silvery tint, tinged with olive brown on the upper parts and fins.

Another fish which Cuvier places in this sub-genus is, the "Cock up" of the English at Calcutta, the Caires vacti of Hamilton Buchanan, and the Lates nobilis of our author. It is one of the lightest and most esteemed foods brought to table in Calcutta. The Vacti abounds in all the mouths of the Ganges, which it ascends as far as the tide, and follows this into the marshes, ditches, and ponds; but those found in salt water are of by far the best quality, as are those about two feet in length. It is often caught five feet long; but when it approaches this size the taste becomes strong, and when small, it is rather insipid. The upper parts are of a green colour, with a gloss of gold and purple; the lower parts are silvery.*

- Ham. Buchanan, Gangetic Fishes, p. 87. 



\section{ELEVEN-SPINED CENTROPOME.}

Centropomus undecimalis.-LACEP.

\section{PLATE IV.}

Centropome undecimal, Lacepede.-Sciena undecimalis, Bloch, 305, Auct. Cuv. - Le Centropome brochet de mer, Centropomus undecimalis, Cuv. et Valen. Hist. Nat. des Poissons, ii. p. 102.

$$
\text { B. } 7 \text {; D. } 8-1.10 \text {; A. } 3.6 \text {; C. } 17 \text {; P. } 15 \text {; V. } 1.5 \text {. }
$$

LACEPEDE formed the present sub-genus for the reception of the subject of the accompanying plate, the principal distinctions of which are taken from the gill covers, and is named from having eleven spines in the last dorsal fin. It is abundant, and forms a large article of consumption in most parts of South America, in the French, Spanish, and Portuguese colonies; at Rio de Janeiro, Lima, and Cuba. It frequents the mouths of rivers, and even runs so far up as in some parts to be counted a fresh water species. It is every where much esteemed, appearing at the tables of the most opulent. It reaches a weight of above twenty-five pounds, and in the markets is sold in cuts or pieces, like many of the larger fish in this country. A kind of caviar is made from the roes. 
From the flattened muzzle and general form of this fish there is some resemblance to the Pike, under which name, with the addition of "sea," it is in some places known. The head is narrow, and when viewed from the side, it appears still more lengthened, from the elongation of the lower jaw, which considerably exceeds that of the upper. The cheeks, opercles, and sub-opercles, are covered with scales. The dorsal fins are triangular, and separated by a larger space than we have yet seen, being in reality distinct. The first has eight, the second eleven rays. The scales are nearly round, rough upon the edges. The lateral line undulates a little near the centre of the fish, is very conspicuous, and forms a black line running the whole length of the body; it is formed by a wide and short tube pierced in each scale. The colour of the fish is silvery, tinted with brown, or greenish on the upper parts, and relieved by the deep tint of the lateral line. The first dorsal fin is gray, the others yellowish, finely dotted with black on their edges.

The next sub-genus has been named by Cuvier Lucioperca, or Pike-perch, from the combination which its type exhibits of the characters of the two fish. It possesses the fins and banding of the latter, with the elongated form of the head and body, and the sharp long teeth of the Pike. The best known species is 


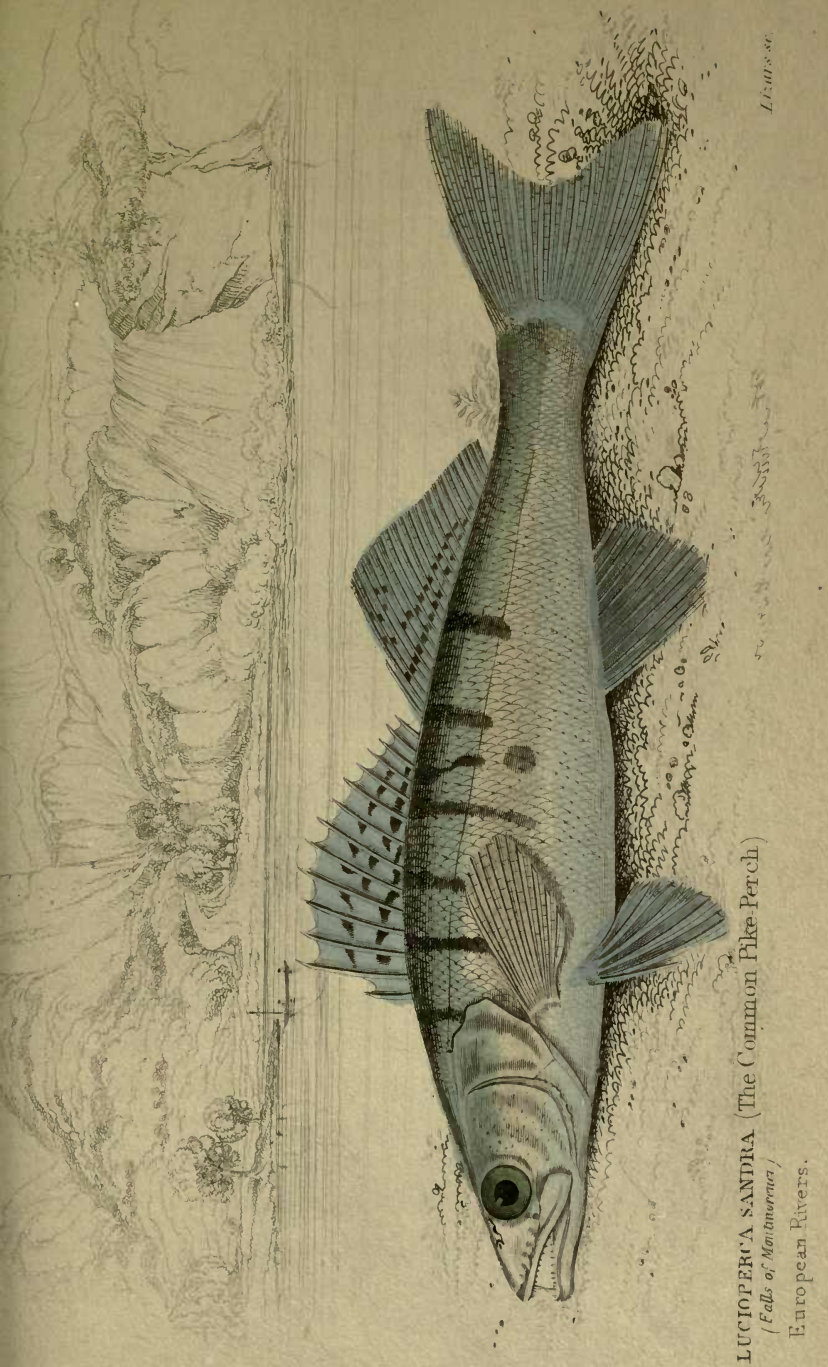




\section{REESE LIB UNIVERSITY}

CALIFORNIA. 


\section{5 \\ REESE LIBRA \\ TT OF THE \\ UN IVERSITY \\ THE COMMON PIKE-PERCH.}

Lucioperca sandra._Cuv. et VAL.

\section{PLATE V.}

Perca lucioperca, Bloch. - Le Sandre commun Lucioperca sandra, Cuv. et Valen. Hist. Nat. des Poissons, ii. p. 110.

D. $14-1.22$; A. 211 ; C. 17 ; P. 15 ; V. 1.5 .

Tris handsome fish inhabits the rivers and lakes of the north and east of Europe, but, according to Cuvier, is unknown in Italy, France, or Britain. It is taken in the Danube, the Elbe, and the Oder; in the Baltic, Caspian, and Black Seas, the Sea of Asoph, and is very abundant in the Volga. In this great European range, and notwithstanding its excellence as food, it appears to have been unknown to the ancients; at least none of our most skilful ichthyologists have been able to trace its presence as an article of luxury or necessity at their entertainments. It is a fish of rapid growth, and attains a length of three to four feet, and a weight of twenty pounds. Its flesh is of an agreeable taste, rich, and, when cooked, remarkably white. It is often salted and smoked, and quantities prepared in these ways are exported from both Prussia and Silesia. It 
is extremely prolific, three hundred thousand ova, of about a size equal to a grain of mustard, occasionally forming the roe of a single fish. It is, at the same time, a much more tender fish than the Perch, and will not bear carriage in the same way; and it is this which, Cuvier thinks, has hitherto prevented its introduction into France, where there is no remarkable difference in climate from the countries in which it is so abundant. Would it not be possible to introduce it to some of the British waters?

The general colours of this fish, though less gaudy than those of the Perch, are chaste and simple; the back and upper parts are of a greenish gray, changing, on the sides and belly, to silvery white. In the old fish, the upper parts have dark clouded spots, but which, in the young, take the form of vertical bands. The dorsal fins are gray, and have black spots between the rays, which are so distributed as to form bands across. In the young, these spots are more clouded, and are also sparingly scattered over the head and tail. The other fins are greenish gray, in some individuals tinted with yellow. The teeth are in general small, but thick and close set; two on the upper jaw, four on the lower, and twe on the fore part of each palatine bone, are of a larger and more iormidable size. The internal structure of this fish nearly resembles that of the Perch. 
Cuvier enumerates two additional Russian species, which seem first to have been noticed by Pallas. The one, from the Volga, has received the specific appellation of Volgensis, and rests on the authority of Pallas alone, Cuvier not having seen a specimen. The other, L. marina, Cuvier and Valenciennes, found in the Black Sea, possesses a flesh firm, white, and of great delicacy. This, as a species, seems also yet imperfectly known. America possesses another of a greenish yellow, or spotted over with blackish, and is the Lucioperca Americana, Cuvier. 


\title{
THE BLACK BASS OF THE HURON.
}

\author{
Huro nigricans._Cuv. et VAL.
}

PLATE VI.

Le Huron, Huro nigricans, Cuv. et Valen. Hist. Nat. des Poissons, ii. p.124.

IN the arrangement which Cuvier has proposed, some fishes were occasionally met with which could not enter into the genera already formed. while they evidently were closely allied to them; his plan here seems to have been to arrange them at the termination of those of whose situation he had no doubt; and such is the case with four curious species which occupy as many of our following plates. The first is the Black Bass, or Black Perch of the English residents on the banks of the Huron. Its flesh is firm and white, and it is much esteemed during summer. The upper parts of the fish are of an olive brown, changing into yellowish white on the belly, and along the central ridge of each scale is a line of the same colour with the upper parts, giving it a striped appearance on the sides. The body is rather deep in proportion, the under jaw slightly projects, and the head, cheeks, and opercles are scaled. The teeth are nearly similar to those of the Perch. 


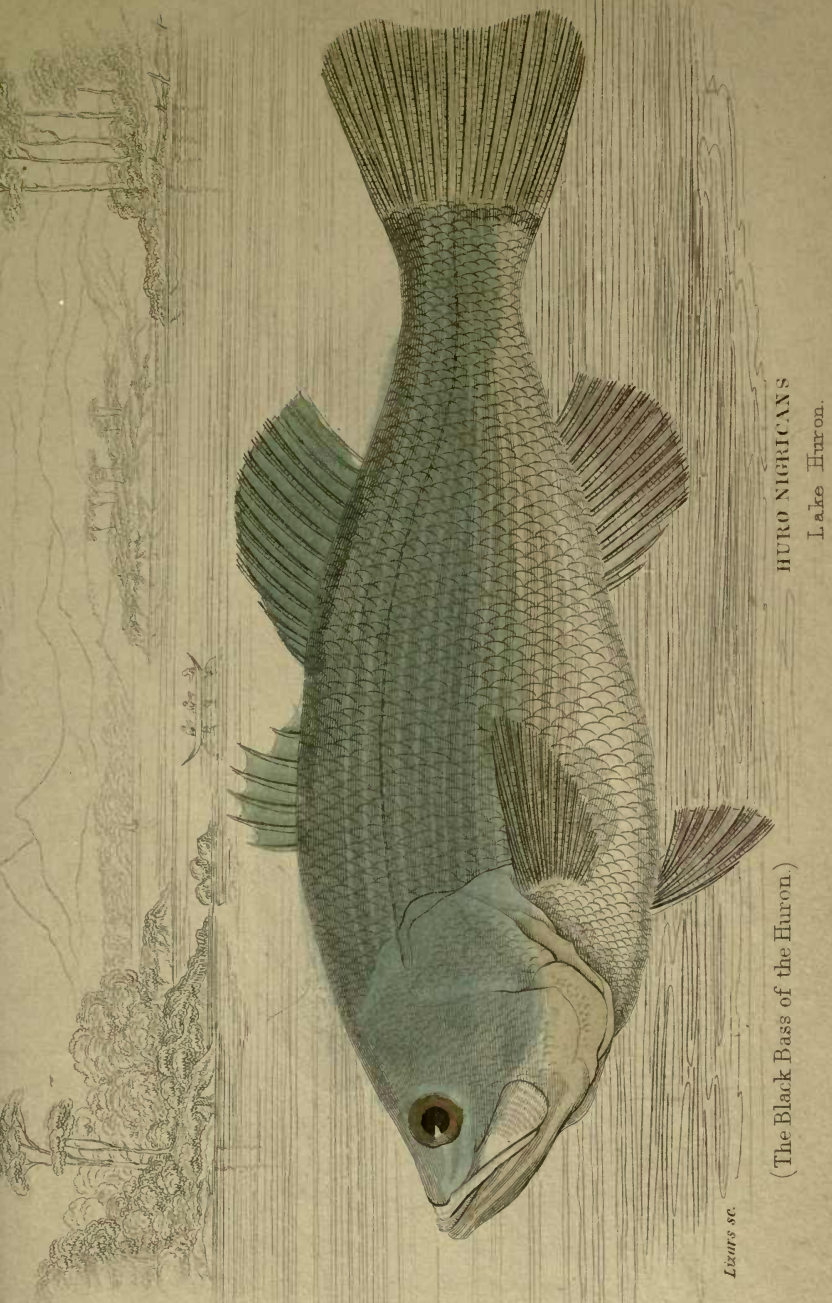




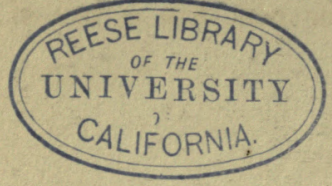
OF THE
CIV ERSIT
CALIFORNIA. 


\section{THE BLACK BASS DF THE HURON. 109}

The first dorsal is much less, contains only six rays, and is placed at a considerable distance in front of the second. The anal fin is again considerably larger in proportion, and has three spiny, with eleven soft rays. The others are nearly similar to those of the Perch.

Cuvier's specimen was sixteen inches in length; and although the fish is esteemed, and seems abundant in its native country, little is yet known regarding it. Our next fish is one of great beauty-it is 


\section{THE RUBY-COLOURED ETELIS.}

Etelis carbunculus.-Cuv. et VAL.

PLATE VII.

L'etelis, Cuv. et Valen. Hist. Nat. des Poissons, ii. p. 127

B. 7 ; D. $9-1.11$; A. 3.8 ; C. 17 ; P. 16 ; V. 1.5

THis genus is also formed from a single specimen, taken by M. Desumier near the Sechelle Islands. and from the beauty of its colouring, which Cuvier compares with the tints of the ruby, has received the specific name of Carbunculus. It differs from the Perches in possessing strong and long teeth, by which it approaches to the structure of Lucioperca, but other parts of the teething here also differ; the opercle is terminated by two spines.

The eye of this splendid fish is a conspicuous object, and is of a golden orange. The scaling is large and marked, and the whole ground colour of the fish is bright ruby red, relieved by stripes of golden yellow, which run along the ridges of the scales. The length of M. Desumier's specimen was about eleven inches. 



\section{THE. SPINED NIPHON.}

N.eflems spinosus._Cov. et Vac.

\section{PLATE VII.}

Le Niphon, Cuv. et Valen. Hist. Nat. des Porssons.

D. $12-1.11$; A. 3.7 ; C. 17 ; P. 16 ; V. 1.5 .

INHABITS the Japanese seas, and is remarkable for the strong and formidable knife-like spines with which the opercles are armed; indeed, the whole head is sawed and spined in a singular manner. The sub-orbitary bone has the lower edges like a fine saw; the preopercle is sawed on its posterior edge, and strongly toothed below; while at the angle is a large and strong daggerformed spine, exceeding in length the edge of the opercle. Upon the opercle itself three spines rise edgeways from the surface. The super-scapulary bone has two teeth, and the humerus above the pectoral fin is furnished with a flat spine. The first dorsal fin, the ventral, and anal fins, are also all strongly spined, and complete the array of this well defended species. The upper parts are of a pale brown colour, the lower parts silvery, the dark shade of the upper part is divided, in a line from the eye backwards, 
by a pale longitudinal band. The upper fins are grayish, the last dorsal fin with a blackish spot on the fore part. The others are of a yellowish white, and the tail is blackish at its two angles, with a central paler line. In lengtl, the single specimen, whence the description was taken, was about eight inches.

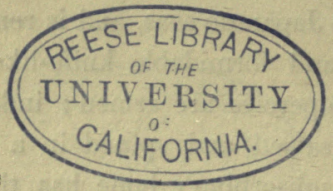




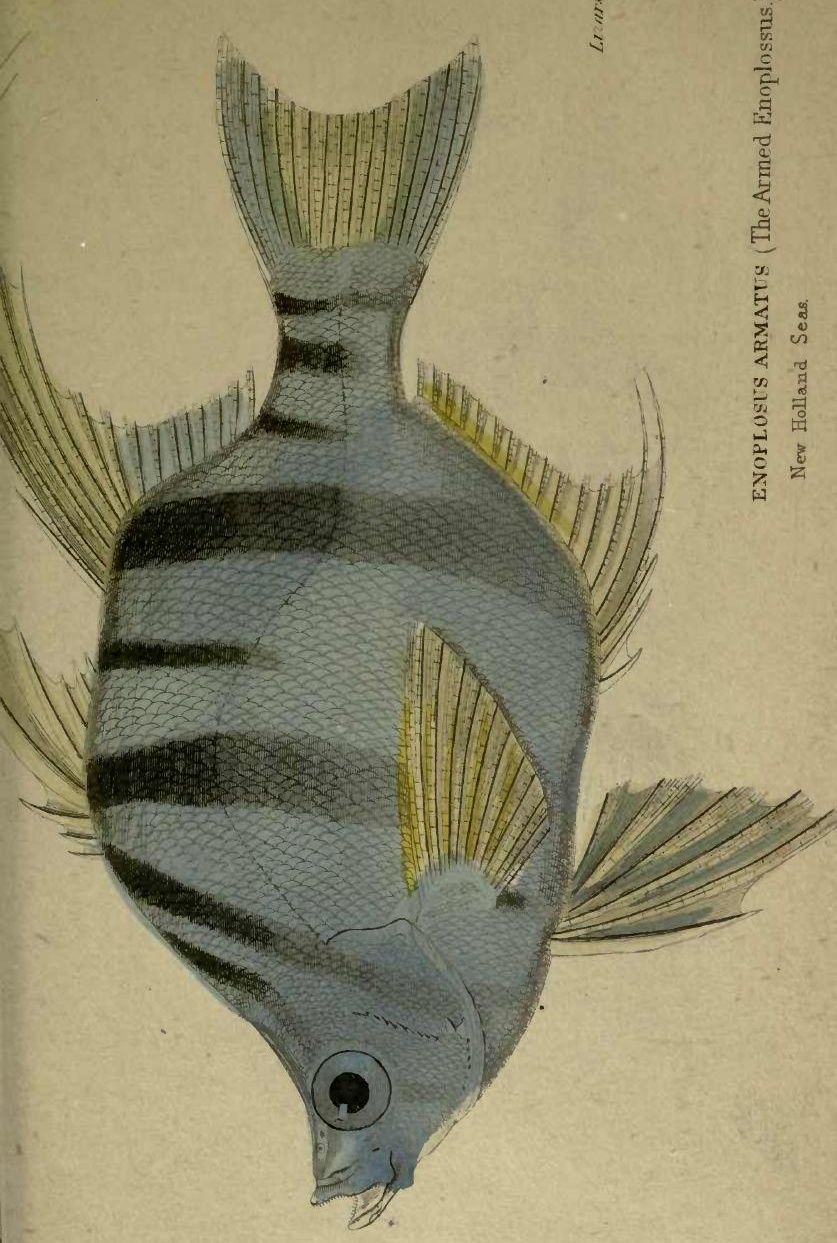




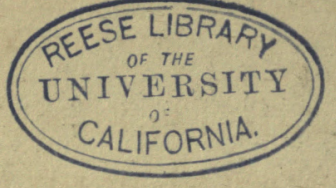




\section{3

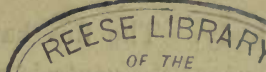 \\ UNIVERSITY \\ CALIFORNIA. \\ THE ARMED ENOPLOSSUS.}

Zinopiossus armatus._LACEP.

PLATE IX.

Long spined Chætodon, Chætodon armatus. Whete's

Vayage to New South Wales, App. p. 254.-Enopiossus, Lacepede. - L'Enoplose, Cuv. et Valen. Hist. Nat. des Poissons, ii. p. 133.

B. 7 ; D. 7-1.14, or 1.15 ; A. 3.15 ; C. 17 ; P. 12 ; V. 1.15 .

THis, with the next fish, are very remarkable in their forms as coming into the present family. At first sight they appear to be something quite different, but, on examination, the characters of the percoid fishes are very evident. The fish represented on Plate IX, so much resembles a Chætodon in form, (being nearly as deep as long,) that it has been placed with them, and the dark banded markings and lengthened rays of the fins bring it even nearer in resemblance; but the teeth, the want of the scaling at the base of the fins, and the internal structure of all parts, differ. The colouring is chaste, but distinct and well marked, the ground shade entirely of a silvery gray, palest on the belly, and relieved by eight narrow black bands, which either entirely or in, 
part surround the body. The fins have a yellowish appearance, except the ventrals, which are blackish, of which colour, or rather of a deep gray, are the membranes between the spines and rays of all the fins.

It is abundant in the New Holland seas, but appears to reach no great size, eight or ten inches in length being the greatest which have yet been seen. 
QEESE LIBRARY UNIVERSITY

CALIFORNIA.

a. 


\section{TWO BANDED DIPLOPRION.}

Diploprion bifasciatum._KoHL. et Von HassezT.

PLATE X.

Le Diploprion, Cuv. et Valen. Hist. Nat. des Poissons, i. 137.

\section{B 7; D. $8-15 ;$ A. 2.12 ; C. $17 ;$ P. $17 ;$ V. 1.5}

THIs singular looking fish was discovered on the coast of Java. The body is compressed, the head very large, and nearly the depth of the body, from whence the shape tapers towards the tail. The opercle is armed with three strong spines, and the preopercle has the edges toothed and serrated. The first dorsal fin is large and powerful, and contains eight very strong rays. In the other fins nothing remarkable is seen except in the ventrals, whose first and second rays are long, and extend beyond the commencement of the anal fin. The scaling is very minute. The colours are a fine reddish yellow, relieved by two crossing bands of black, the one through the eye, the other from the termination of the first dorsal fin, obliquely, to the anal ; the first 
dorsal fin is brownish black. This fish is only known of about six inches in length.

The next genus contains numerous species. That we have to notice, is

REESE LIBRA 


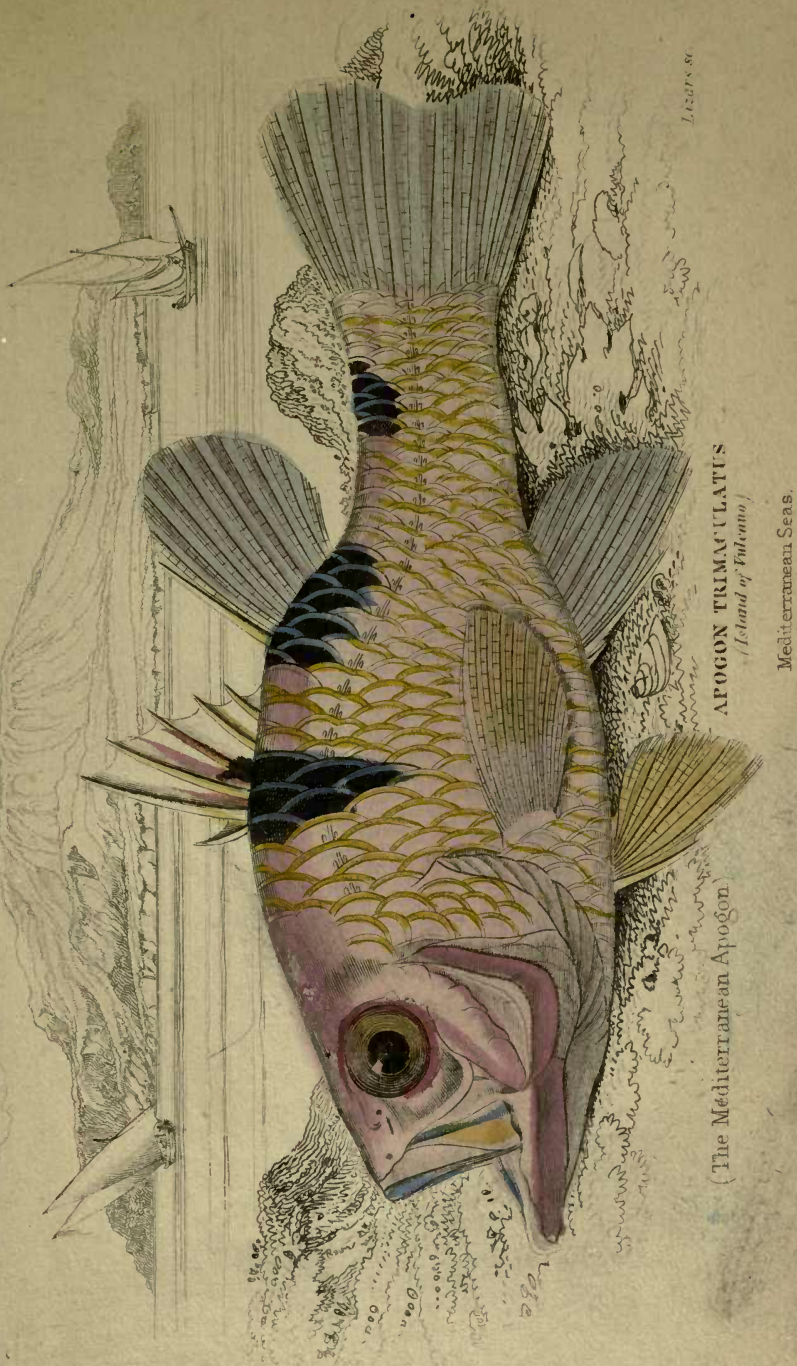




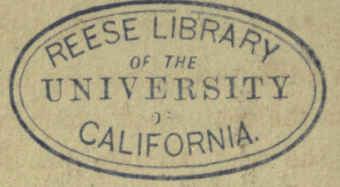




\title{
THE MEDITERRANEAN APOGON.
}

\author{
Apogon rex Mullorum. - Cuv, et VAL.
}

PLATE XI.

Apogon commun, vulgairment Roi des Rougets, Cuv. et

Valen. Hist. Nat. des Poissons, ii. p. 143.

D. $6-1.9 ;$ A. 2.8 ; C. 19 ; P. 10 ; V. 1.5 .

APOGON is a title established by Lacepede for this fish, from the connection which he supposed it bore with the true Mullets, but from which Cuvier is of opinion it is considerably removed. The members of the subgenus are distinguished from any we have yet seen by the largeness of their scales, which, in reality, resemble those of the Cyprini. They, however, come very easily off, like those of the Mullets. The dorsal fins are far separated. The preopercle has a double edge, finely toothed. In the internal structure they bear a greater resemblance to the Perches than to the Mullets.

The Common Mediterranean Apogon has been subject to much confusion of synonymy, which $\mathrm{M}$. Cuvier has entered into at length in his history, but which it is unnecessary to introduce here. It is the only species found in the Mediterranean, and is taken at Marseilles, Nice, Ivica, Naples, 
Palermo, and Malta, during the spawning season, in June, July, and August, when it approaches the shores. At other times, like similar migratory fish, it most probably withdraws to the deeper recesses of the ocean. It is much esteemed at table.

This little fish scarcely exceeds six inches in length. Its body is short, moderately compressed, somewhat swollen in the centre. The preopercle has its edge finely serrated; but the peculiar character in these fish is the double edge, or kind of second ridge, which rises on the preopercle, and of which a slight trace was observable in the Centropomus undecimalis of Plate IV. On the opercle there is a small spine on the posterior edge. The colours of this gaudy little fish are in general a crimson red, paler on the lower parts, and relieved by three deep black markings, one at the base of each dorsal fin, and a third about midway between the last and the insertion of the tail. The tint of the general colour is sometimes of a much yellower hue, according to the season, sometimes almost yellow; and there is little doubt that the brilliancy is much heightened at the time when the spawn is near its perfection. The whole surface is scattered over with small black spots or dots, most conspicuous on the 
cheek and gill covers.* The dorsal fins are separated, though by a less space than those of the Mullets; the first narrow, and with strong spines. The others nearly resemble those of the Perch.

The foreign species seem mostly confined to the Indian seas, and none have yet been found in those belonging to America or Africa. A few have been met with in the New Holland seas, New Guinea, \&c. particularly in the late voyages under M. Frecynet. Many of these fish are of brilliant colours, principally red and yellow; but even the more sombre marked have some decided contrast in dark coloured bands or spots, or in some markings of the fins. They all appear to be of small size; the largest which is known being only about seven inches in length. The Apogon trimaculatus of Lesson and Garnot is of a golden red, relieved by three black marks, placed on the dorsal fins, and on the tail. Others, again, have the dark markings in longitudinal stripes; such is the Apogon quadrifaciatus of a silvery red, with two dark brown bands on each side of the back; another, from the Isle of Guam, is striped with nine black bands, whence it has the name of Apogon novemfaciatus.

- This minute spotting is not represented in the copy of our plate. 


\section{ARABIAN CHEILODIPTERUS.}

Cheilodipterus Arabicus, Cuv. et VAL.

\section{PLATE XII.}

Le Cheilodiptere Arabique, Cuv. et Valen. Hist. Nat. des Poissons, ii. p. 165.

B. 7 ; D. $6-1.10$ or 1.9 ; P. 14 ; V. 1.6 ; A. 2.9 or 1.8 ; C. 17 .

Tre Arabian Cheilodipterus illustrates another genus of Lacepede, formed from one of Commerson's fishes, and bearing the same relation to Apogon, which Lucioperca does to the Perch. The double edged preopercle, finely serrated; the two dorsal fins far removed, and the scaling large, but easily rubbed off; while a portion of the teeth are long, sharp, and rather strong. The fish represented on Plate XII. is a native of the Red Sea, where it is frequently taken by the Arabs. The colour of the upper parts is a fresh olive green, changing on the sides and belly to silvery, deeply tinted with a reddish or rose colour. The whole body is marked longitudinally with dark lines, somewhat following the bend of the fish, and amounting in number to from fourteen to seventeen. At the insertion of the tail there is a cross band of the same colour 


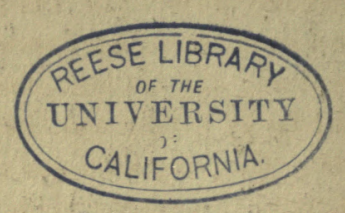


as the back, shading at the edges into yellowish, and in the centre of it, as terminating the lateral line, there is a round black spot. The fins are of a grayish tint, nearly formed as in the preceding fish, the first dorsal with the anterior and upper edge black. These fish seem also to reach only a small size, and all those which are yet known are banded longitudinally, as that now described. Three species only are noticed. The first has eight bands ; the second, as we have seen, from fourteen to seventeen; and the last, discovered near the Society Isles by. Lesson and Garnot, has five black bands. C. quinquelineatus is only four inches in length, of a silvery white; the stripes of deep black.

Our next fish is very remarkable: it is 


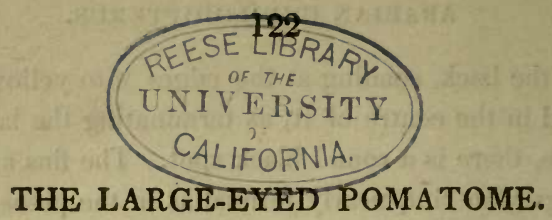

Pomatomus telescopium._Risso.

PLATE XIII.

Des Pomatomes._Cuv. et Valen. Hist. Nat. des Poissons, ii. 169.

D. $7-1.10$; A. 2.9 ; C. 17 ; P. 18 ; V. 1.5 .

THIs fish, according to M. Risso, is very rarely taken, never almost leaving the bottom of the deep sea. At Nice he was only aware of two specimens being taken during thirty years. The flesh is well-tasted, tender, and firm. It is remarkable for the immense size of the eyes, which occupy nearly the whole cheek, and is an example of that form of the organ, which we mentioned (p. 74) occurred in those species which generally kept at a depth beyond the penetration of the sun's rays, and which might be called nocturnal. Whether its sight is acute, or what peculiarities there are in the structure of the eye and its other organs, is yet a desideratum among ichthyologists, the rarity of the species having hitherto prevented examination. The cheeks and opercles are covered with scales; the form of the preopercle is remarkable in the 

projection backwards of the lower angle, and neither it nor the opercles are armed with teeth or spines. The colours are a brownish violet, with blue and red reflections; the fins of a brownish black. These are of middling size, except the tail, and present nothing very remarkable. The tail is expanding and very ample, considerably forked. The length of the specimen taken at Nice by M. Risso was about twenty inches. 


\section{COMMERSON'S AMBASSIS.}

Ambassis Commersoni._Cuv. et VAL.

\section{PLATE XIV.}

Des Ambassis, Cuv. et Valen. Hist. Nat. des Poissons, ii. 175. -Genus Chonda, Hamilt. Buchan. Gang. Fishes, 103.
D. 7-1.9;
A. 3.9 ;
C. 17 ; P. 12 ; V. 1.5 .

Ambassis is distinguished by the protracted mouth, the toothing of the suborbitary bone, by the double edge extending round the preopercle, the serrating of the lower edge, and by the small nearly concealed spine at the insertion of the first dorsal fin. They seem to inhabit the tanks, salt marshes, and pools of India, and to fill the same place in the Indian ichthyology with some of the small Cyprini and Sticklebacks of Europe. The concealed spine is an approach to the latter. According to Hamilton Buchanan, they are all very small and of little value, although in many places abundant, and used in considerable quan. tities; but as food they are insipid, and filled with small bones, for which defects their size does not compensate.

That which Cuvier has taken to illustrate the genus is Commerson's Ambassis of the accompanying plate, one of the largest of the genus, 


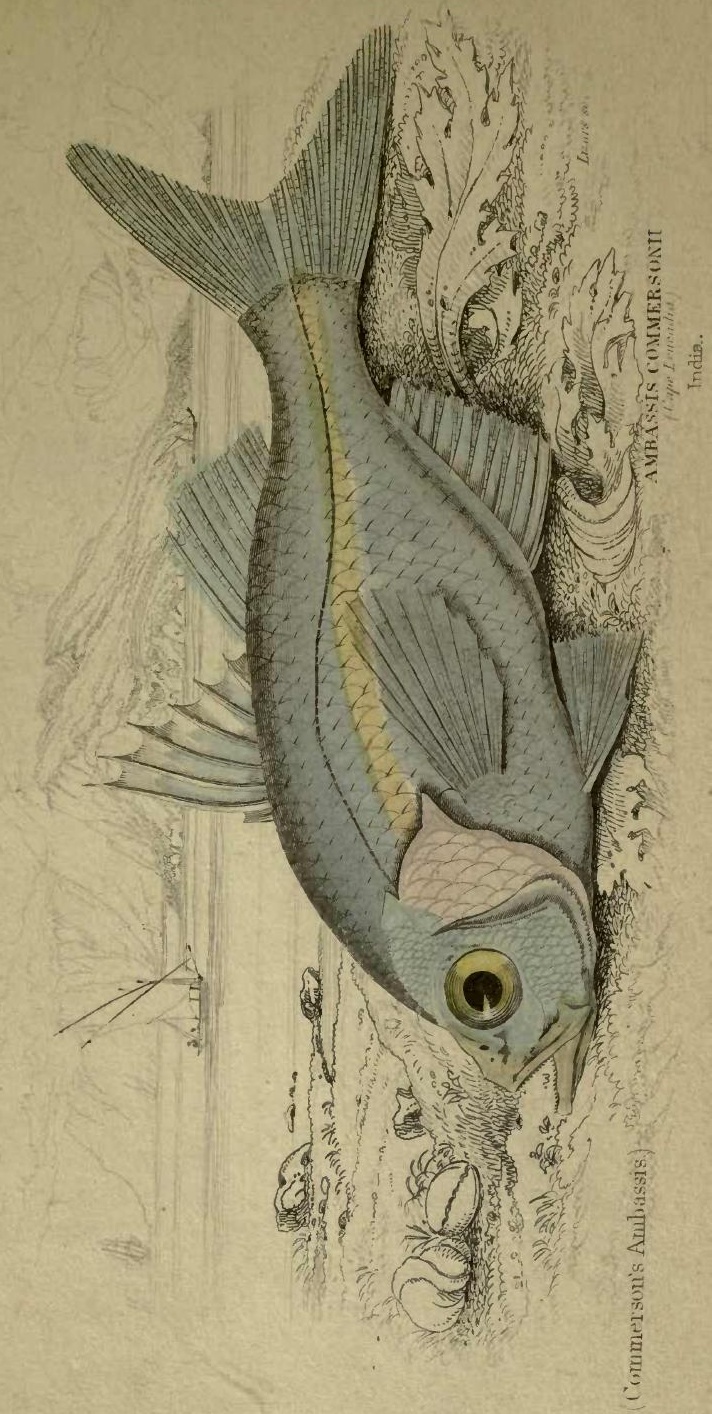




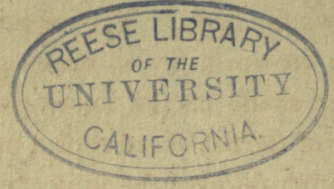


plentiful in the seas around the Isle of Bourbon, and found also at the mouths of the Pondichery river on the coast of Malabar, and in Java. In the island of Bourbon it is relished in soups, and sometimes preserved in pickle; and the fishing of them gives employment to many of the inhabitants.

It is a handsome and rather beautiful fish when fresh taken from the water, a silvery tint overspreading the whole body. The upper part of the back is of a brownish green, which gradually falls into a paler shade on the lower parts; and along the centre of the fish there runs a pale broad shining line, which relieves the uniformity of its colouring. The principal parts to be examined here are the serrating of the under edges of the preopercles and the first dorsal fin; the first ray is very short, the second the longest; but before either there is a small lying spine, not seen in the figure, and which can only be discovered by feeling with the finger. This fish is about seven inches in length. There is a peculiarity in the ribs of this species mentioned by Cuvier; it commences with the third pair, and each of the eight following have their upper half dilated into a small oval plate, with a longitudinal groove on the outward surface, which runs in a line with the slender part of the bone.

There are several other species of this genus 
but they are all of little comparative interest. The A. nama is common in ponds throughout Bengal, and seldom exceeds three inches in length. $A$. baculis is found in the north-eastern parts of Bengal, and seldom exceeds an inch and a half in length; while the $A$. ranga of a similar size is found in the fresh waters of all the Gangetic provinces. The whole of these pretty little fish are diaphanous in the structure of the skin and sides, that the muscles, ribs, and even the intestines, can be traced; and the intensity of their bright colouring is from this cause considerably weakened. 
a.

REESE LIBRAAP

UNIVERSITY

CALIF́ORNIA. 


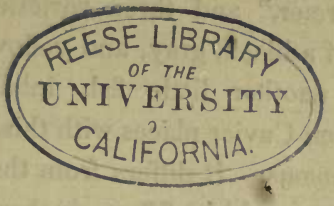

THE ZINGEL.

Aspro vulgaris.-Cuv. et VAL.

\section{PLATE XV.}

Perca asper, Linnaus, Bloch.-L'apron properment dit, Cuv. et Valen. Hist. Nat. des Poissons, ii. p. 188.

B. 7; D. 8-1.12; A. 1.12; C. 17; P. 14; V.1.5.

The little fish forming this genus is at once distinguished by the lengthened form of the body, and by the situation of the mouth, which is almost placed under the snout or nose, that part being rounded and projecting over it ; it is also remarkable for the roughness of its scales, whence by Rondoletius it was said to receive its name of Asperus. It is found in the Rhone and its tributaries, but is not known in the rivers on the west of France. It is also said to be found in the Danube, while other ichthyologists assert, that it is to be met with in some of the Russian streams. It seldom exceeds six or seven inches in length, but is used at table, and is esteemed good and delicate. By the fishermen of the Rhone, it is 
termed "Sorcier," and three varieties are distinguished, of a black, gray, and yellow colour.

There is another little fish inhabiting the Danube, which Cuvier places with this, the Perca zingel of Linnæus, It differs from the former in its larger size, reaching fifteen inches in length, and a weight of two or three pounds, and by the greater number of rays in the dorsal fins. The colour of the back and sides are of a grayish yellow, that of the lower parts whitish; four clouded bands of a brownish black descend obliquely from above, and mingle with dots and spots equally clouded upon the sides; the muzzle and opercles are brownish, and on the cheeks there are some brownish black bands. These are the only known fishes which approach to this form. 


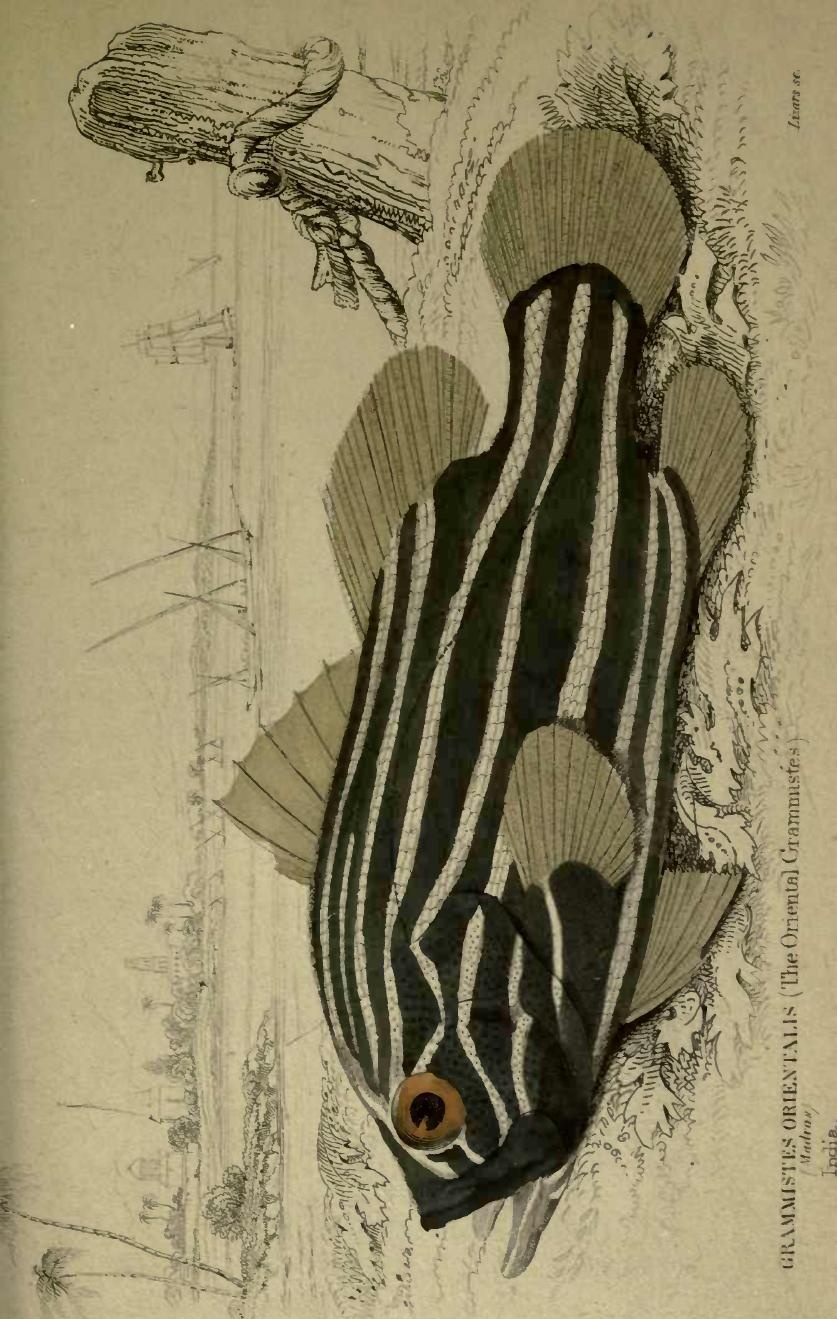




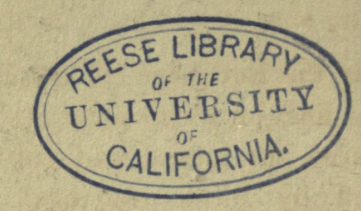$$
\text { REESE LIBRARY }
$$$$
\text { UNIVERSITY }
$$$$
\text { CALIFORNIA. }
$$ 


\section{THE ORIENTAL GRAMISTES.}

\section{Gramistes orientalis._BLOCH.}

\section{PLATE XVI.}

Gramistes orientalis, Bloch._-Le Gramiste oriental, Cuv. et Valen. Hist. Nat. des Poissons.
D. $7-1.13$; A. 3.8 ; C. 17 ; P. 14; V. 1.5 .

Gramistes is the last genus of the Perches with two dorsal fins, or where there is a visible separation between the spined and soft parts. That established by Bloch contained several species; by Cuvier, however, it is restricted to the fish of the accompanying plate, the only one yet discovered. It approaches nearest in structure to the Rypticus arenatus of Plate XXX, but is at once distinguished by the double dorsal fin. The present fish was described long since in the work of Seba. It is of small size, not exceeding five or six inches, and, when newly taken from the water, seems without scales, which are very sinall, but appear on the skin being dried. The opercle has three short spines. The markings of this fish are very singular: the sround colour is a brownish black, with longiw:tinal lines of white on each side, generallv 
seven in number, with a single one along the back, and another along the belly. On the opercles and cheeks they form a sort of network. The fins are yellowish. In some specimens, the number of lines varies; and two or thise species have, on that account, been made of them. These, however, Cuvier, is inclined to consider as all belonging to one, and cites a specimen having seven lines on the one side and eight on the other. In the internal structure, it goes off from the Perches we have yet seen, and approaches that of some of the first divisions of the next section, the 


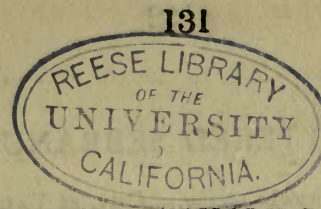

PERCHES WITH A SINGLE DORSAL FIN.

WE now come to the second great division of the Percoid Fishes, characterized and known at first sight by the simple character of a single dorsal fin, no separation appearing between the spiny and softly rayed part. The sub-divisions, it will be seen, are taken from the opercle, preopercle, teeth, and jaws. The first genus is Serranus, containing a numerous series of species, almost all of them remarkable for the beauty of their tints and singularity of marking. Cuvier has separated them into three sections: the first have the jaws naked, and they are of a small size; the second are fish of greater size, and have the under jaw scaled; and the third, of middling size and lively colours, have the head and jaws covered with scales similar to those of the body. The first we shall notice is a beautiful fish from the Mediterranean Seas, the 


\title{
LETTERED SERRANUS.
}

\author{
Serranus scriba.-CUv. et VAL.
}

\section{PLATE XVII.}

Perca scriba, Linnceus._Le Serran ecriture, Cuv. et

Valen. Hist. Nat. des Poissons, ii. p. 21 j.

D. 10.14 ; A 3.7 ; C. 17 ; P. 13 ; V. 1.5 .

THis beautifully marked fish is found on the coast of Provence, Malta, and Naples, besides other parts of the Mediterranean. The general ground tint of the skin is a reddish orange, sometimes inclining to olive, and shading to a pale tint on the lower parts. The back is banded as in the perch, with dull brown bands which gradually lose themselves after passing the middle of the fish; but the most showy marks are the narrow irregular lines of rich blue which run on the nose below the eyes, and on the cheeks, which assume the forn of some written character, and which have given occasion to the name of scriba being applied to it. The ground colour of the fins, except the pectoral, is gray, spotted sometimes with reddish orange, and sometimes with purple. On the spiny part of the dorsal fin these marks take the form of a biotch or large spot, near the tip of each spine; but in the others they are disposed in transverse rows 


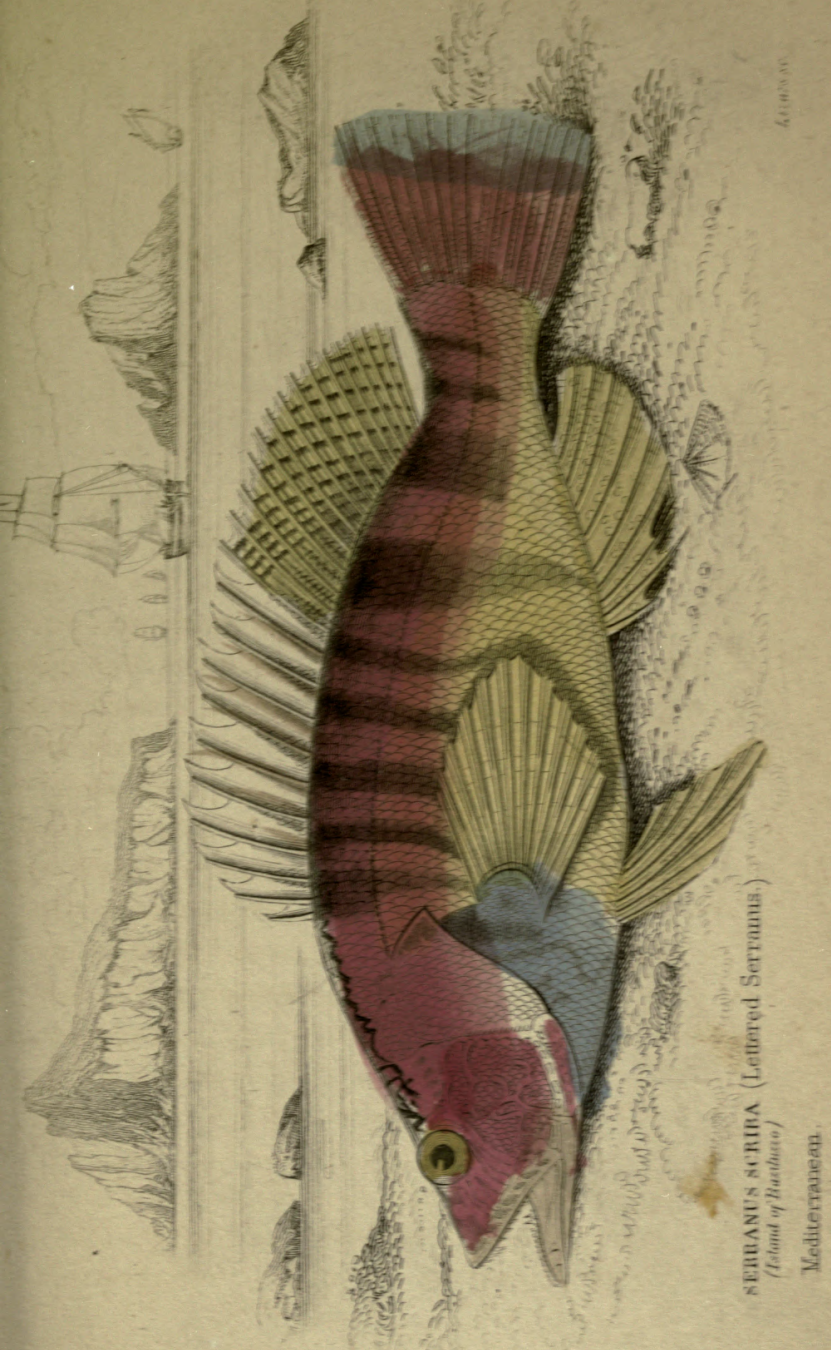


REESE LIBRA RY

UNIVERSITY

CALIFORNIA. 
upon the membrane, and have a regular appearance; the pectoral fin has the ground colour of a gamboge yellow.

These fish can never be seen in perfection, except when newly taken from the water; then their beauty is fresh and delicate, but in a few minutes it changes, even as soon as the fish dies, and the keeping for a day, or preservation in spirits, destroys all but the traces of where the delicate markings existed. They appear very different, also, according to their age, and the season at which they are taken. The present species scarcely ever exceeds half a pound in weight, and is to be seen in the markets at almost all seasons, being esteemed as an article of food. It feeds on small fish, and marine animals; but a species of cuttle fish, (Sepia octopoda,) is said to be among its most favourite prey, being even watched for, and the tentacula seized so soon as they are protruded from the hole where it is hid.

There is a circumstance in the economy of this fish, which merits observation, and even farther examination. It is asserted by Cuvier, who cites, in addition to his own observations, those of Cavolini, that the milt and roe are com bined in one individual, and that the fish are in fact hermaphrodites. The milt, or body supposed to be so, is placed at the lower part of each roe or ovarium, growing and increasing with that organ, 
and appearing small and imperfect at the season when the spawn was little advanced. Fish with a milt only, appear not to have been met with, and even among the ancients, to whom the fish was known, it was an accepted opinion, that females only existed.

Another Mediterranean species is the Perca cabrilla of Linnæus, distinguished from the last by the want of the inscription-like markings on the head, but having three or four oblique bands on the cheeks, and longitudinal stripes on the body, of a bright vermilion. It has also the deeper transverse bands on the body, bright spots and bands on the fins, and is altogether a fish of as great beauty as the preceding. It is commonly taken in the Mediterranean. A curious species from the north-west of New Guinea is described in the voyage of Frecynet, nearly white, with a black line running along the centre; and another species is mentioned by Cuvier, which has the skin which covers the preopercle nearly without scales - the Serranus gymnopareius.

Our next fish represents the form of Cuvier's second division of this great genus, with the head and jaws strongly scaled, and called by him Barbier; except in this character, they are nearly allied to the last. 


$$
\begin{gathered}
\text { REESE LIBRARY } \\
\text { OF THE } \\
\text { CAIVITITIT } \\
\text { CALIFORNIA. }
\end{gathered}
$$




\title{
135
}

\section{THE SPINED SERRANUS.}

\author{
Serranus anthias._Cuv. et VAL.
}

\section{PLATE XVIII.}

Anthias primus, Rondoletius. - Labrus anthias, Linnaus-

Le Barbier de la Mediterranée, Cuv. et Valen. Hist. Nat. des Poissons, ii. p. 250.

$$
\text { D. } 10 \text { or } 11-1.5 ; \text { P. } 17 \text {; V. } 1.5 \text {; A. } 3.7 \text {; C. } 17 .
$$

The colour of this beautiful fish is a brilliant red or scarlet, which, on the sides, assumes a golden tint, and on the belly becomes pale, or almost silvery. Upon the sides of the head are three bands of golden yellow, none of which pass the gill covers except the lowest, which reaches nearly to the insertion of the pectoral fin. On the forehead there are transverse bands of bronzed green, and at the base of the dorsal fin along the back there are ten or twelve small spots of the same colour. The fins are all tinted with red and yellow; the dorsal fin has a border of the latter colour. The spiny part of this fin has sometimes ten, sometimes eleven spines, very strong - the third exceeding all the others in length by nearly a half. It is from a supposed resemblance of a portion of this spine to a razor, that the French 
have applied the title of "Barbier." The ventral fins have the rays very long, reaching nearly to the middle of the anal. It is found every where in the Mediterranean, and is in many places abundant. In size, it never reaches a foot in length, and is most generally from five to seven inches.

There is little doubt of this fish being known to the ancients; and it was rendered sacred among the divers for marine productions, from the supposition that no formidable fish would approach its retreats. When caught by a hook, they were said to be immediately relieved by the rest of the shoal cutting the line with their sharp spine. A much larger fish has been confused with this, and has had attributed to it great prowess in destroying sea monsters, and wounding the fishermen when taken.

A Brazilian species is so similar as scarcely to be distinguished. It differs in the rays of some of the fins, thus, D. 10.12, and C. 3.6, and Cuvier has applied the name of $S$. tonsor. Another species placed in this division, but which does not agree entirely in all the characters of scaling about the jaws and head, has been named $S$. oculatus from the very large size of the eyes. The colour is a rich golden rose. It is found in the vicinity of Martinique.

We now come to far the most numerous division of this section, those which have the under 
jaw only covered with very small scales, to which Cuvier has given the name of Mérous. One of the largest of this division, the Perca gigas of Brunich, by the older ichthyologists was scarcely if at all known; and by those of the present day comparatively little, except that the form has been ascertained. It is a fish which attains to a weight of sixty pounds, and is sometimes taken when approaching the coasts in spawning time. It occurs in the Mediterranean, and is esteemed in some places for the table. The general colour is brownish, varying to a deeper shade, or tinted with more yellow according to age, and the body is clouded or marbled over with deep blotches of gray. Another species, reaching nearly an equal size with the above, was discovered by Geoffroy St Hilaire on the coast of Egypt; but it differs in the beautiful colouring with which it is adorned, being of a deep green, shading to white on the lower parts, and upon the back, sides, and fins, varied with markings of a clear and fresh tint of the same colour. It has been named Serranus aneus, Geoffroy. Some species from the Indian Seas are vory remarkable for the diversity and beauty of their tints. But the most remarkable fish which Cuvier has placed in this division is the 


\title{
$1: 38$
}

\section{LONG TAILED SERRANUS.}

\author{
Serranus phaton.-Cuv. et VAL.
}

\section{PLATE XIX.}

Le Mérou paille en queue, Cuv. et Valen. Hist. Nat. des Poissons, ii. 309. D. 9.11 ; A. 3.9 ; C. $14 ;$ P. 17 ; V. 1.5 .

THis fish has been figured from a specimen in the Jardin du Roi, where it exists without any note of its habits or native country. It is in length about six inches, and in its dried state is of a uniform dull tint. The singular character of this fish is in the tail, which has the two centre rays lengthened, and held together by a membrane which covers them like a sheath, and which extends into a narrow filament equalling the body in length. 


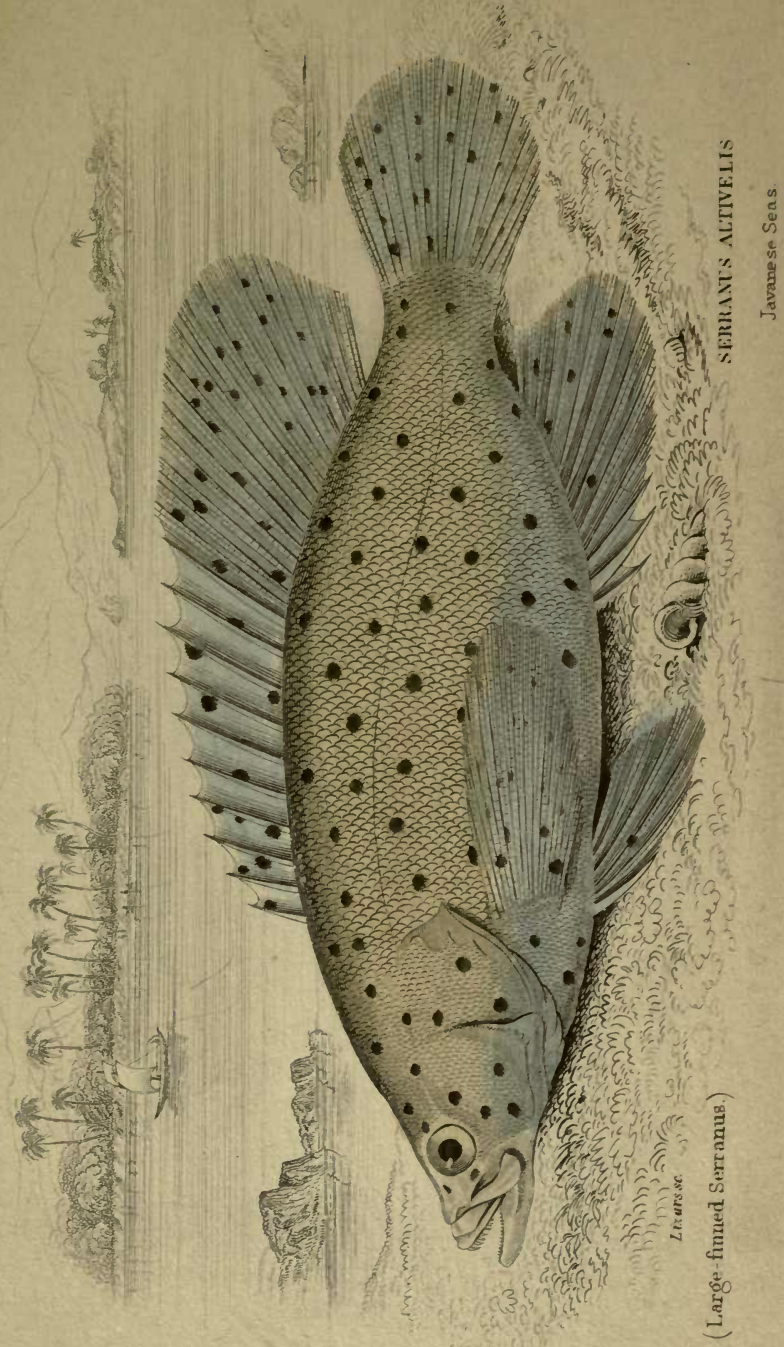




\section{REESE LIBRAAP
OF THE
UNIVERSITY
CALIFORNIA. \\ LARGE FINNED SERRANUS.}

Serranus altivelis._Cuv, et VAL.

PLATE XX.

Le Mérou à hautes voiles, Cuv. et Valen. Hist Nat. des

Poissons, ii. p. 324.

D. $10.19 ;$ A. 3.10 ; C. 17 ; P. 16 ; V. 1.5 .

This delicately coloured species is placed at the commencement of a group characterized by having markings on the body more or less spotted. The general tints are unobtrusive, being of a yellowish brown, the fins grayish, but relieved by the distinct spotting which is distributed over both. It is chiefly remarkable for the height and size of the dorsal fin, particularly the posterior or soft rayed part of it. It inhabits the Javanese Seas, but nothing farther appears to be known regarding it.

Cuvier still farther sub-divides the above section, by placing together all those Serrani which have the same distribution of spotted markings, but they become so very small as to be almost like points. One of the more remarkable with this colouring is a fish, also from the Javanese Seas, entirely of a fine red, or orange, spotted 
over with minute clear blue; the spiny part of the dorsal fin bordered with orange; the soft portion, and all the other fins, bordered with the same blue as that of the spots. It. will stand as the S. cyanostigma of Kuhl and Von Hasselt. Another equally so is the $S$. myriaster of Russel, of a brownish purple, and also covered with a thousand stars of transparent blue. Another curious fish is entirely of a brick red, with numerous white spots, and, in addition, is marked transversely with six bands of black, whence it has been termed $S$. sexfasciatus.

Before quitting this genus, or rather great division, it may be remarked, that in the lining, spotting, or banding, which so curiously and beautifully diversify the skins of these fishes, blue is one of the most prevailing colours. A half nearly are so marked, while it will be seen continued in the next fishes, (Plate XXII.) which Cuvier has placed in a small genus, and which, he remarks, he only separates for the sake of simplifying the nomenclature. This has all the characters of Serranus, but differs in having the edge of the preopercles, around and below the angle, divided into teeth, varying in size, directed obliquely forward, and somewhat resembling the teeth or points in the rowel of a spur, whence he has named the genus Plectropoma.* The scales * $\pi \lambda \tilde{n} x r \varsigma \circ y$, a spur; $\pi \tilde{\omega} \mu \alpha$, a covering. 
are small, ciliated, and stretch upon the base of the anal and dorsal fins. They are all natives of the warmer seas. This genus, though small, is again sub-divided into those which have the rising edige of the preopercle plain, or finely toothed. Belonging to the first is the 


\title{
LEOPARD-SPOTTED PLECTROPOMA.
}

\author{
Plectropoma leopardinus. - Cuv. et VaL.
}

\section{PLATE XXI.}

Holocentrus leopardus, Lacepede.-Le Plectropome leopard. Cuv. et Valen. Hist. Nat. des Poissons, ii. p، 392.
D. $8.11 ;$ C. $2.8 ;$ C. $15 ;$ P. 14 ; v. 1.5 .

IN this we see the continuation of the minute spotting of the last division of the Serrani. It is entirely of a yellowish brown, thickly covered on the upper parts with brown or reddish spots. It is from the Indian Seas, and reaches a considerable size.

In the second division, with the ascending edges of the preopercle finelv toothed, is the 


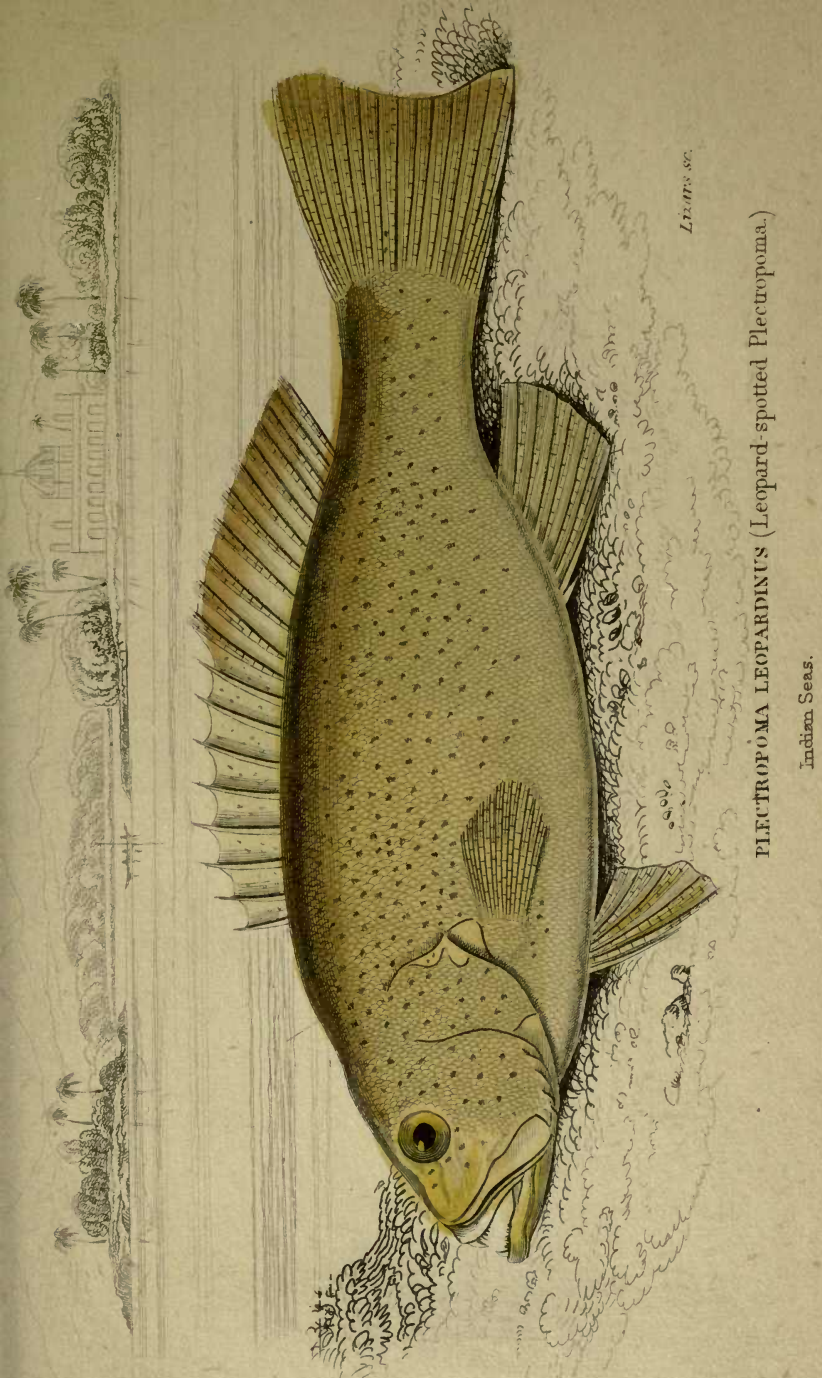




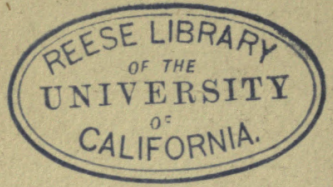




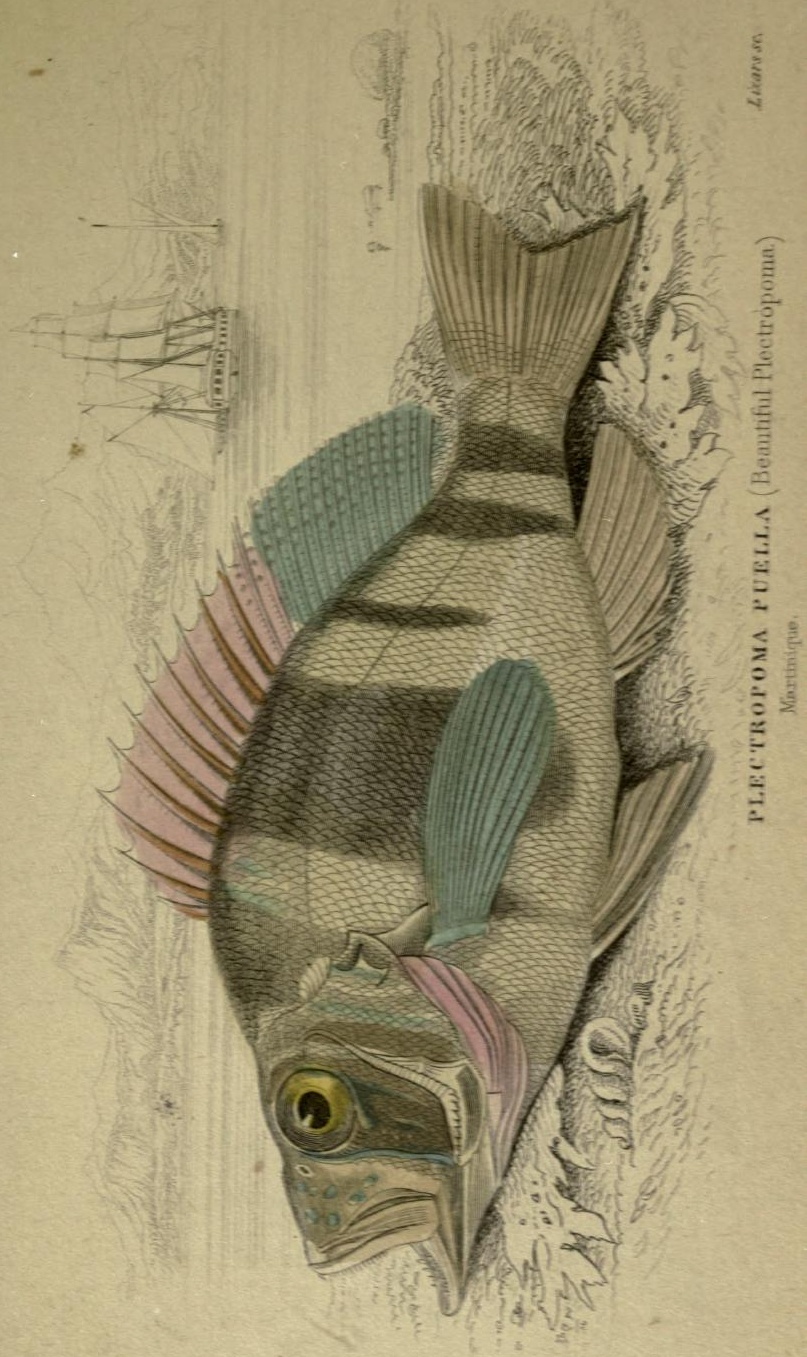




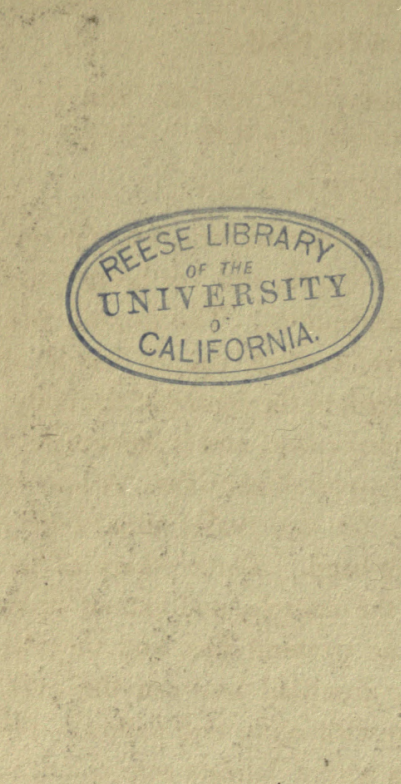




\title{
BEAU IFUL PLECTROPOMA.
}

\author{
Plectropoma puella._Cuv, et VaL.
}

\section{PLATE XXII.}

we plectropome demoiselle, Cuv. et Valen. Hist. Nut. des Poissons, ii. p. 405.

D. 10.16; A. 3.7; C. 17; P. 13; V. 1.5 .

THIs is a beautifully marked little fish of about four or five inches in length, and has been found in the vicinity of Martinique. The ground tint of the body is olive, crossed by six bands of violet black - the third, in the centre of the body, is very broad and conspicuous, and is immediately followed by one of narrow dimensions. A line of blue surrounds the orbit, and passes immediately before the first black band. Three others, of the same colour, cross the opercle, and extend upon the breast before the pectoral fins, and there is another line on the forehead between the eyes. The fins are tinted with olive and yellow - the pectorals sometimes with a delicate rose colour.

Other two species of this division only are known, the one also from Martinique, the other from Java; and from these we pass to another genus peculiar to the seas of India, named Diacope,*

- Araxoxì, division, slit. 
and which refers to a nitch or cut into the edge of the preopercle, into which is fitted a projecting tubercle. The mouth is furnished with teeth of considerable size, mixed with those which are concealed. Some species are of great beauty. The Diacope Sebre reaches a size of three feet in length, and is entirely of a yellowish tint, with three conspicuous bands of a deep and bright red. 


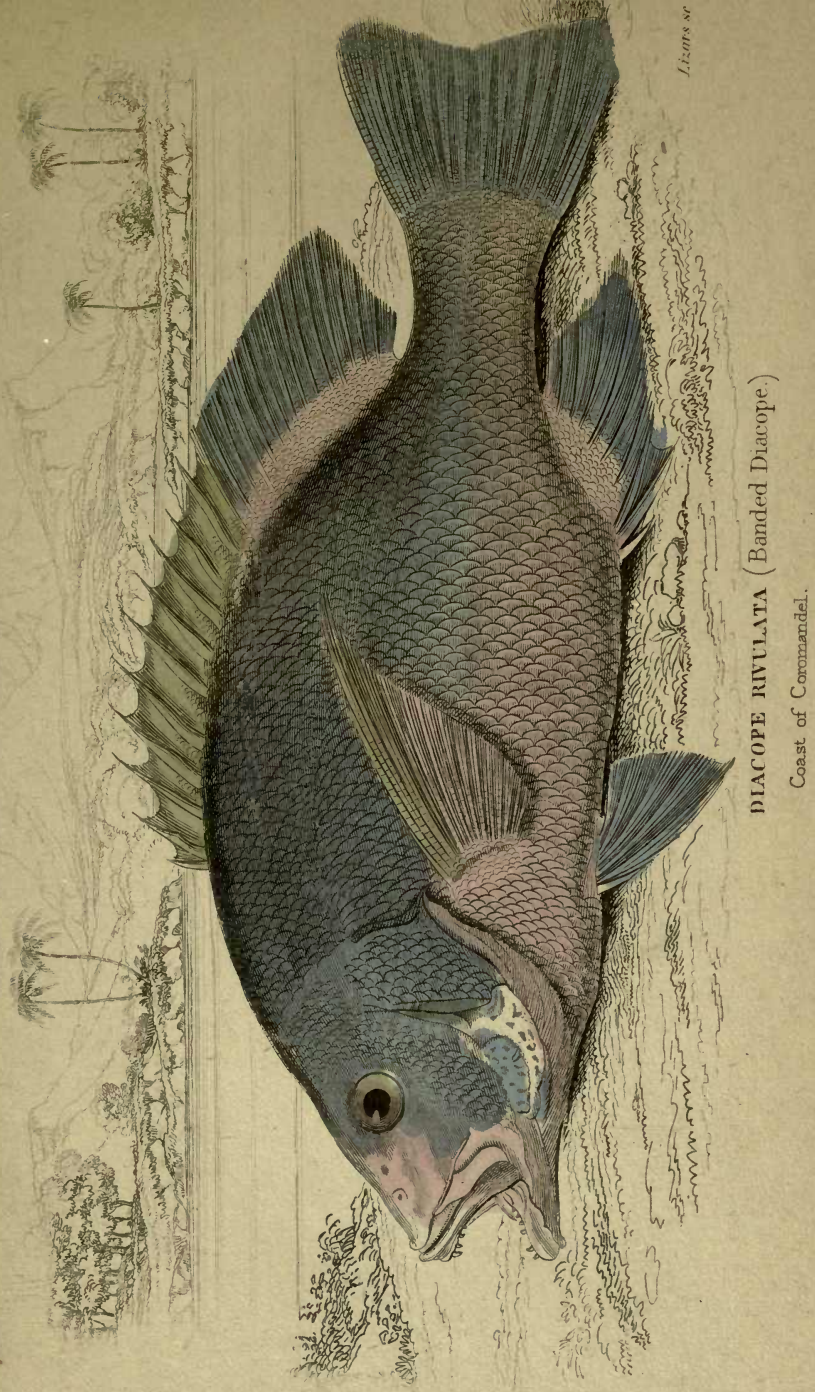




\section{REESE LIBRAPP
OE THE
UNIVERITY \\ CALIFORNIA.}




\section{BANDED DIACOPE.}

Diacope rivulata._CUv. et $\mathrm{VAL}$.

PLATE XXIII.

La Diacope a lines flexueuses, Cuv. et Valen. Hist. Nat. des Poissons, ii. p. 415.

D. 10.15 , or 16 ; A. 3.8 , or 9 ; C. $16 ;$ P. 16 ; V. 1.5 .

The Banded Diacope, found on the Coromandel coast, reaches a size of three feet and a half, is of a rich violet colour, changing to pink on the lower parts; on the opercles there are oblique lines; and on the head, and on each scale of the body, there are small dots of a clear blue, but which loses its delicate tint, and changes to white, soon after it has been removed from the water.

But one of the most gaudy is the $D$. octolineata, found near the Isle of France, in the Red Sea, and in the Pacific. The general tint of the body and fins is a rich reddish yellow, upon the belly nearly changing into white; upon the upper part of the body there are four longitudinal stripes of clear blue, marked with black dots ; and some- 
times the commencement of a fifth, where the yellow begins to shade into the white.

The $D$. macolor, described in Duperry's Voyage, is one of the most remarkable for contrast of colouring ; the upper part of the body is black, but relieved with large white spots, while the sides and belly are of a silvery white, interrupted by a black band. It is an inhabitant of the New Guinea seas.

D. sanguinea, Ehrenb. is a species from the Arabian Gulf, of a small size, and entirely of a rich red, so that among the considerable series of species which this genus embraces, we find a colouring equal in brilliancy to any of the Serrani, which are so remarkable for their fine tints. Different shades of red, with yellow and blue, are the prevailing colours; many of these fish are esteemed as an article of food, and from the large size of some of them, they may at some period yield a more profitable fishing, than, from their limited consumption, they do at present.

Another series of fishes have been separated from those under the name of Mescprion,* so named from having an arrangement of teeth in the centre of each side of the head in the form of a saw; they are closely allied to the last named

* pírov, middle; «provy, a saw. 
by the notch in the preopercle, and the tubercle or swelling in the inter-opercle. Many of them are of brilliant colours, and a considerable number are remarkable in having a conspicuous black mark upon the lateral line, placed generally not far from the tail. 


\section{ONE SPOTTED MESOPKIUN.}

Mesoprion uninotatus, Cuv. et FaL.

PLATE XXIV.

Le Mesoprion dore, Cuv. et Valen. Hist. Nat. des Poissons, ii. p. 449.

D. 10.12 ; A. 3.8 ; C. 17 ; P. 16 ; V. 1.5.

THE one spotted Mesoprion is a native of the American seas, and is one of the most beautiful; the back, upper part of the head, and cheeks, are of a rich steel blue; the lower part of the cheeks and sides of a rich rose colour, and the belly silvery ; the whole body is striped with seven or eight bands of a golden colour, on the dark part of the back irregular and disconnected. The dorsal fin has three yellow bands on a rose-coloured ground, and the others are gamboge yellow. The colouring is subject to considerable variety in tint, from golden orange to silvery. It seldom exceeds a length of thirteen or fourteen inches.

The members of this genus are of an elegant form, and are as remarkable for the richness and lustre of their colours as any of the preceding. They live solitary in the seas around the isles of India, China, and Japan, concealing themselves 


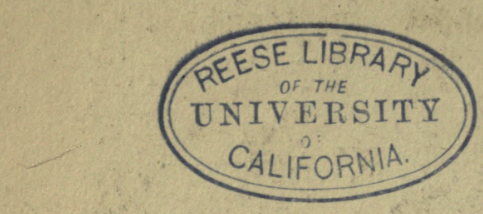


in the chinks and clefts of rocks, and only leave their dull retreats, in the finest weather, to prey on the tender molusca, with which these seas so thickly swarm.

Many of these fish attain a very large size and are much esteemed. Such is the $\boldsymbol{M}$. vivanus, reaching a weignt of forty pounds; and such also is the 


\title{
GOLDEN-TAILED MESOPRION.
}

\author{
Mesoprion chrysurus. - Cuv. et $\mathrm{V}_{\mathrm{AL}}$. \\ PLATE XXV.
}

Le Mesoprion a queue d'or, Cuv. et Valen. Hist. Nat. des Poissons, ii. p. 459.
D. 10.13 ; A. 3.9 ; C. 17 ; P. 14 ; V. 1.5 .

THIs fish reaches to a large size; it is of beautiful colours, but is subject to much variety in the depth of the rose and purple colours of the sides. Like the last, the upper parts are of a rich steel blue, tinged with green; the sides generally of a fine rose colour, tinged with golden yellow; the tail very much forked, and of a golden yellow. 


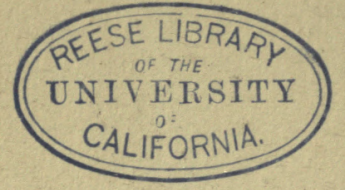




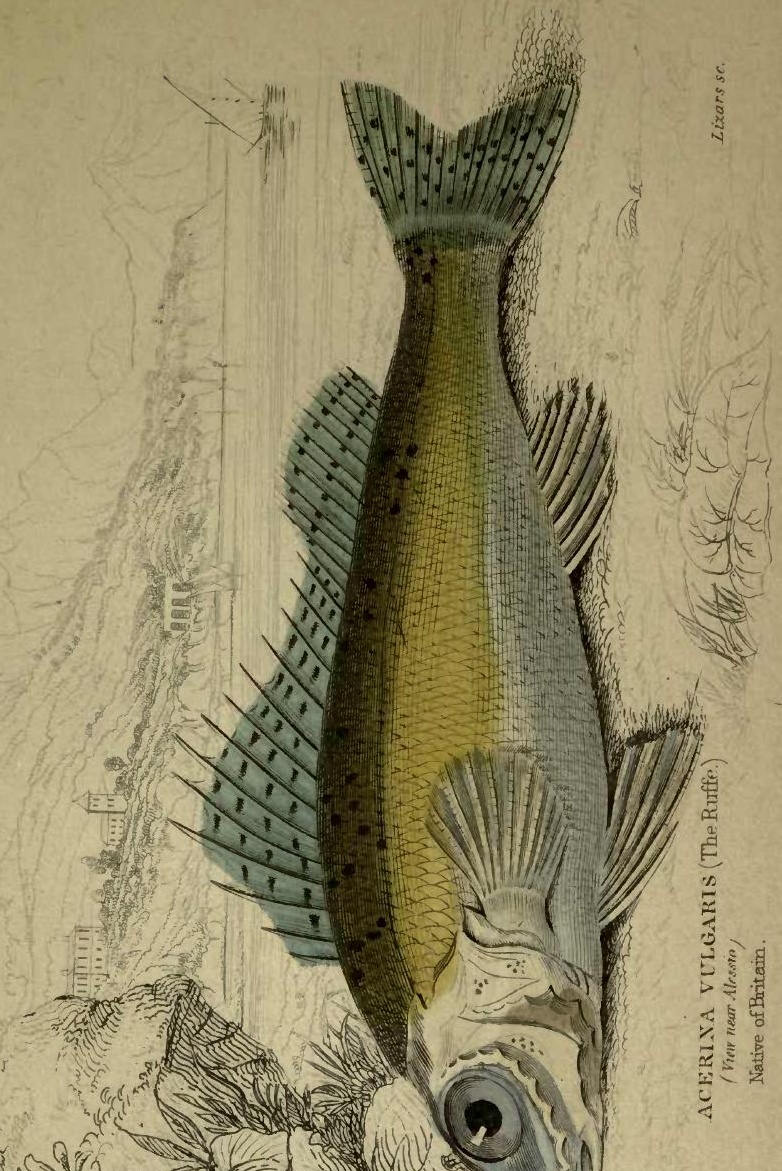

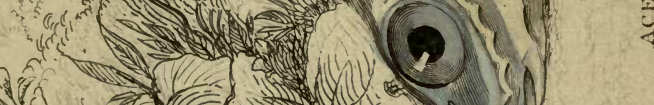
s.

1 है है।

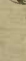
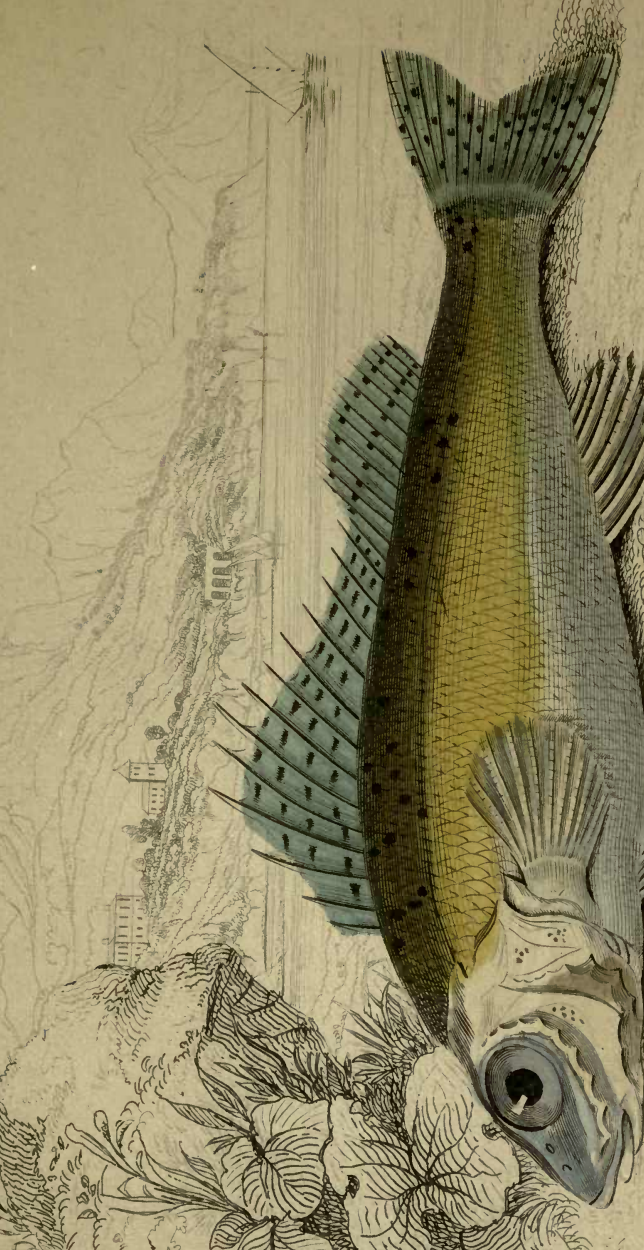

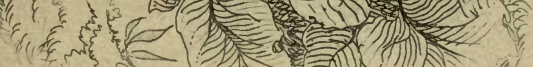
तु 2 , श्रा 1슨 
7,

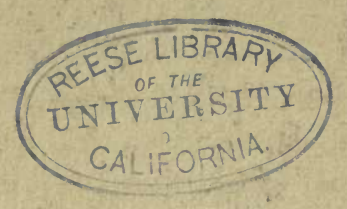$$
\text { RE E OF THE }
$$$$
\text { UNIVERSITY }
$$$$
\text { CALIFORNIA. }
$$ 


\section{THE RUTFE.}

Acerina cernua.

PLATE XXVI.

Perca cernua, Linnaus. - The Ruffe, Pennant, Donovan.

- La Gremille commune, Acerina vulgaris, Cuv. et Valen. Hist. Nat. des Poissons, iii. p. 4.
D. 14.12 ; P. 13 ; V. 1.5 ; A. 2.5 ; C. 17.

Wirn this beautiful little fish Cuvier commences his division of the "Percoid fishes," having a single dorsal fin, but with seven rays to the gill covers, and where the teeth are all equal. His first genus is Acerina, which differs from any of the preceding ones by the cavities in the bones of the cheeks and jaws. They all inhabit the fresh waters, and that now represented may be held as typical ; and, being a native of Britain, and abundantly dispersed over the lakes and rivers of northern Europe, will not be difficult to procure for examination.

The Ruffe is found in several of the English streams, - the Gare in Norfolk, the Birny in Merionethshire; and though not attaining a size above five or six inches, is much esteemed for 
the delicacy of its flesh. They are gregarious, are generally taken with the rod, in the same way that perch fishing is practised in the south, and in favourable davs six or eight dozen are taken at one stand. The coilours of the Ruffe are golden green, inclining to olive brown on the back, and silvery towards the belly, with clouded spots over the head and back. The spiny part of the dorsal fin is spotted with black on the membrane between the rays, the soft portion of it, and the tail upon the rays themselves. The lower fins are whitish, tinged with red. In the internal structure, it resembles the Perch. Two other species are found in the European rivers, one in the Danube, and another in the Don and Dnieper. The first, Acerina, Schraitzer, grows to a size of eight or nine inches, and is of nearly similar colour with that of Britain. The other is also somewhat similar, but is thickly spotted on the sides with black. Both are esteemed for their delicacy.

Following the Ruffes, Cuvier has placed the genus Polyprion, formed from a single species, common in the Mediterranean, remarkable for the large size it attains, and still more so for being long undescribed by ichthyologists. It is the 


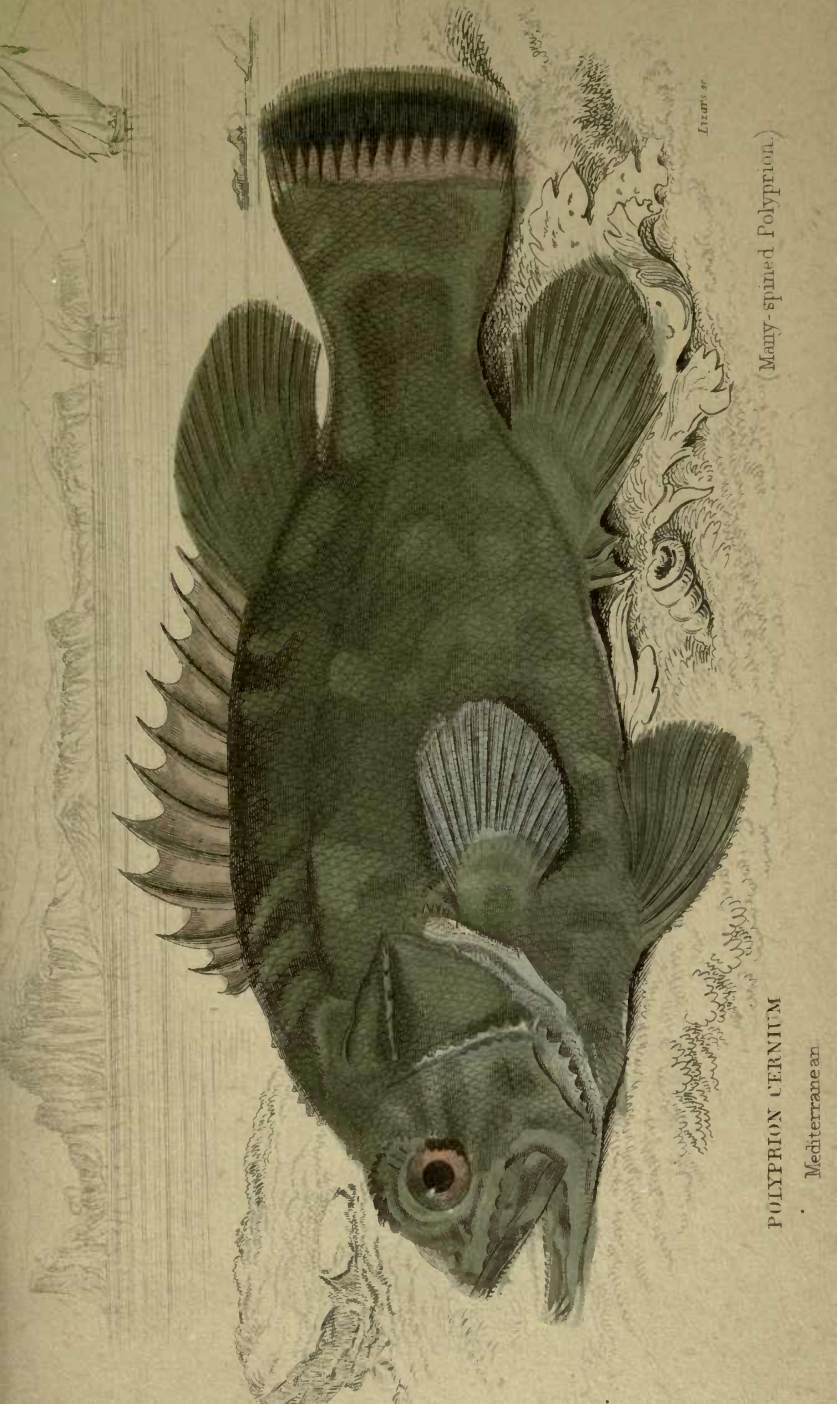




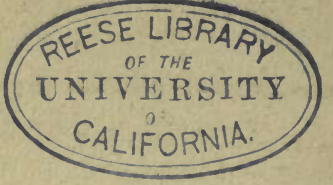




\title{
MANY-SPINED POLYPRION.
}

\author{
Polyprion cernium. \\ PLATE XXVII.
}

Valenciennes, Memoirs des Mus. xi.p. 265.

B. $7 ;$ D. 11.11 or $12 ;$ A. 3.8 or $9 ;$ P. 17 ; V 1.5 .

Tuis fish reaches a length of five or six feet, and sometimes a weight of one hundred pounds. The flesh is esteemed, being white, tender, and well tasted. It seems common in the Mediterranean from the accounts of MM. Risso and Valenciennes ; ${ }^{*}$ according to the former, it is frequent in the Sea of Nice, where it is found at so great a depth as three thousand feet, delighting in a rocky bottom. The head is slightly flattened, and strongly marked with numerous rugged protuberances on various parts. The preopercle is strongly and irregularly toothed, and a sharp ridge crosses the opercle from the upper articulation to the point, which is also sharp.

The colour of the old specimens is a uniform

* Memoirs des Museum, xi.p. 265. 
grayish brown; the tail bordered with whitish. The young are clouded with large irregular dark spots, on a grayish white or reddish ground. The flesh is white and well tasted. According to Forster, it is also an inhabitant of the Pacific Ocean.

Next to this is placed another singular fish, which we have represented in the vignette of the title page which accompanies this volume. It is the Pentaceros Capensis, a native of the Cape of Good Hope, and one specimen only is known in the collection of the Netherlands. According to Cuvier, its resemblance to the genus Ostracion of Linnæus is considerable, having the triangular form, and hard closely joined scales, and also the horns or protuberances which are seen in these fish; the line of the back is arched and bending, that of the lower parts nearly straight in the centre, but curved before and behind. The head and cheeks are strongly striated with rough granulated rays. In the centre of the bones of the nose, and on each side above the eyes, there is a compressed plate which rises in the form of a blunt horn; behind the cranium there is a sort of collar of seven plates. On the centre one, nearly in the middle of the neck, rises a third small protuberance, while on the two outside plates, which are analogous to the supra-scapulary bones, rises another, making in whole five horn-like eminences, 
whence the generic name has been derived. The spines of the first dorsal fin are very strong. The colours seemed a silvery yellow, or greenish, mottled with deep brown, and which latter tint occupied nearly the whole back. The length is about three inches 


\section{6}

\section{AMERICAN BLACK BAS\&.}

Centropristes nigricans._CUv. et VAL.

\section{PLATE XXVIII.}

Centropriste noir, Centropristes nigricans, Cuv. et Vulen.

Hist. Nat. des Poissons, iii. p. 37.

B. 7 ; D. 10.11 ; A. 3.7 ; C 7 ; P. $18 ;$ V. 1.5.

THIs fish represents the form of Centropristes of Cuvier, and very closely assimilates with the Serrani, having strong curved teeth. Here, however, the teeth are all fine, the opercle is spined, and the preopercle toothed like a saw; and there are no teeth to the suborbitary bones, as we saw in a preceding form, Acerina. The general form of the American Black Bass is rather lengthened. The colours in a dried or preserved state are, above, of a greenish brown, getting paler and of a yellowish tint on the sides and belly; but both these tints, according to observers who

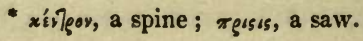




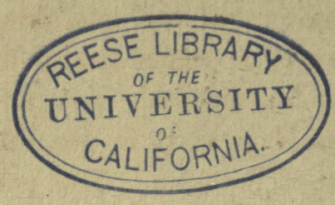$$
\text { REESE LIBRARY }
$$$$
\text { UNIVERSITY }
$$$$
\text { CALIFORNIA. }
$$ 
have noticed them in a fresh state, are of much greater brilliancy, the one being of a rich olive green, and the lower parts tinted with pink, as represented in the plate. These colours are only temporary, and fade with death. The dorsal fin is grayish, tinted with blue, and has three whitish transverse bands marked on the membranes between the rays. The other fins are also grayish black, and the tail and anal fin are irregularly spotted with a deeper tint of the same colour. The tail is remarkable in its form, projecting in the middle, where in general is seen the deepest part of the fork. The young are marked with clouded transverse bands.

This fish is abundant in the rivers of the United States, and is one of those most esteemed for the table. A few other species are natives of the American coasts ; one is found in the neighbourhood of Brazil, and two species, which differ somewhat in their characters, were discovered by MM. Guoy and Gaymard, in the New Holland Seas. These have for the present received the title of $\boldsymbol{C}$. scorpenoides and $\boldsymbol{C}$.truttaceus.

To the next form has been applied the name of Growler, Grystes. That which will represent it, is 


\section{8}

\section{THE SALMON-FORMED GROWLER.}

Grystes salmoides._Cuv. et VAL.

\section{PLATE XXIX.}

Le Growler Salmoide, Grystes salmoides, Cuv. et Valen.

Hist. Nat. des Poissons, iii. p. 54.

D. 10.13 or 14 ; A. 3.11 or 12 ; C. 17 ; P. 16 ; V. 1.5 .

Growler is the provincial American name for this fish, which Cuvier thinks has been given from some noise or croaking sound uttered by it. Two fish only have yet been discovered which will rank under its character; the present, a native of North America, and another procured from the New Holland Seas. In form of the body they somewhat resemble the last, but are at once distinguished from them and the preceding forms we have seen, by the smoothness and the want of any covering upon the head; the opercle and preopercle having neither spines nor teeth on their margins.

The present species, a native of the North American rivers, and abundant in the neighbour- 
3)

कीज 10 if

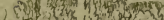

Gim

ज)

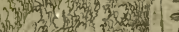

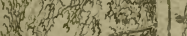

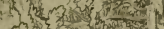

$33^{3}, 3$, n

3) 333 .

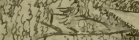

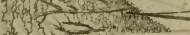

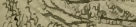

(3) 331 s)

37 (2)

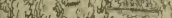

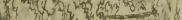

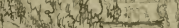

hin

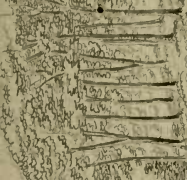

(3) का

a $x^{4}$

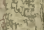

and

$\rightarrow$ 에

4. $2, x^{2}$

(4) $=-7$

sid

Ex

$-\frac{8 x}{4}$

- $2 x$

(4),

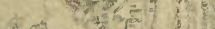

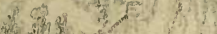

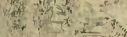

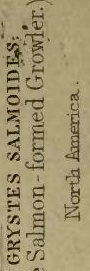

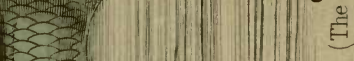

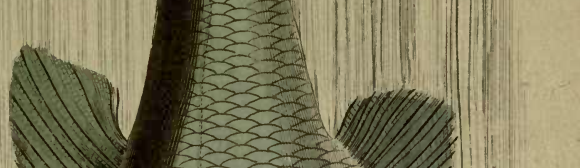
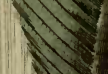

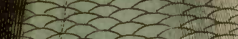
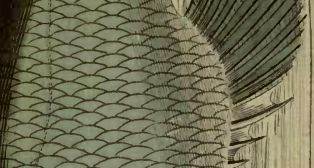

IN

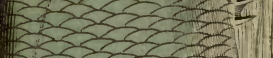
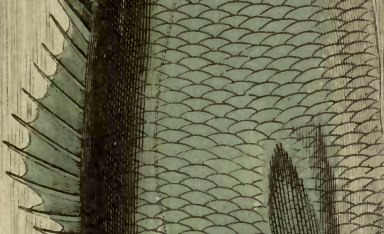

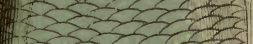

y.

-

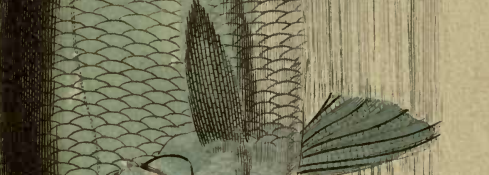

1. 1 -
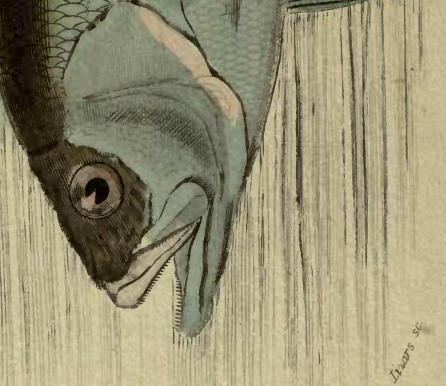
REESE LIBRA

UNIVERSITY

CALIFORNIA. 
hood of New York, has been named Salmoides, from its resemblance to the Salmon or Trout, being in some parts termed "Trout." It reaches a length of two feet, is of excellent flavour, and is much esteemed as an article of food; and it also affords sport to the angler, taking the hook eagerly. The general colours will be best seen from the plate, an unobtrusive tint of olive lightening towards the under parts, where it becomes grayish white. The first dorsal fin is weaker in proportion than most of the forms we have already seen, but the last rises high behind, and assumes a shape somewhat like that of some of the Greylings. The tail is shaped a good deal like the Salmonida, and in this fish has a dark bar across the centre.

The New Holland species is found in Macquary river, and in form resembles the common Perch, but the bony opercle is furnished with a very slight pointed spine. The colour of the preserved specimens was a greyish violet, paler beneath, with irregular blackish clouded spots.

The next of Cuvier's forms is 


\section{THE BRAZILIAN RYPTICUS.}

Rypticus arenatus. - Cuv, et VAL.

PLATE XXX.

Le Savonnier sable, Rypticus arenatus, Cuv. et Valen. Hist. Nat. des Poissons, iii. p. 65.
D. 3.26 ; A. 14 ; C. 15 ; P. 14 ; V. 1.5 .

These fish are characterized by having very minute scales, covered with an epidermis; by the dorsal fin having but a very small number of spiny rays, and in its not being notched or having any distinction between the spined and soft rayed portions. Both the opercle and preopercle are spined, and are without any serrating or teeth on the edges. They have been named "Savonnier" by the French, from the soft soapy and unctuous matter with which the skin is lubricated, and which, when rubbed on the hands, has a feel similar to that of soap. The most common species is found in the seas of the western parts of America, and is of a length of eight or nine inches, and generally of a blackish violet colour. 


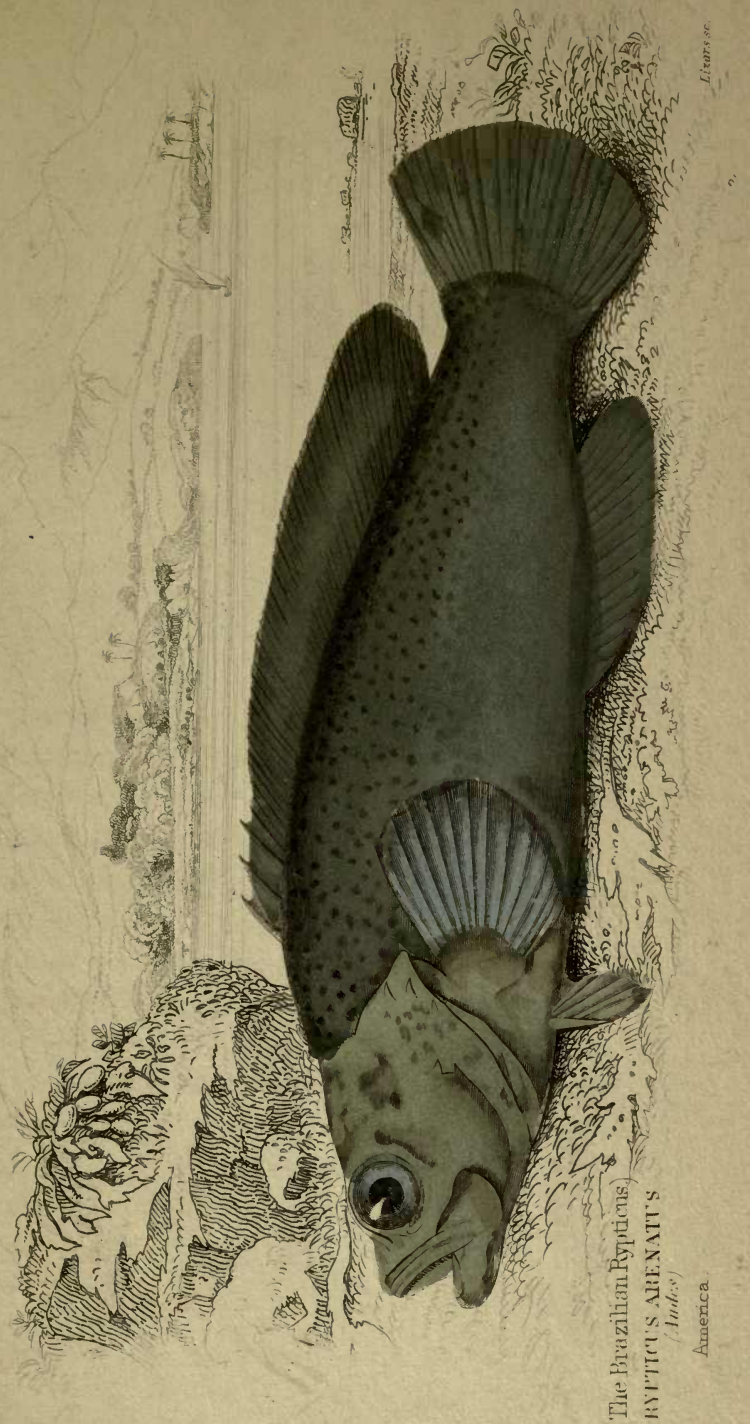




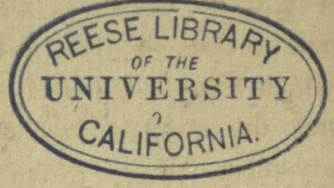


The second species, closely resembling the first, represented on the accompanying Plate $\mathrm{XXX}$, is found in the Brazilian Seas, and is of a greyish sandy colour, spotted over with small darker coloured specks.

This is the last form among the percoid fishes which we shall be able to illustrate in the present volume; and upon inspecting the table of genera, (page 89,) it will be perceived that nineteen additional forms remain, to which must be added other four, which Cuvier found it necessary to introduce after the construction of his table, leaving twenty-three, or nearly the half of this great family, unnoticed. In order to follow out our plan, and make each volume as complete as possible by itself, independent of its predecessors or followers, we shall shortly notice the remaining divisions of the family, and add one or two species which have been found in a fossil state. We shall proceed in the order of the table :-

The genus Cirrhites of Commerson, follows our last. The species approach nearest to Mesoprion, have the preopercle toothed on its rising edges, and the opercle terminated by a flat angle; but the character which distinguishes them is in the structure of the pectoral fins, which have the six or seven lower rays of each fin strong and lengthened beyond the others, without membranes 
between the projecting parts. Most of the known species are from the Indian Seas, though one or two have also been found in the South Pacific by the latest voyagers. C. fasciatus of Cuvier from the vicinity of Pondichery, will stand as a good example of this form, of a pale colour, but banded transversely with dull violet. The five lower rays of the pectorals are elongated.

The next is a genus which Cuvier formed after the construction of the table at the commencement of this volume, and which must be inserted. It is without canine teeth, and contains only one species Chironemus Georgianus.

The next two forms of the table are somewhat allied, and are both natives of America. The first, Pomotis, represented in the Pond Perch of the American rivers, is characterized by the prolongation of the opercle, from which Cuvier has formed his generic name, wishing to convey the idea of similarity to the ear. The most com- mon species is the Labrus auritus of Linnæus, being abundant in dams for mills, and the still waters of many parts of North America. It is of unobtrusive colours, but conspicuously marked with a large black spot, occupying the elongated angle of the opercle, and which is bordered above with white, below with reddish 
Aphredoderus, Lessueur. - Two edges of the suborbitary bones toothed, furnished with raised spines; edge of the preopercle toothed, the angle of the opercle with a spine; the anal fin without spiny rays. A single species only known-a native of the fresh waters of North America.

Centrarchus - has the preopercle entire, but the angle of the opercle is divided into two flat points. The most characteristic distinction, and that whence the name is taken, is in the anal fin having numerous spiny rays, amounting to five or six, while, in the other genera, they rarely exceed three. They are found in the fresh waters of North America. By Lacepede, they are placed in the genus Labrax, while, by the American ichthyologists, a genus has been formed entitled Cychla.

Priacanthus*-is distinguished by the scaling of every part of the mouth, jaws, and cheeks, in which they resemble Anthias, but they want the canine teeth, and have fine teeth on both jaws, a little tuft before the vomer, and a narrow line on each palatine bone. The posterior opening of the nostril is a large vertical slit; the lower angle of the preopercle is spined. Ten or eleven species

- Trichodon will be found in another place. 
are known, inhabitants of the ocean, and variously distributed. Many of them possess brilliant colouring.

Dules - resembles Centropristes, but has only six rays in the gill membranes. The opercle is spined. Several species are known, and there is a slight distinction in one portion having the dorsal fin perfectly entire, whereas the others have a slight notch or division between the spined and soft parts. An example of the first will be found in D. auriga, a native of the Brazilian Seas, so named, or by the French " cocher," from the third spine of the dorsal fin being much elongated, and supposed to resemble a whip. Of the other division, a species from Java will shew the form, D. maryinatus, a small fish, of delicate silvery colouring, and having the second dorsal fin tipped, and the tail doubly banded at the end, with deep black.

Therapon $\rightarrow$ has the anterior row of teeth upon the jaws stronger than the others. Before the vomer there is a single row, which fall with facility when touched. The dorsal fin is deeply cleft; the preopercle and suborbitary bones are toothed, and the opercle is terminated by a spine stronger than almost any other of the family. The swimming bladder is contracted in the centre, a 
circumstance not common among Cuvier's Percoid Fishes. The greater numbers are found in the Indian Seas.

Datnia-differs from the true Therapon in the form of the body being much broader, or the outline raised; the jaws pointed; no teeth on the palate, and in the spines of the first dorsal fin being extremely strong. Two species only are referred to this form by Cuvier-found in the rivers of India. The Caius datnia of Hamilton Buchanan, from the Ganges, will serve as an example.

Pelates - has the dorsal fin of a more equal size; the opercle with two weak spines, scarcely passing the membrane, and no teeth on either the vomer or palatine bones. Three species, from the New Holland Seas, seem all that are known, characterized by comparatively small scaling, and by the body being marked by longitudinal dark bands. Their discovery is due to MM. Lesson and Garnot.

Helotes - is distinguished principally by the outer row of teeth in the jaws being divided into three points. The preopercle is finely serrated, and the opercle has a single weak spine. Contains a species, discovered by Guoy and Gaymard in the 
New Holland Seas, $H$. sexlineatus, and characterized, like the last, by longitudinal bands of a deep colour.

Trichodon. - In this place Cuvier, in his Appendix, directs that Trichodon and Sillago should be placed. They vary from those immediately preceding in the dorsal fins being separated from each other, as in the first division of the family, and the first has a certain resemblance to the genus Trachinus. The preopercle has four or five very strong teeth or spines, and the opercle is finished by a flat plate; the skin is without scales. One species only is known, T. Stellerii, found on the coast of Kamtschatka, and particularly round the island of Unalaschka. It is well known to the inhabitants, who take them when burrowing in the sand like the Weavers. The females deposit their spawn in furrows of the sand, and are remarkable in being said to attend the young after they have been hatched.

Sillago - is of an elongated form, the mouth small, but the upper jaw rather protracted; the preopercle is toothed on its rising edge, and beneath bends under, so as almost to touch that on the opposite side when the animal is in a state of rest; the opercle is terminated by a single sharp point. The dorsal fins are separated from each 
other, and the first spine is often very much elongated. They are used as food, and in many places esteemed; they are found in the Indian, African, and New Holland Seas.

Myripristis - so named from having all the opercular bones and those of the cheeks minutely serrated, which distinguishes it from any we have yet seen. The dorsal fins may be said to be attached, though, in some instances, the first finishes and the second commences without any membrane appearing between them; the scales are all minutely dentated on the edges. The genus is most extensively distributed. In these fish, also, the ear is of a peculiar construction, there being a large oval opening, which is only closed by a membrane; into it the lateral lobe of the swimming bladder is fixed, which, with some similar structures, has given rise to the opinion, that this organ and those of hearing have relations which influence the latter. Several species are known.

Holocentrum - closely allied to the preceding, but furnished with a very strong spine at the angle of the opercle; the dorsal fins united; the third spine of the anal fin is remarkably strong; the swimming bladder is simple. The species are numerous, having a varied distribution, and 
they are generally of very bright and gaudy colouring.

Beryx - has many of the bones of the head serrated. The eye is extremely large, but the easiest seized character, in conjunction with the serrating on the head, is the form of the dorsal fin, placed near the centre of the body, and appearing single, without any interrupting notch ; the separation is only observable in the composition of the rays from spiny to pointed. Two species are described; one is from the New Holland Seas.

Trachichtys, Shaw.-Characterized by Dr Shaw from a single specimen found in the New Holland Seas. A single dorsal fin; the spines of this and the outer ones of the tail strong and rough; opercles with a large rough spine; the belly with large projecting plates. The whole fish remarkable tor the rugged nature of its covering - whence the name.

The arrangement of the next fishes depends upon the situation of the ventral fins, the dorsal being either double or single. The first have the ventrals placed on the throat or jugulum, or in advance of the pectorals. 
Trachinus - is of a lengthened form, having the first dorsal fin short, and capable of deflection; the second lengthened, and with numerous rays. The anal fin stretches nearly the whole length of the body; the opercle is spined; the eyes placed near the horizontal surface of the head. They inhabit the European Seas, and are well known to the fishermen for the wounds inflicted by the spines of the first dorsal fin.

Percis.-Closely allied to the last. The head more depressed. The dorsal fins completely united; spine of the opercle small. Several species from the Indian, African, and New Holland Scas.

Pinguipes. - Head more lengthened than in the last. The teeth strong, and slightly hooked, covered by fleshy lips; the dorsal fins connected, and regularly arching; the ventral fins very fleshy. Inhabits Brazilian Seas.

Percopis. - The form extremely lengthened. Dorsal fins distant; the teeth in the jaws strong and hooked; under jaw exceeding the upper in length; opercle and preopercle without teeth or spines. A single species discovered in the Brazilian Seas in the voyage of Frecynet. 
Uranoscopus. - The head disproportionally large and square; the mouth opening vertically; the eyes placed on the upper part of the head; the scapular bone furnished with a strong and rough spine; the dorsal fins united; the pectorals very large ; - these are the principal characters of this singular-looking fish. The swimming bladder is wanting, and the scaling is small. They are found in the European, Indian, and New Holland Seas, and exhibit some of the most grotesque forms among fishes.

The next fishes are distinguished by having the ventral fins placed immediately behind the pectorals.

Sphyrona.-Similar to Percophis in form. The teeth strong; the under jaw projecting; the dorsal fins widely separated, and both of five rays. - Esox sphyroena of Linnæus will serve as an example. Several species, chiefly from the American and Indian Seas. The Mediterranean species reaches a length of three feet. Several of the species are poisonous when eaten.

Paralepis. - Also of the lengthened form of the last. The under jaw elongated; but the form is chiefly characterized by the very backward 
position of the dorsal fins, both of which are small, the last with the rays extremely delicate. Three species known inhabit the Mediterranean, discovered by M. Risso.

Polynemos. - The head entirely scaled; the preopercle toothed; the scales easily deciduous; the dorsal fins far separated, and, with the anal fin, covered with scales; before the pectoral fins there are long filamentous appendages, varying in their numbers in different species. The species are numerous, and of varied distribution. Some are much esteemed for food.

The Mullets. - These fish, separated by Cuvier into two divisions, have been placed at the end of the Percoid fishes in an appendix, in a kind of indecision as to their proper station, but as nevertheless bearing a resemblance to them. They are distinguished by their separated dorsal fins, their large scales easily rubbed off, and by the filaments attached to the lower jaw. The first division is

Mullus, Linnæus. - Comprehending the farfamed "Mugil" of the ancients. Characterized by no teeth on the upper jaw, no spine on the operculum, and no air bladder. Three species are described by Cuvier, and in the Toura Italica of 
the prince of Musignano, other two are added. They all inhabit the Mediterranean Sea.

Upeneus, Cuvier. - Distinguished from the last by having teeth on both jaws, a spine on the opercalum, and furnished with an air bladder; the second dorsal fin is more ample and spreading. These are again divided into subordinate groups, the one having a narrow band of fine teeth upon each jaw, the other having a single row of separate conical teeth on each. They are natives of the Indian and American Seas.

Having thus exhibited, as far as we now can, the arrangement which MM. Cuvier and Valenciennes propose in the Percoid fishes, their first family, we may remark, that it forms a portion of the third order of the new system of Agassiz, the Ctnenoides. Several fossil forms have been discovered, some of which have been identified with the genera now existing, while others can be referred to no form which is at present known to ichthyologists. Here it would be impossible to enter into the details of this interesting part of the science, and we simply give an example of each, from the beautiful lithographic plates of Agassiz Poissons Fossils, which will illustrate the situation in which the parts of fishes have been preserved; and thence the difficulty 
which occurs to the student of fossils to trace, unravel, and restore the different parts of animals which apparently have so long since ceased to exist. The first is a species from the genus Lates, Cuvier, (described p. 101,) and of which a considerable number of species in a fossil state are already known; it is tire 


\section{Lates gracilis._AGASsIz. \\ PLATE XXXIII.}

So named from the apparently more than isualıy slender appearance of the body, notwithstanding the flattening which it may have received. It is from the calcareous schist of Monte Bolca, where it is found in great abundance. The scales are smaller than in any of the living species, but do not otherwise differ. Other two fossil species of this genus are also described from the same locality, one of which has yet only been found in this deposit, while a fourth, L. macrourus, is noticed from the vicinity of Sevres. Our second axample is the 


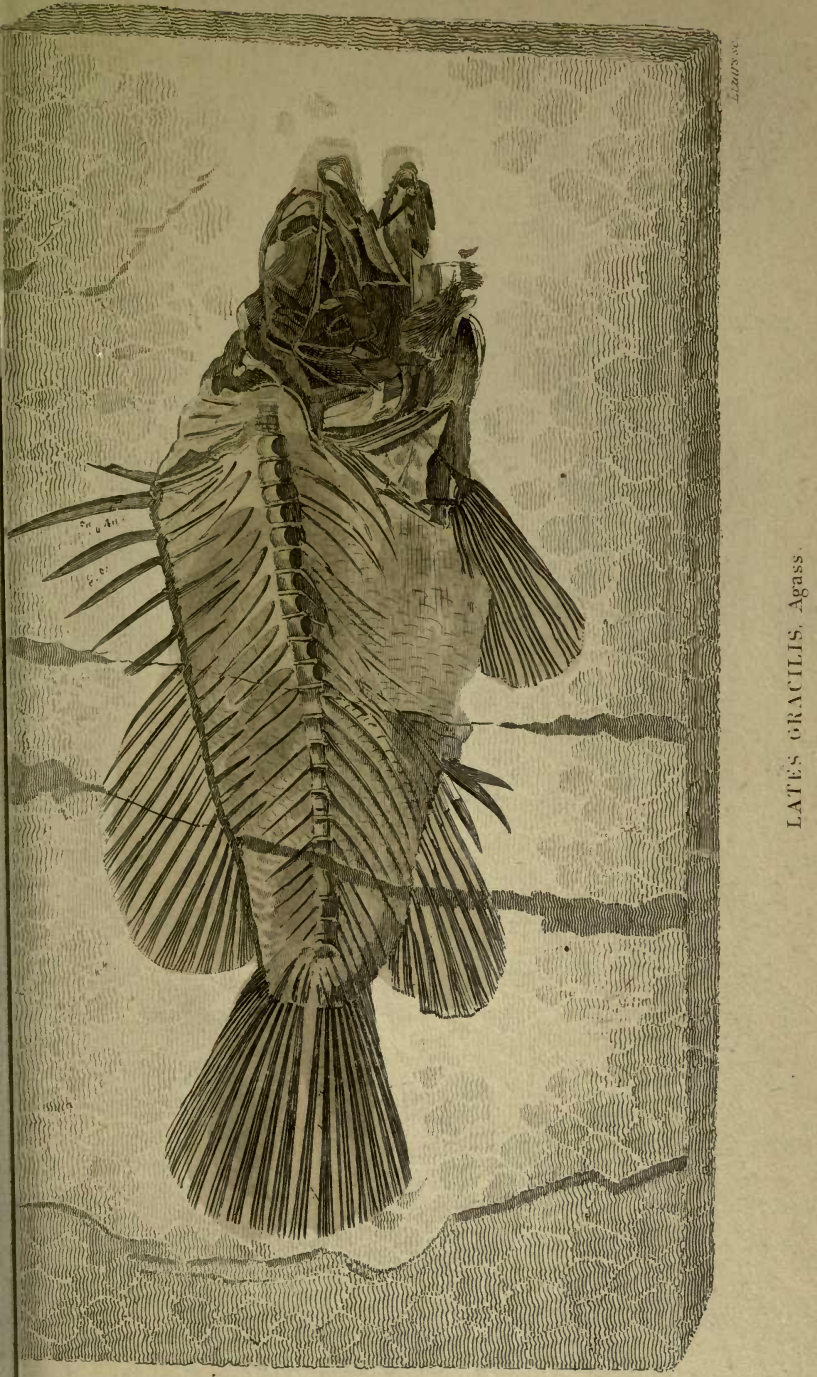




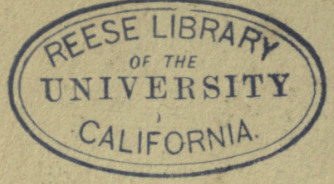




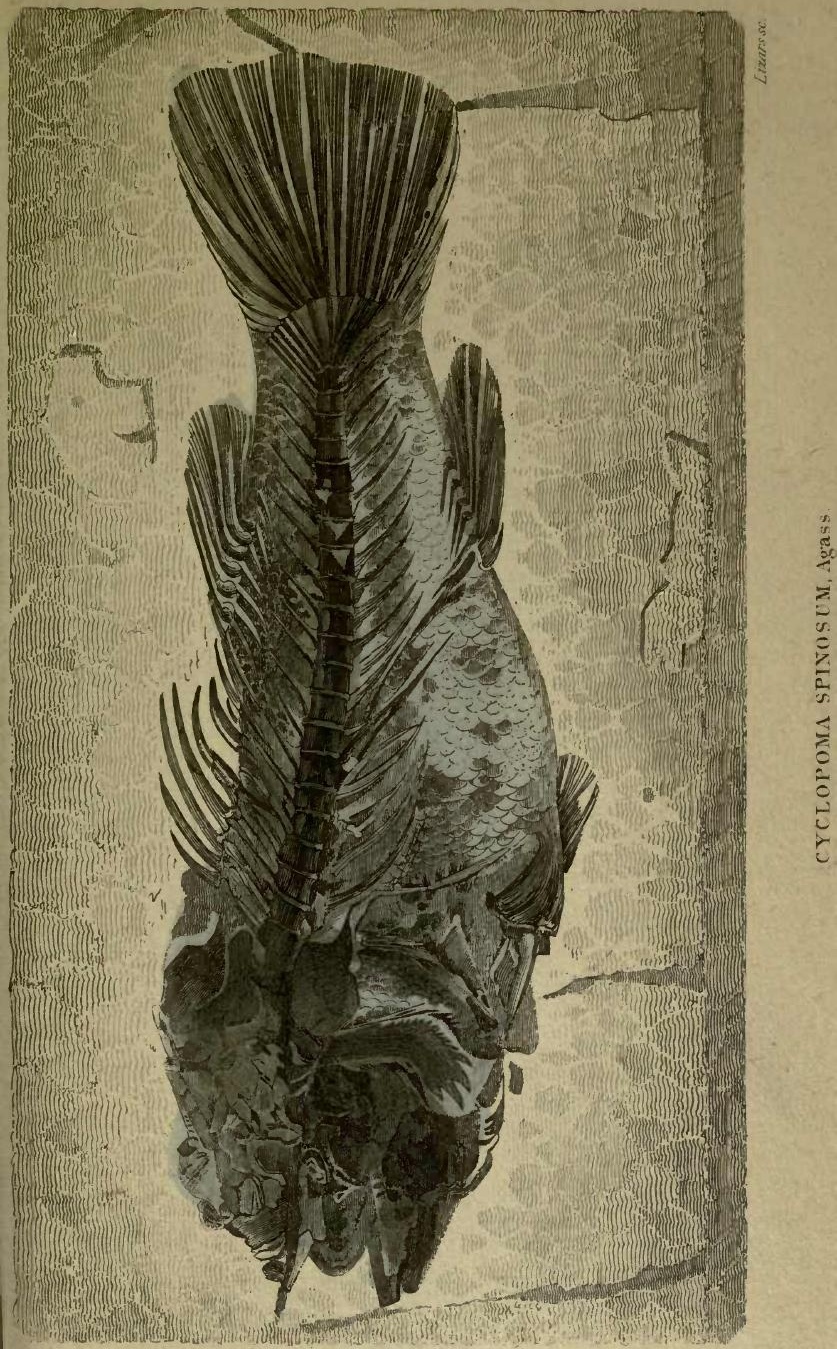




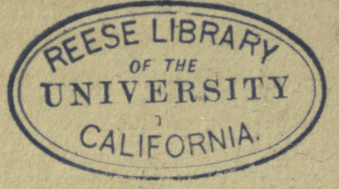


Cyclopoma spinosun. - AGASsIz.

PLATE XXXIV.

A genus formed for the reception of two species only yet found in a fossil state, and principally characterized by the very strong spine at the angle of the opercle, and the strong armatures of the preopercle, both of which are distinctly seen in the accompanying representation. Both species are from the schist of Monte Bolca.

Of the discoveries of fossil fishes, in the middle districts of Scotland, we hope to lay before our readers some particulars in another volume of this work. In the mean time, it may be remarked, that for a time it was believed that among the fossil fishes of the Edinburgh division of the middle district of Scotland, there were teeth, scales, and other parts of saurian animals; in short, that formerly we had, as natives of Scotland, creatures of the crocodile kind. It has lately, however, been proved, that these teeth and scales were parts of true fishes, and that hitherto no remains of saurian animals had been discovered 
in any of the quarries near Edinburgh, a view of the subject which was confirmed by the experience of Agassiz, while on his visit to Scotland during the meeting of the British Association, in September last. Upon an examination of the limestone quarries, the genus discovered to abound in them in the greatest profusion was Palconiscus, Agass.; and a new species has been named $P$. Robisonii, in honour of Mr Robison, secretary to the society which, by its endeavours, has rescued so many of these relics from destruction. Another fossil, entirely of a new genus, has been named Eurynotus creantus; and a third, the first which was discovered, has received the title of Pygopterus Bucklandii. The immense bony rays found in the same quarries are also referred to fish; and a new genus has been provisionally named Gyracanthus. The teeth, scales, and large bones, which gave rise to the idea that they belonged to a saurian animal, have been considered by Agassiz as sauraid, that is, resembling those of an animal of this kind not really belonging to it; and he refers them to some fish allied to Lepidosteus, which unites the characters of the crocodilean animals with those of fishes, and in an existing species of which that naturalist has lately been able to demonstrate, that the swimming bladder of fishes performed, to a certain extent, the office 
of a lung : thus resolving the question, which, at poge 61, we mentioned wasstill considered doubtful. To the animal to which these remains belonged, has been given the name of Megalichthys Hibbertii, and part of a second species has been discovered near Glasgow.

Many of our readers will, perhaps, exclaim that these are mere distorted masses, and that the idea of forming characters, or identifying the impressions with species at present in life, is but a pretence. Let them, however, examine before they decide, and we will guarantee that the interest of their researches will prevail. We would farther recommend the study to the young and enthusiastic naturalists of the present day, as one which will amply repay their researches, and where the fields of observation are neither far distant nor of difficult access. 


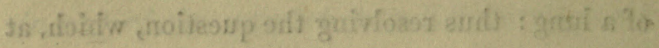

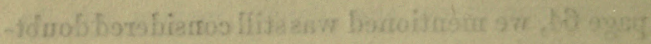

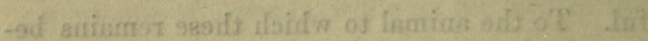

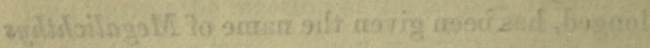

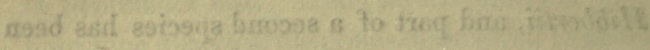

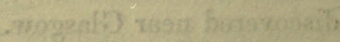

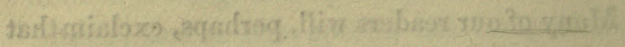

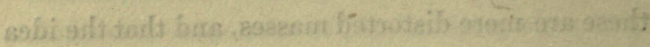

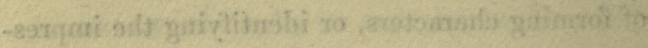

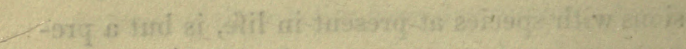

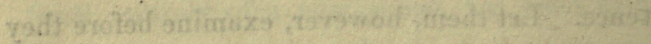

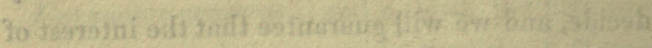

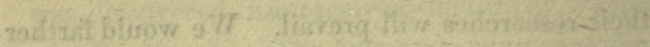

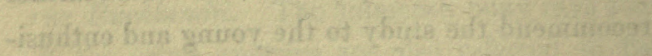
doich के

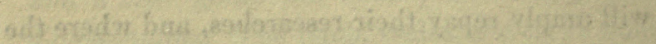

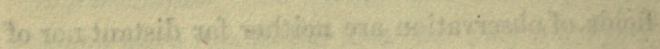

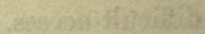


A P P ENDIX. 


$$
\text { X107 } 991
$$




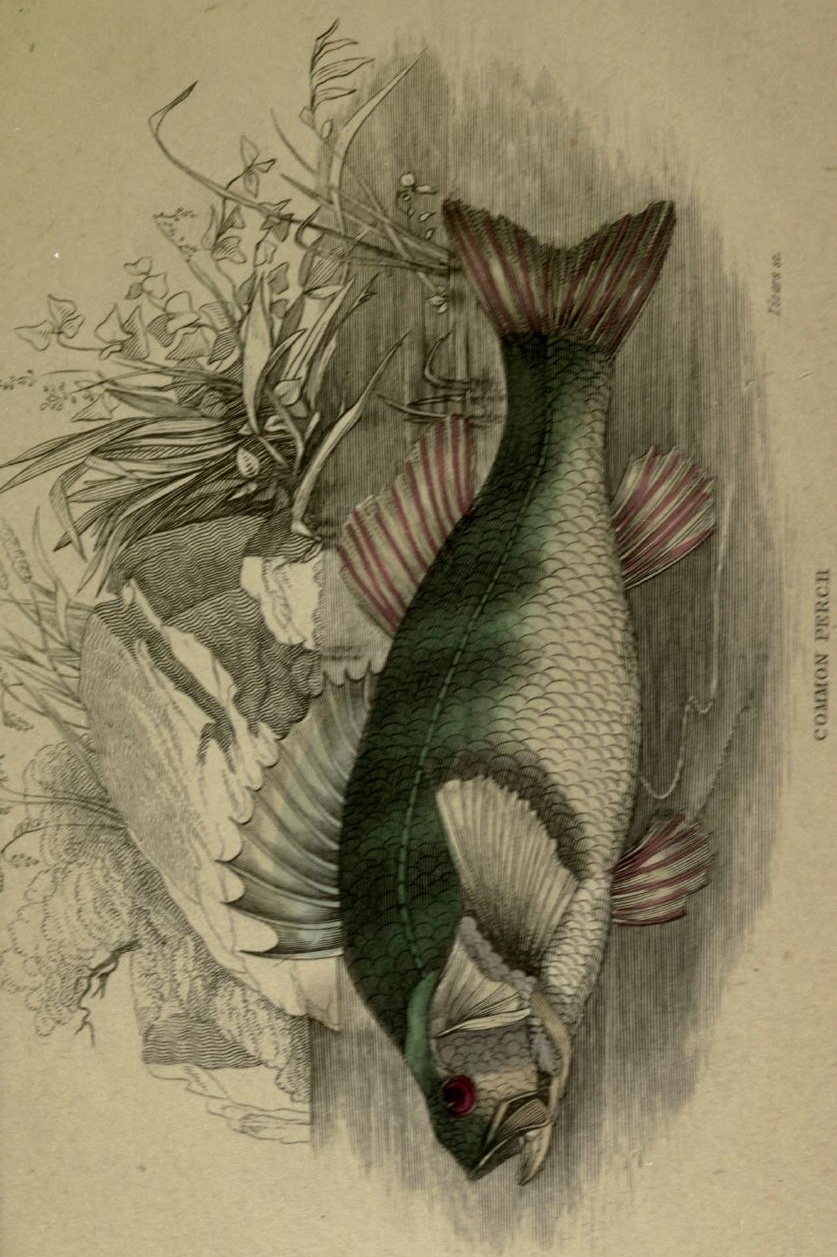




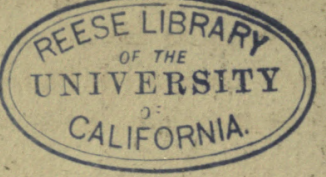




\section{APPENDIX.}

Extracts from the CoMPLETE ANGLER of IzaAK Walton, containing Observations on the Perch and Directions how to fish for him. With his Short Discourse, by way of Postscript, touching the Laws of Angling.

Piscator.-The Perch is a very good and a very bold biting fish. He is one of the fishes of prey, that like the pike and trout, carries his teeth in his mouth, which is very large: and he dare venture to kill and devour several other kinds of fish. He has a hooked or hog back, which is, armed with sharp and stiff bristles, and all his skin armed or covered over with thick dry hard scales, and hath, which few other fish have, two fins on his back. He is so bold, that he will invade one of his own kind, which the pike will not do so willingly; and you may therefore easily believe him to be a bold biter. 
"The perch is of great esteem in Italy," saith Aldrovandus: "and especially the least are there esteemed a dainty dish." And Gesner prefers the perch and pike above the trout, or any fresh water fish: he says the Germans have this proverb, "More wholesome than a perch of Rhine:" and he says the river perch is so wholesome, that physicians allow him to be eaten by wounded men, or by men in fevers, or by women in childbed.

He spawns but once a-year ; and is, by physicians, held very nutritive; yet, by many, to be hard of digestion. "They abound more in the river Po and in England," says Rondeletius, "than other parts; and have in their brain a stone, which is, in foreign parts, sold by apothecaries, being there noted to be very medicinable against the stone in the reins. These be a part of the commendations which some philosophical brains have bestowed upon the fresh water perch: yet they commend the sea perch, which is known by having but one fin on his back (of which they say we English see but a few), to be a much better fish.

The perch grows slowly, yet will grow, as I have been credibly informed, to be almost two 
feet long; for an honest informer told me, such a one was not long since taken by Sir Abraham Williams, a gentleman of worth and a brother of the angle that yet lives, and I wish he may : this was a deep-bodied fish, and doubtless durst have devoured a pike of half his own length. For I have told you, he is a bold fish; such a one as, but for extreme hunger, the pike will not devour. For to affright the pike, and save himself, the perch will set up his fins, much like as a turkey cock will sometimes set up his tail.

But, my scholar, the perch is not only valiant to defend himself, but he is, as I said, a bold biting fish : yet he will not bite at all seasons of the year; he is very abstemious in winter, yet will bite then in the midst of the day, if it be warm: and note, that all fish bite best about the midst of a warm day in winter. And he hath been observed, by some, not usually to bite till the mulberry tree buds; that is to say, till extreme frosts be past the spring; for, when the mulberry tree blossoms, many gardeners observe their forward fruit to be past the danger of frosts; and some have made the like observations of the perch's biting.

But bite the perch will, and that very boldly. 
And, as one has wittily observed, if there be twenty or forty in a hole, they may be, at one standing, all catched one after another; they being, as he says, like the wicked of the world, not afraid, though their fellows and companions perish in their sight. And you may observe, that they are not like the solitary pike, but love to accompany one another, and march together in troops.

And the baits for this bold fish are not many : I mean, he will bite as well at some, or at any of these three, as at any or all others whatsoevera worm, a minnow, or a little frog (of which you may find many in hay time). And of worms, the dunghill worm, called a brandling, I take to be best, being well scoured in moss and fennel; or he will bite at a worm that lies under cow dung, with a bluish head. And if you rove for a perch with a minnow, then it is best to be alive, you sticking your hook through his back fin; or a minnow with the hook in his upper lip, and letting him swim up and down, about mid-water, or a little lower, and you still keeping him to about that depth by a cork, which ought not to be a very little one. And the like way you are to fish for the perch with a small frog, your hook being 


$$
\text { FU.. } \triangle 1 E \text { PERCH. }
$$

fastened through the skin of his leg, towards the upper part of it: and lastly, I will give you but this advice, that you give the perch time enough when he bites; for there was scarce ever any angler that has given him too much.

[Although perch, like trout, delight in clear swift rivers, with pebbly, gravelly bottoms, they are often found in sandy, clayey soils : they love a moderately deep water, and frequent holes by the sides of or near little streams, and the hollows under banks.

The perch spawns about the beginning of March: the best time of the year to angle for him is from the beginning of May till the end of June, yet you may continue to fish for him till the end of September; he is best taken in cloudy windy weather, and, as some say, from seven to ten in the forenoon, and from two to seven in the afternoon.

Other baits for the perch are loaches, miller's thumbs, sticklebacks, small lob and marsh and red-worms, well scoured; horse beans boiled, cad-bait, oak-worms, bobs, and gentles.

Many of these fish are taken in the rivers about Oxford; and the author of the "Angler's Sure Guide" says, he once saw the figure of a 
perch, drawn with a pencil on the door of a house near that city, which was twenty-nine inches long; and was informed it was the true dimensions of a living perch.

The largest perch are taken with a minnow, hooked with a good hold through the back fin, or rather through the upper lip; for the perch, by reason of the figure of his mouth, cannot take the bait crosswise, as the pike will. When you fish thus, use a large cork float, and lead your line about nine inches from the bottom, otherwise the minnow will come to the top of the water; but in the ordinary way of fishing, let your bait hang within about six inches from the ground.] And now I think best to rest myself, for I have almost spent my spirits with talking so long.

Venator. Nay, good master, one fish more! for you see it rains still; and you know our angles are like money put to usury - they may thrive, though we sit still, and do nothing but talk and enjoy one another. Come, come, the other fish, good master!

Piscator. But, scholar, have you nothing to mix with this discourse, which now grows most tedious and tiresome? Shall I have nothing 
from you, that seem to have both a good memory and a cheerful spirit?

Venator. Yes, master! I will speak you a copy of verses that were made by Doctor Donne, and made to show the world that he could make soft and smooth verses, when he thought smoothness worth his labour; and I love them the better, because they allude to rivers, and fish, and fishing. They be these -

Come, live with me, and be my love, And we will some new pleasures prove, Of golden sands, and crystal brooks, With silken lines, and silver hooks.

There will the river whispering run, Warm'd by thy eyes more than the sun; And there the enamell'd fish will stay, Begging themselves they may betray.

When thou wilt swim in that live bath, Each fish, which every channel hath, Most amorously to thee will swim, Gladder to catch thee than thou him.

If thou to be so seen beest loth, By sun or moon, thou darkenest both; And if mine eyes have leave to see, I need not their light, having thee. 
Let others freeze with angling reeds, And cut their legs with shells and weeds, Or treacherously poor fish beset With strangling snare or windowy net;

Let coarse bold hands, from slimy nest, The bedded fish in banks outwrest; Let curious traitors sleave silk flies, To 'witch poor wandering fishes' eyes:

For thee, thou need'st no such deceit, For thou thyself art thine own bait: That fish that is not catch'd thereby Is wiser far, alas, than $I$.

Piscator. Well remembered, honest scnolar. I thank you for these choice verses, which I have heard formerly, but had quite forgot, till they were recovered by your happy memory. Anl because, as you say, our angles are as money put to use, that thrives when we play, therefore we'll sit still, and enjoy ourselves a little longer under this honeysuckle hedge. 
THE LAWS OF ANGLING.

Mr Good Friend - I cannot but tender my particular thanks to you, for that you have been pleased, by three editions of your Complete Angler, freely to dispense your dear-bought experience to all the lovers of that art; and have, thereby, so excellently vindicated the legality thereof as to divine approbation, that if I should go about to say more in that behalf, it indeed were to light a candle to the sun. But since all pleasures, though never so innocent in themselves, lose that stamp when they are either pursued with inordinate affections, or to the prejudice of another, therefore, as to the former, every man ought to endeavour, through a serious consideration of the vanity of worldly contentments, to moderate his affections thereunto, whereby they may be made of excellent use, as some poisons allayed are in physic; and, as to the latter, we are to have recourse to the known laws, ignorance whereof excuseth no man, and therefore, by their directions, so to square our actions, that we hurt no man, but keep close to 
that golden rule, "To do to all men as we would ourselves be done unto."

"Now, concerning the art of angling, we may conclude, Sir, that as you have proved it to be of great antiquity, so I find it favoured by the laws of this kingdom; for where provision is made by our statutes, primo Elizabeth, cap. 17, against taking fish by nets that be not of such and such a size there set down, yet those law-makers had so much respect to anglers, as to except them, and leave them at liberty to catch as big as they could, and as little as they would catch. And yet, though this apostolical recreation be simply in itself lawful, yet no man can go upon another man's ground to fish without his licence, but that he is a trespasser. But if a man have a licence to enter into a close or ground for such a space of time, there, though he practise angling all that time, he is not a trespasser, because his fishing is no abuse of his licence: but this is to be mderstood of running streams, and not of ponds, ct standing pools; for in case of a pond, or atnnding pool, the owner thereof hath a property in the fish, and they are so far said to be his, that he may have trespass for the fish against any one that shall take them without his licence, 
though it be upon a common, or adjoining to the kıng's highway, or adjoining to another man's ground, who gives licence. But in case of a river, where one or more have liberia piscaria only, it is otherwise; for there the fishes are said to be ferce naturâ; and the taking of them with an angle is not trespass, for that no man is said to have a property in them till he have caught them; and then it is a trespass for any to take them from him. But this is not to be understood of fishes confined to a man's own ground, by gates or otherwise, so that they cannot pass away, but may be taken out or put in at pleasure; for in that case the party hath a property in them, as in the case of a standing pool.

But where any one hath separalis piscaria, as in Child and Greenhill's case in Trin. 15, Car. I., in the King's Bench, there it seemeth that the fish may be said to be his, because no man else may take them whilst they are within his several fishing. Therefore what is meant by a several fishing is necessary to be considered. And though the difference between a free fishing and a several fishing be often treated of in the ancient books of the law; and some opinions will have the difference to be great, and others small. 
or nothing at all, yet the certainest definition of a several fishing is, "Where one hath the royalty, and owneth the ground on each side of the water ;" which agreeth with Sir William Calthorp's case, where an action was brought by hin against another for fishing in his several fishing, \&c.; to which the defendant pleaded, that the place wherein the trespass was supposed to be done, contained ten perches of land in length, and twenty perches in breadth, which was his own freehold at the time when the trespass was supposed to be done, and that he fished there as was lawful for him to do ; and this was adjudged a good plea by the whole court: and, upon argument in that very case, it was agreed, that no man could have a several fishing but in his own soil, and that free fishing may be in the soil of another man, which was all agreed unto by Littleton, our famous English lawyer. So that from all this may be drawn this short conclusion, that if the angler take care that he offend not with his feet, there is no great danger of his hands.

But there are some covetous rigid persons, whose souls hold no sympathy with those of the innocent anglers, having either got to be lords of 
royalties, or owners of lands adjoining to rivers ; and these do, by some apted clownish nature and education for the purpose, insult and domineer over the innocent angler, beating him, breaking his rod, or at least taking it from him, and sometimes imprisoning his person as if he were a felon. [There is no reading this passage without figuring to one's imagination the poor, humble, patient angler, standing still and defenceless, while the merciless lord of the manor is laying on him with a stick, perhaps the butt of his own rod, or a worse weapon. I will not dispute with the author, whether the meekness and stibmission of the poor fisher upon this occasion are very becoming or not: but this sort of passive valour is rather to be admired than imitated. Yet has the angler his remedy, as the reader will see a few lines below.] Whereas a true bred gentleman scorns those spider-like attempts, and will rather refresh a civil stranger at his table, than warn him from coming on his ground upon so innocent an occasion. It would therefore be considered how far such furious drivers are warranted by the law, and what the angler may in case of such 
violence do in defence of himself. If I come upon another man's ground without his licence, or the licence of the law, I am a trespasser, for which the owner may have an action of trespass against me: and if $I$ continue there after warning to depart by the owner, or his servant thereunto authorized, the owner, or his servant by his command, may put me off by force, but not beat me but in case of resistance by me, for then I, by resisting, make the assault; but if he beat me, I not resisting, in that case he makes the assault, and I may beat him in defence of myself, and to free myself from his violence. [Agreeable to the rule contained in this barbarous distich:-

Res dare pro rebus, pro verbis verba solemus, Pro bufis bufas, pro trufis reddere trufas.

Things must be recompenst with things, buffets with blowes, And words with words, and taunts with mocks and mowes.

DaLTox's Country Justice, chap. 72.]

And in case I shall leave my rod behind in his ground, he may take it damage feasant, but he can neither take it from my person by force, nor break it, but he is a trespasser to me; which seems clear by the case of Reynell and Champernoon, where Reynell brought an action of 
trespass against Champernoon for taking and cutting his nets. The defendant justified, for that he was seized in fee of a several fishing; and that the plaintiff, with others, endeavoured to row upon his water, and with the nets to eatch his fish ; and that, for the safeguard of his fishing, he took and cut the nets and oars: to which plea the plaintiff demurred, and then it was adjudged by the whole court, that he could not by such colour cut the nets and oars; and judgment was thereupon given for the plaintiff.

Doubtless our forefathers well considered, that man to man was a wolf, and therefore made good laws to keep us from devouring one another; and amongst the rest, a very good statute was made in the three-and-fortieth year of Queen Elizabeth, whereby it is provided, that in personal actions in the courts at Westminster (being not for land or battery), when it shall appear to the judges (and be so by them signified), that the debt or damages to be recovered amount not to the sum of forty shillings, or above, the said judges shall award to the plaintiff no more cost than damages, but less, at their discretion.

And now, with my acknowledgment of the advantage I have had, both by your friendship 
and your book, I wish nothing may ever be that looks like an alteration in the first, nor any thing in the last, unless, by reason of the useful pleasure of it, you had called it the Arcadia of Angling, for it deserves that title; and I would deserve the continuance of your friendship.

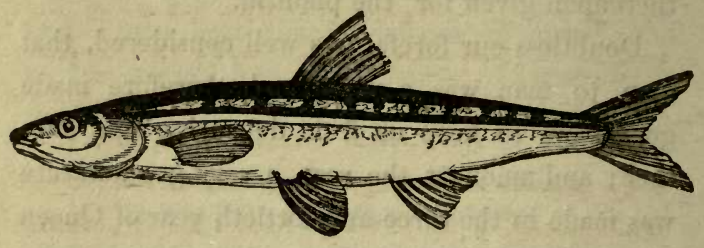


hoNtinuation of the discourse. BY SIR JOHN HAWKINS.

Since the writing the foregoing Discourse, the laws of this country, relative to fish and fishing, have undergone such alterations as would alone justify an addition to it; but as it has, of late, been objected to all laws that assign an exclusive right in any of the creatures of God to particular ranks or orders of men, that they savour of barbarism, and are calculated to serve the purposes of tyranny and ambition, it was thought necessary to trace the matter farther back, and show from whence laws of this kind derive their force. And though it is not imagined that speculative arguments will operate upon men of licentious principles, yet, as the general tenor of this discourse supposes the angler to be endued with reason, and under the dominion of conscience, it may not be amiss to state the obligation he is under to an observance of such laws, and to point out to him the several instances where he cannot pursue his recreation without the risk of his quiet.

Property is universally allowed to be founded 
on occupancy, the very notion of which implies industry, or some act in the occupant of which no stranger has a right to avail himself : he that first took possession of an uncultivated tract of land, provided it was no more than was necessary for the subsistence of himself and his family, became thereby the proprietor of such land.

Mr. Locke illustrates this doctrine by an elegant instance:- "The water running in the fountain," says he, "is every one's, but that in the pitcher is his who draws it." - On Government, book ii. chap. v. sect. 29 .

And, if this reasoning be admitted in the case of land, which is reckoned among the immoveable objects of property, it is much stronger in favour of things moveable, the right of which is at once claimed, and fortified by an actual possession and separation from that common mass in which they were originally supposed to exist.

But, notwithstanding the innumerable appropriations which, in the present civilized state of the world, appear to have been made, there are many things which may yet be said to be in common, and in a state of natural liberty; in this class we may rank creatures ferce natur $\hat{b}$, beasts of chase, many kinds of fowl, and all fish. The 
fisherman in Plautus admits, that none of the fish were his while they remained in their proper element, and insists only in his right to those which he had caught; Rudens, act iv. scene 3 . And both the Jewish and Roman lawyers assert, that wild beasts and fish belong only to those who take them.

This notion has led many persons to imagine that, even now, there subsists a general community of these creatures; and that, at this day, every one has a right to take them to his own use, wherever he finds them. Not to insist, that if all men promiscuously were permitted the exercise of this right, it would be of very little benefit to any, it may suffice to say, that there are few civilized countries that have not found it necessary, either for promoting some public good, or averting some public mischief, to control it by express prohibitions; and how far such prohibitions are deemed lawful and binding on the consciences of those on whom they are imposed, will appear by consulting Puffendorf, De jure Nat. et Gent. lib. iv. cap. 6 sect. 6 . Gudelin, De Jure novissimo, lib. ii. cap. 2. D. lib. xli. tit. 2. "De acquirend. vel. admittend. Possess." See also Garcilasso de la Vega, Comm. Reg. lib. vi. 
cap. 6 ; where it is said, that in Peru, hunting, by the inferior sort, is prohibited, lest, says tne author, "men betaking themselves to the pleasure of the field, should delight in a continued course of sports, and so neglect the necessary provision and maintenance of their families." And it is worth noting, that laws made to prohibit the taking of creatures ferce naturâ, by persons unqualified, do not take from a man any thing which is his own; but they barely forbid the use of certain methods of acquisition, which the law of nature might perhaps allow of.

Agreeable to the principles here laid down, we find that the laws of most countries, at least of this, have assigned the property in the creatures in question to particular persons. Thus to royal fish, which are whales and sturgeons, the king is entitled by his prerogative; and the property of fish in rivers, or, at least, a right to take them, is, in many places, given to corporations; as, with us, the fishery of the river Thames is granted to the city of London; and the townsmen of Hungerford, in Berkshire, claim a right of fishing in that part of the river Kennet, called their common water, under a grant from John of Gaunt, who, we may suppose, derived it from the crown: but 
in most instances fish belong to the owner of the soil.

These principles being recognized, and property once settled, it is easy to see the necessity and the justice of fencing it with positive laws. Accordingly, in this country, judicial determinations have, from time to time, been made, ascertaining the rights of persons to fisheries; and these, together with the several statutes enacted to prevent the destruction of fish, compose the body of laws relating to fish and fishing: the former, by way of supplement to the foregoing Discourse, are here laid down, and the latter will be referred to.

The property which the common law gives in river fish uncaught, is of that kind which is called special, or qualified property: which see defined by Lord Coke, in his Reports, part vii. fo. 17, b. and is derived out of the right to the place or soil where such fish live: so that supposing them, at any given instant, to belong to one person, whenever they resort to the soil or water of another, they become his property, and so in infinitum.

And to prove that this notion of a fluctuating or transitory property is what the law allows, we 
need only apply it to the case of the water in a river; which is so constantly passing from the soil of one to another, that no man can, in strictness, be said to go twice to the same river; and yet, by a grant of any quantity of land covered with water, which is the only legal designation of a river, not only a certain tract of the river, but the fish contained in it, shall pass. See Coke on Littleton, 4, a.

In the Register, a very ancient law book, we find two writs relating to fish: the one, for the unlawful taking of fish in a several fishery, and the other, in a free fishery. And of these in their order.

A several fishery is that which a man is entitled to in respect of his being the owner of the soil, and is what no one can have in the land of another, unless by special grant or prescription; and whoever shall fish in such a several fishery, without a licence, is liable to an action of trespass, in which the plaintiff may well demand "wherefore, in the plaintiff's several fishery, the defendant was fishing, and his fishes took," \&c., for though the fish be fera naturâ, yet being taken in the water of the owner of the river, they are said to be his fish, without saying in his soil, or 
water, 3d Coke's Reports, 553. Child and Greenhill's case; but he must set forth the nature and number of the fish taken, 5 Coke's Reports, 35. Playter's case, and 3d Coke, 18.

A free fishery is a right to take fish in the water and soil of another, and is derived out of a several fishery. If one seized of a river, grants, without including the soil, a several fishery, or, which amounts to no more than that, his water, a right of fishing passes, and nothing else. Plowden's Commentary, 154, b. Coke on Littleton, 4, b. And the word several, in such case, is synonymous with sole, and that in so strict a sense, that by such a grant not only strangers, but even the owner of the soil is excluded from fishing there. Co. Lit. 122, a. And farther, where one prescribes to have a several fishery in a water, which prescription always supposes a grant precedent, the owner of a soil, as much as a stranger, is liable to an action if he fishes there: 2 Roll. 258 , the case of Foriston and Catchrode in the Common Pleas. Mich. 29 and 30 Eliz. But here the writ shall vary from that in the case of a sever: fishery, and demand "wherefore the defendant, in the free fishery of the plaintiff at $\mathrm{N}$., without the licence and consent of the plaintiff, was fish- 
ing," \&c., expressing the nature and number of the fish taken: but because the soil does not pass by such a grant, and the fish are ferce naturâ, he shall not call them his fish, as in the former instance. See the case of Child and Greenhill, before cited.

The doctrine deducible from these principles is, that that which, united with the soil, would be a several fishery, when severed by grant, though the grant be of a several, or sole, and not of a free fishery, in terminis, becomes a free fishery.

There is yet another case that I shall mention, which will give the intelligent reader a clear notion of this matter. A man grants to one, or more, a liberty of fishing: here nothing but a naked right to fish passes, and the remedy against a trespasser is not severed from the soil; the owner whereof, and not the grantee, may maintain an action, and may also fish himself. Co. Lit. 122 a. [I find in Dudg. Warw. 1142, in margine, an account of the following grant, which for its singularity deserves notice. 31 Hen. III. "Thomas de Clinton, of Aminton. levied a fine to Phil. Marmion, that he and his heirs, his wife, and their heirs, might, when they 
came to Tamworth, or to their castle at Middleton, fish with a boat any where in his water of Aminton, with one net, called a fleu-net, and a tramil and sayna; for which liberty he gave him six marks of silver."]

As common of fishing may be appendant to land, so also there may be a joint tenancy, or a tenancy in common of a fishery. 1 Inst. $186 \mathrm{~b}$.

Having thus shown in what cases the angler, in the pursuit of his recreation, may become a trespasser, let us next consider how far he is, by taking fish, in danger of committing larceny; for that the taking fish out of a pond, without the consent of the owner, falls within my Lord Coke's definition of that crime, no one can doubt that reads it. His words are, "Larceny is, the felonious and fraudulent taking and carrying away, by any man or woman, of the mere personal goods of another; neither from the person nor by night in the house of the owner." 3 Inst. 107. And a little after, 109, he expressly says, " Larceny may be committed of fishes in a pond."

Now, though to make the taking any personal thing felonious, reason and the law require that the party should do it animo furandi (see Brace 
ton, lib. iii. fol. 150, Fleta, lib. i. cap. 36 , which we will suppose no angler to be possessed with), yet whether by the word pond, we are to understand ponds at large, is perhaps of some consequence for him to know.

It is a rule in law, that personal goods, and things severed from the freehold, shall go to the executors, and not to the heir.-Wentworth's Office of an Executor, chap. v. And so shall fish in a tank, or the like--Ibid. But Lord Coke, in his Commentary on Littleton, fol. 8, tells us, that fish in a pond shall go with the inheritance, " Because," says he, "they were at their liberty, and could not be gotten without industry, as by nets or engines."

From hence we may conclude, that fish in ponds cannot be said to be mere personal goods; and then it follows as a consequence, that of such fish larceny cannot be committed: and we may farther conclude, that the word ponds, in the above passage, must mean only stew-ponds, cisterns, or other such small receptacles of fish.

Many wholesome laws have from time to time been enacted, to prevent the destruction of fish; but they are so numerous, that I must refer the reader to the Statutes at large, or to the Abridg- 
ment published by a late worthy and learned friend of mine, John Cay, Esq., deceased.

He may also see, a Discourse on the Laws concerning Angling, and for Preservation of Fisn, at the end of the Angler's Sure Guide, written, as it seems, by the author of that book, with the learning and accuracy of an able lawyer. 


\section{CALIFORNIA.}



$: 7, t^{2}+2$

\section{Y OF CALIFORNIA LIBRARY}

\section{BFRNFT ER68\%}

LIBRARY OF THE UNIVERSITY OF CALIFORNIA

LIBRA
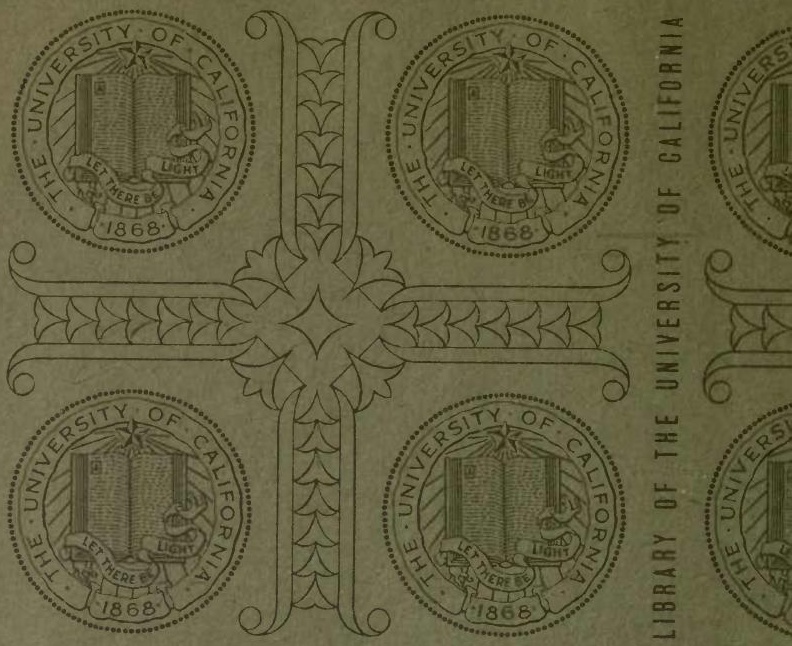

LIBRARY OF THE UNIVERSITY OF CALIFORNIA

LIBRAR
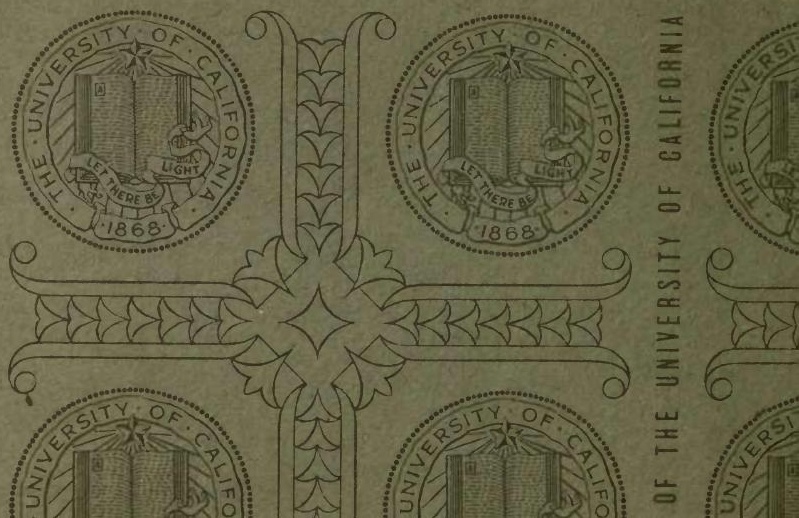


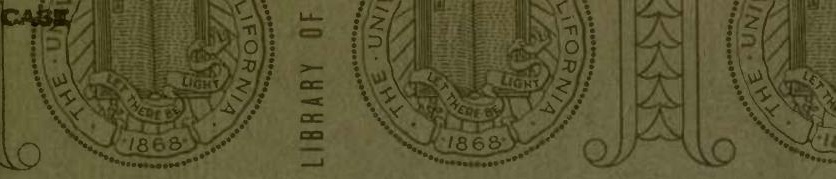

SITY OF GALIFORNIA

LIBRARY OF THE UNIVERSITY OF
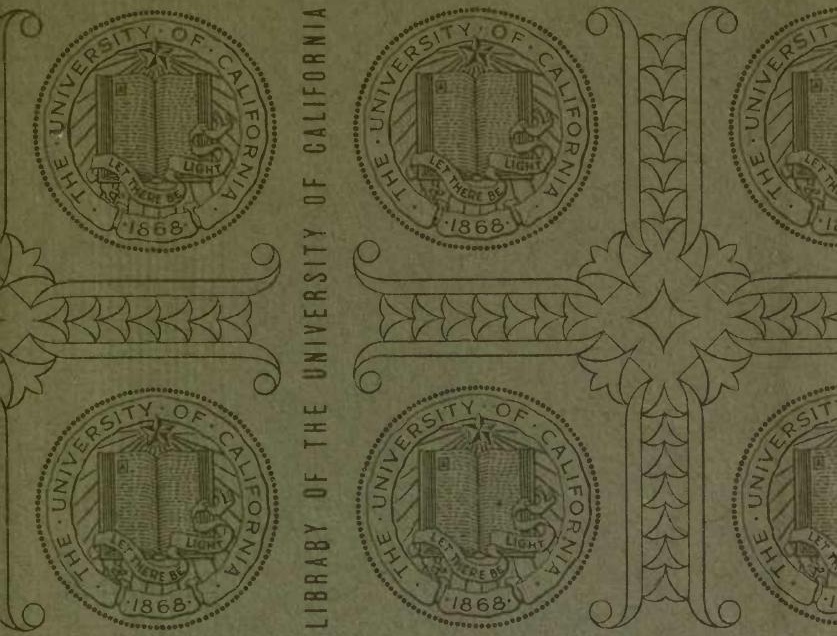

SITY OF CALIFORNIA

LIBRARY OF THE UNIVERSITY OF

Co

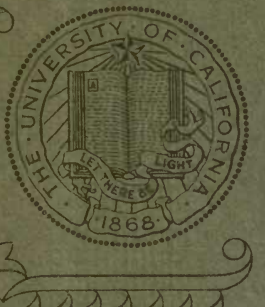

$\operatorname{lit}_{1}$

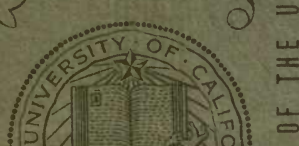

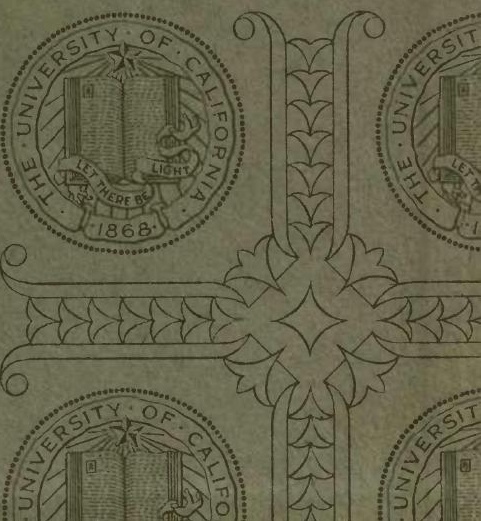


